Universidade de São Paulo

Escola de Enfermagem

VANESSA LOPES MUNHOZ AFONSO

AULAS VIRTUAIS NO CURSO DE LICENCIATURA EM ENFERMAGEM: OS ESTUDANTES COMO AUTORES

São Paulo 2014 


\title{
AULAS VIRTUAIS NO CURSO DE LICENCIATURA EM ENFERMAGEM: OS ESTUDANTES COMO AUTORES
}

\begin{abstract}
Dissertação apresentada ao Programa de Pós-
Graduação em Gerenciamento em Enfermagem da Escola de Enfermagem da Universidade de São Paulo para obtenção do título de Mestre em Ciências.
\end{abstract}

\author{
Área de Concentração: \\ Fundamentos e Práticas de Gerenciamento em \\ Enfermagem e em Saúde
}

Orientadora: Prof ${ }^{\mathrm{a}} \mathrm{Pr}^{\mathrm{a}}$ Cláudia Prado

Versão corrigida da Dissertação conforme Resolução CoPGr 6018. O original encontra-se disponível na biblioteca da EEUSP e também na Biblioteca Digital de Teses e Dissertações da USP (BDTD)

\section{São Paulo}


AUTORIZO A REPRODUÇÃO E DIVULGAÇÃO TOTAL OU PARCIAL DESTE TRABALHO, POR QUALQUER MEIO CONVENCIONAL OU ELETRÔNICO, PARA FINS DE ESTUDO E PESQUISA, DESDE QUE CITADA A FONTE.

Assinatura:

Data:

\author{
Catalogação na Publicação (CIP) \\ Biblioteca "Wanda de Aguiar Horta" \\ Escola de Enfermagem da Universidade de São Paulo
}

Afonso, Vanessa Lopes Munhoz

Aulas virtuais no curso de licenciatura em enfermagem: os estudantes como autores / Vanessa Lopes Munhoz Afonso.

São Paulo, 2014.

$146 \mathrm{p}$.

Dissertação (Mestrado) - Escola de Enfermagem da Universidade de São Paulo.

Orientadora: Prof. ${ }^{a}$ Dr. ${ }^{a}$ Cláudia Prado

Área de concentração: Fundamentos e Práticas de Gerenciamento em Enfermagem e em Saúde

1. Enfermagem 2. Educação em saúde 3. Educação à Distância 4. Tecnologia Educacional I. Título. 
Nome: Vanessa Lopes Munhoz Afonso

Titulo: Aulas virtuais no curso de licenciatura em enfermagem: os estudantes como autores.

Dissertação apresentada ao Programa de Pós-Graduação em Gerenciamento em Enfermagem da Escola de Enfermagem da Universidade de São Paulo para obtenção do título de Mestre em Ciências.

Aprovado em:

Banca Examinadora

Prof. Dr. Instituição:

Julgamento: Assinatura:

Prof. Dr. Instituição:

Julgamento: Assinatura:

Prof. Dr. Instituição:

Julgamento: Assinatura: 


\section{DEDICATÓRIA}

Aos meus dois amados filhos Caio César e Gabriel Gael, que neste momento estão no meu ventre, são a maior dádiva que eu já recebi e a razão do meu amor incondicional e felicidade.

Ao meu marido Júlio César, que sempre faz meu coração sorrir. Obrigada por ser meu companheiro em todas as aventuras dessa vida, meu porto seguro. Amo amor você!

Ao meu pai Wanderley, minha mãe Meire e meu irmão Leandro que sempre caminharam ao meu lado, que nunca mediram esforços para a realização dos meus sonhos, sempre com dedicação e amor incondicional. São os pilares da minha vida, a eles devo a pessoa que me tornei. 


\section{AGRADECIMENTO ESPECIAL}

Á minha orientadora e amiga Cláudia, por ser um exemplo de docente e uma fonte de inspiração. Sempre adorei trabalhar nos projetos ao seu lado...

Esse projeto de mestrado foi cheio de surpresas, mas eu tive seu apoio em cada pedacinho da caminhada e serei eternamente grata. 


\section{AGRADECIMENTOS}

Ás minhas colegas de mestrado que entre risos e choros me acompanharam nessa caminhada.

Aos docentes da EEUSP por tantos ensinamentos e por serem responsáveis pela profissional que sou hoje.

Aos funcionários da Secretaria de Pós-graduação por toda a ajuda fornecida quanto às questões administrativas.

Aos meus colegas de trabalho do IPGG pelo incentivo disponibilizado para que este projeto fosse concretizado.

À minha cachorrinha Wendy, que durante esses meses sentou pacientemente ao meu lado, com algum brinquedo na boca, e esperou o momento em que eu pararia de digitar e lhe daria atenção. 
Afonso, VLM. Aula virtuais no curso de licenciatura em enfermagem: Os estudantes como autores. [Dissertação]. São Paulo: Escola de Enfermagem, Universidade de São Paulo; 2014.

\section{RESUMO}

Introdução: A instrumentalização de docentes para o uso de Tecnologias Digitais de Informação e Comunicação (TDIC) aponta a perspectiva de uma prática inovadora e reflexiva, otimizando a qualidade do ensino e da aprendizagem em enfermagem. Objetivo: Descrever aulas virtuais construídas por licenciandos de enfermagem para a educação profissional técnica de nível médio em enfermagem. Método: Pesquisa exploratóriodescritiva, do tipo documental, desenvolvida na Escola de Enfermagem da Universidade de São Paulo (EEUSP), no curso de Licenciatura, na disciplina ENO 0336 - Seminários de Educação: Vivenciando o Processo de Educação na Enfermagem. A pesquisa teve como objetos de estudo 33 aulas virtuais inseridas na plataforma Moodle no ano de 2012. A coleta de dados ocorreu por meio da análise documental e o referencial teórico de análise seguiu o modelo do Design Instrucional Contextualizado (DIC). Resultados: Foram construídas 33 aulas virtuais pelos licenciandos e para cada uma delas a pesquisadora elaborou uma matriz de design instrucional, possibilitando uma visão ampla e elucidativa de como o futuro docente de enfermagem organizou o material didático no ambiente virtual. As matrizes foram compostas pelas categorias: objetivos, papéis, atividades, carga horária, ferramentas, conteúdos e avaliação da aprendizagem. Somente uma aula não continha os objetivos expressos, a maioria propôs níveis iniciais de conhecimento e compreensão, porém nenhuma atingiu os seis níveis sugeridos pela taxonomia de Bloom. Todas apontaram a presença do papel de apoio, relacionado à ação docente (o licenciando de enfermagem) e de aprendizagem (alunos da educação profissional técnica de nível médio em enfermagem, 
público alvo das aulas virtuais). Os licenciandos planejaram atividades diversificadas e criativas, tiveram como disparadores cognitivos atividades práticas relacionadas ao contexto social, acadêmico e de saúde do público-alvo. As atividades, de complexidade variada, contemplaram leituras de artigos, visualização de slides até a resolução de estudo de caso e pesquisa online. Na maioria das aulas o tempo estabelecido de 4 horas para realização das atividades foi respeitado considerando-se o número e a complexidade das mesmas. Foi utilizada uma ampla variedade de ferramentas como chat, quizz, fórum de discussão, glossário, biblioteca colaborativa, palavra-cruzada e vídeos, permitindo diferentes graus de interação entre os sujeitos. A busca por estabelecer um vínculo com o educando foi uma preocupação recorrente, seja por meio da criação de personagens animados, como os tutores virtuais, seja pela linguagem utilizada. Os licenciandos selecionaram conteúdos atuais e pertinentes aos estudantes e também produziram conteúdo online. Não foram observadas dificuldades técnicas na criação das aulas e os licenciandos demonstraram ampla capacidade de buscar conteúdos, carregar arquivos e disponibilizar informações, visto que são considerados fluentes digitais. A presença de critérios de avaliação, na maioria das aulas, indica a preocupação do licenciando em fornecer informações sobre como será mensurado o desempenho do aluno. Conclusões: A qualidade e a diversidade do material educacional produzido constituíram-se em um significativo acervo pedagógico, especialmente por ter sido produzido por educadores em formação. Agregar o valor da experiência como usuário de TDIC e autor de aulas virtuais na formação do licenciando potencializou a capacitação do futuro educador de enfermagem.

PALAVRAS-CHAVE: 1. Enfermagem 2. Educação em saúde 3. Educação à Distância 4. Tecnologia Educacional 
Afonso, VLM. Virtual lessons in Nursing licentiate degree course: Students as authors. [dissertation]. São Paulo: School of Nursing, University of São Paulo; 2014.

\begin{abstract}
Introduction: The instrumentalization of teachers in the use of digital technologies of information and communication (TDIC) points out the prospect of an innovative and reflective practice, optimizing the quality of teaching and learning in nursing. Objective: To describe virtual lessons built by nursing licentiate students for nurse technician. Method: This is an exploratory-descriptive research, documentary type, developed in the School of Nursing, University of São Paulo (EEUSP) in the licentiate degree course in class ENO 0336 - Education Workshops: Experiencing the process of education in nursing. The research had as objects 33 virtual lessons on the Moodle platform in 2012. Data gathering occurred through documentary analysis according to the model of Contextualized Instructional Design (CID). Results: 33 virtual lessons were produced by students and for each one the researcher built an instructional design matrix, enabling a comprehensive and informative overview of how the future nursing faculty organized the educational material at the virtual environment. The matrix were composed by categories: aims, roles, activities, course load, tools, content and evaluation of learning. Only one lesson did not stated objectives, most lessons proposed initial levels of knowledge and understanding, but none reached the six levels suggested by Bloom's taxonomy. All lessons showed the presence of the supporting role, related to teaching activities (nursing licentiate) and learning (students of nursing technical education). The future teachers planned diverse and creative activities, presented as cognitive triggers practical activities related to social, academic and health of audience context. The complex activities contemplated
\end{abstract}


reading articles, slides, the resolution of case study and online research. In most classes the set time of 4 hours was respected, considering the number and complexity of activities. A wide variety of tools such as chat, quiz, discussion forum, glossary, collaborative library, crossword and videos were used, allowing different degrees of interaction among individuals. The attempt to establish a bond with the student was a recurring concern, either through the creation of animated characters, such as virtual tutors, as to the language used. Licentiate selected current and relevant content to students and also produced online content. No technical difficulties were observed in the creation of virtual lessons and student teachers demonstrated significant ability to gather content, upload files and make information available, since they are considered as digital fluent. The presence of evaluation criteria, in most lessons, indicates the concern of licentiate to provide information about how it will measure student performance. Conclusions: The quality and diversity of educational material produced consisted in a significant pedagogical collection, especially for having been produced by teachers on training. Add the value of TDIC user experience and authorship of virtual lessons on the training of licentiate enhanced the practice of future nursing educator.

KEYWORDS: 1. Nursing 2. Health Education 3. Distance education.

4. Educational technology. 


\section{LISTA DE ILUSTRAÇÕES E TABELA}

Figura 1. Fases do processo de design instrucional do modelo Addie.

Figura 2. Elementos da matriz de design instrucional.

Figura 3. Página Inicial da disciplina no Moodle.

Figura 4. Destaque das orientações para elaboração da aula virtual.

Figura 5. Representação gráfica da ordem de apresentação dos dados segundo a matriz de design instrucional.

Figura 6. Estruturação da Taxonomia de Bloom no domínio cognitivo.

Figura 7. Exemplos de objetivos selecionados das matrizes.

Figura 8. Exemplo da ordem das atividades apresentadas em aula virtual.

Figura 9. Exemplo da ordem das atividades apresentadas em aula virtual.

Figura 10. Matriz da aula virtual 17, duração da carga horária prevista excedente.

Figura 11. Matriz da aula virtual 14 , duração da carga horária prevista incipiente.

Figura 12: Tela do vídeo de demonstração de procedimento em inglês, aula virtual 3 .

Figura 13: Glossário criado e preenchido para aula virtual.

Figura 14: Tela da aula virtual 1, proposição de pesquisa online.

Figura 15: Tela de vídeo selecionado no Youtube para a aula virtual 6 sobre a temática Hanseníase.

Figura 16: llustração do vídeo animado produzido na aula virtual 17.

Figura 17: Tela inicial da aula virtual número 13.

Figura 18: Tutora virtual criada para auxiliar na explicação da rota de aprendizagem.

Figura 19: Critérios de avaliação de aula virtual 17.

Tabela 1- Número de objetos de aprendizagem utilizados: total e média de uso nas 33 aulas virtuais. 


\title{
LISTA DE SIGLAS
}

\author{
AVA - Ambiente Virtual de Aprendizagem \\ CEP - Comitê de ética em pesquisa \\ CNPq - Conselho Nacional de Pesquisa \\ DI - Design Instrucional \\ DIC - Design Instrucional Contextualizado \\ EaD - Educação a Distância
}

EEUSP - Escola de Enfermagem da Universidade de São Paulo

ENO - Departamento de Orientação Profissional da EEUSP

EUA - Estados Unidos da América

GEPETE - Grupo de Estudos e Pesquisas de Tecnologia da Informação nos Processos de Trabalho em Enfermagem

LBD - Lei de Diretrizes e Bases da Educação Nacional

MOODLE - Modular Object-Oriented Dynamic Learning Environment

PAE - Programa de Aperfeiçoamento do Ensino

PDF - Portable document format

PPGEn - Programa de Pós-Graduação em Gerenciamento em Enfermagem

TCLE - Termo de Consentimento Livre e Esclarecido

TDIC - Tecnologias Digitais de Informação e Comunicação

USP - Universidade de São Paulo

OA - Objeto de aprendizagem 


\section{SUMÁRIO}

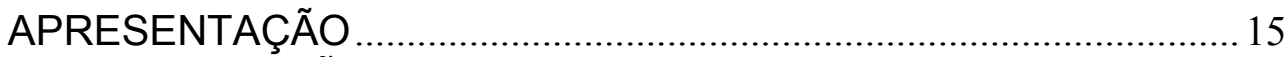

1. INTRODUÇÃO

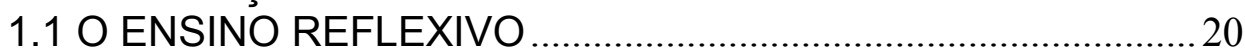

1.2 TECNOLOGIAS DIGITAIS NO ENSINO ……………...............25

1.3 O USO DE TECNOLOGIAS DIGITAIS NO ENSINO EM ENFERMAGEM ....................................................................... 30

1.4 O CURSO DE LICENCIATURA EM ENFERMAGEM ................34

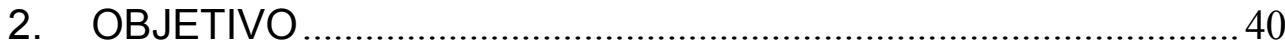

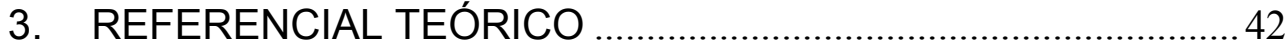

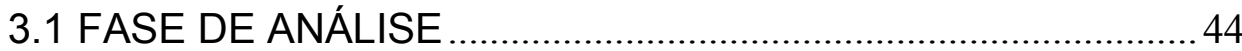

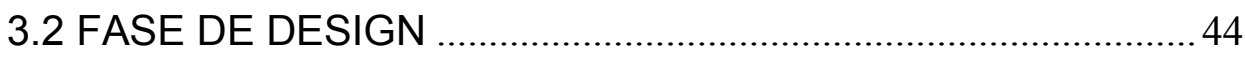

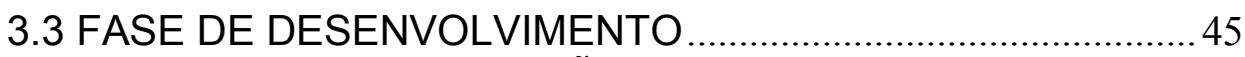

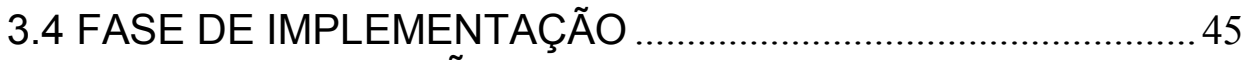

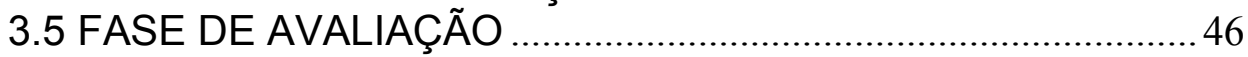

3.6 MATRIZ DE DESIGN INSTRUCIONAL ........................................4

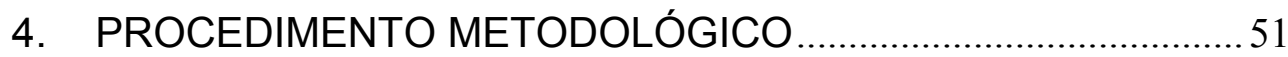

4.1 TIPO DE PESQUISA ……………………………….............. 51

4.2 CENÁRIO DO ESTUDO …………………………………........ 51

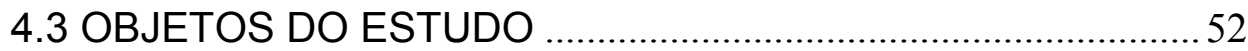

4.4 PROCEDIMENTO PARA COLETA DE DADOS ….......................53

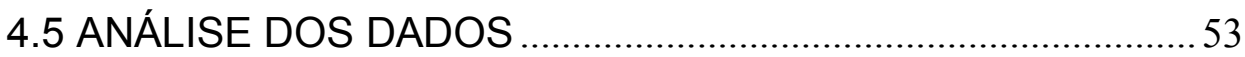

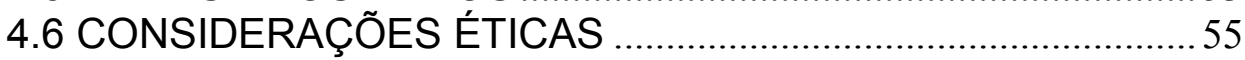

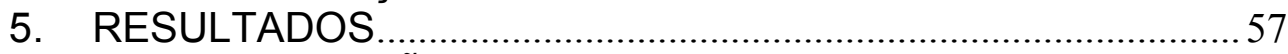

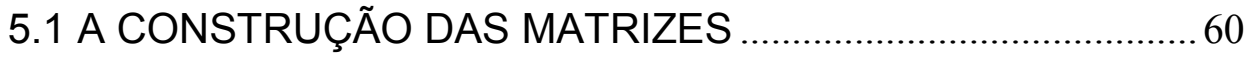

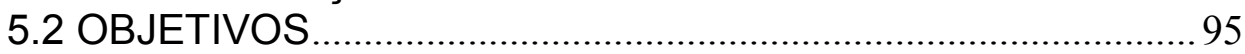

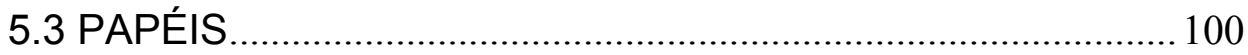

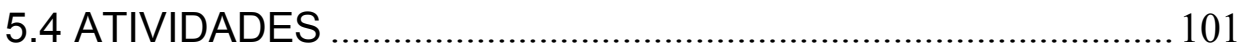

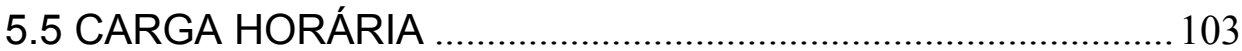

5.6 AMBIENTE: FERRAMENTAS E CONTEÚDOS ........................106

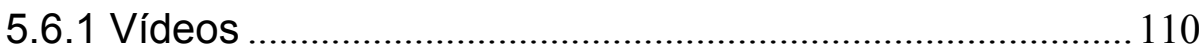

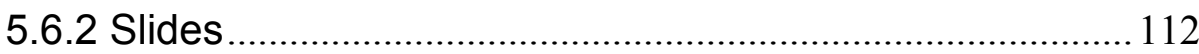

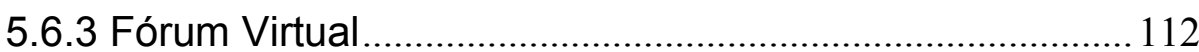

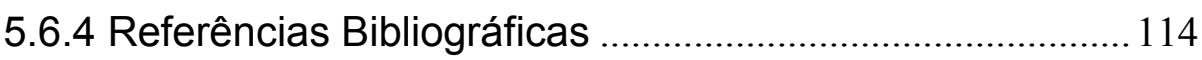

5.6.5 Glossário e Webquest: Potencial subaproveitado ............ 114

5.6.6. Plano de aula: Utilização incipiente......................................116

5.7 AVALIAÇÃO ………………………………………............ 120

5.8 POTENCIALIDADES E FRAGILIDADES DA FORMAÇÃO

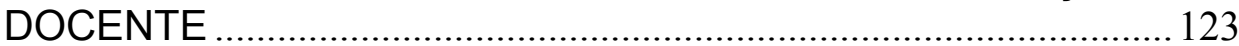

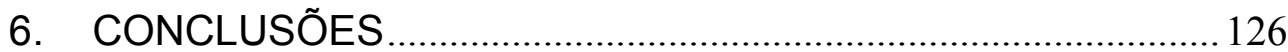

7. CONSIDERAÇÕES FINAIS.

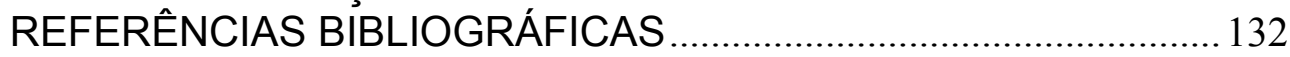

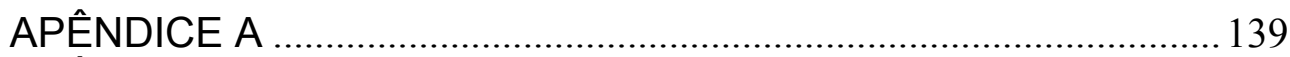

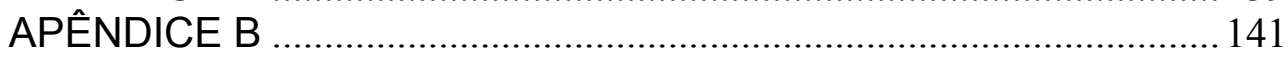

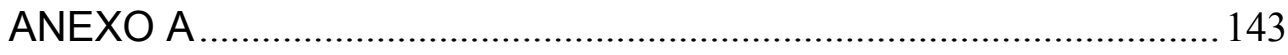




\section{APRESENTAÇÃO}

\section{O INÍCIO DA CAMINHADA...}

Como aluna do Curso de Graduação em Enfermagem da Escola de Enfermagem da Universidade de São Paulo - EEUSP, desde 2008 sempre busquei aperfeiçoar minhas reflexões acerca do ensino em enfermagem. Nesta direção, tive a oportunidade de participar como bolsista do Programa de Iniciação Científica do Conselho Nacional de Pesquisa - CNPq/ PIBIC/2009-2010 no projeto "Metodologia Dialética: Elaboração e validação de aula virtual na plataforma Moodle".

Esse estudo tinha por objetivo elaborar e avaliar uma aula virtual sobre a "Metodologia Dialética" em ambiente virtual de aprendizagem, projeto este vinculado por meio do programa de iniciação científica ao Departamento de Orientação Profissional ENO da EEUSP, ao Curso de Licenciatura em Enfermagem da EEUSP e ao Grupo de Estudos e Pesquisas de Tecnologia da Informação nos Processos de Trabalho em Enfermagem (GEPETEEEUSP).

O resultado do estudo foi o produção tecnológica de material educacional online em enfermagem, o qual foi avaliado por uma comissão de juízes da área de informática e/ou comunicação, e educação em enfermagem qualificando-a para ser disponibilizada em ambiente virtual no Curso de Licenciatura em Enfermagem da EEUSP. A produção deste material educacional, ao apresentar diversas mídias com conteúdos conceituais, reflexivos e lúdicos possibilitou uma heterogeneidade de atividades para a efetiva mobilização, construção e síntese do conhecimento pelo aluno.

Após a implementação da aula no curso foi necessário avaliar a aprendizagem dos licenciandos nesta temática. Foi então que dei continuidade, como bolsista, no Programa de Iniciação Científica do Conselho Nacional de Pesquisa - CNPq/ PIBIC/2010-2011 com o 
projeto "Avaliação da aprendizagem e análise da experiência de licenciandos de enfermagem em aula virtual".

Os resultados revelaram que os alunos demonstraram capacidade de compreender o tema e associá-lo à prática profissional bem como demonstraram alto grau de interação no fórum de discussão proposto na aula. Destacaram a importância da aula virtual como espaço de aprendizagem significativa e colaborativa, levando-os a construir seu próprio conhecimento mediado por intervenções do professor.

Deste modo, guiada pelo ideal de transformações significativas na educação em enfermagem construí meu trabalho de conclusão de curso - TCC, do Curso de Graduação em Enfermagem, intitulado "Aula virtual na licenciatura em enfermagem: da elaboração à avaliação da aprendizagem".

A construção das primeiras aulas virtuais do Curso de Licenciatura da EEUSP foi uma tarefa intensa da qual tive o privilégio de participar, pois mesmo sendo um trabalho pioneiro e sujeito a inúmeros ajustes, sempre obtivemos avaliações positivas e incentivadoras dos alunos e pesquisadores da área.

Ingressei no curso de pós-graduação da EEUSP no Programa de Mestrado do PPGEn e dentro deste no programa de aperfeiçoamento de ensino (PAE). O programa destina-se exclusivamente aos alunos matriculados nos cursos de mestrado $\mathrm{e}$ doutorado e objetiva aprimorar a formação docente através de atividades didático-pedagógicas supervisionadas.

Minha escolha por ser aluna do Programa PAE dentro da licenciatura foi devido à aproximação que já possuía com as disciplinas do curso. Incluí-me, então, como docente e aluna na arte de ensinar, ponto relevante, pois, na primeira experiência como professora de um curso que corrobora com meus ideais, me permito 
apreciar, conhecer e refletir sobre os complexos mecanismos do processo de ensino-aprendizagem.

Por outro lado, pude perceber a importância da formação continuada do professor ao auxiliar o aluno no delineamento correto da sua experiência de aprendizagem.

O carinho pela área de educação em enfermagem sempre permeou meus pensamentos, por acreditar que é pelo ensino que podemos modificar a realidade da profissão.

Faziam parte como atribuições de aluna do Programa PAE, o auxílio aos tutores na plataforma virtual e no desenvolvimento das aulas virtuais. A tríade estabelecida entre o licenciando, o tutor e o ambiente virtual torna-se produtiva à medida que as interações permitem um processo de construção da comunidade, ou seja, promover que os alunos criem em conjunto o conhecimento. Para tanto, compreendi necessidades e identifiquei potencialidades dos alunos que surpreendiam com o excelente desempenho a cada atividade.

Indagações de como se dá o acesso às informações e como ocorre o acesso ao conhecimento fizeram parte das minhas reflexões acerca do ensino online. $O$ acesso à informação permeia qualquer área de conhecimento $\mathrm{e}$, portanto, é inerente à enfermagem.

Uma das motivações para a escolha do tema deste estudo foi por acreditar que a educação mediada pela tecnologia, em especial o uso dos ambientes virtuais, conduz o aluno a experiências educativas positivas e gera uma mobilização para o conhecimento. Estes recursos fazem parte do momento histórico que nossos alunos vivenciam e, por esta razão, podem tornar a aprendizagem mais significativa e prazerosa. 
Nesse contexto surgem ideias no sentido de investigar que conceitos pedagógicos os alunos da licenciatura trazem ao pedirmos para que o licenciando construísse sua própria aula virtual. Assim, trabalhamos com conhecimentos prévios e trouxemos a experiência do que aprenderam enquanto alunos de aulas virtuais anteriores.

Uma nova experiência ao propormos que futuros docentes reflitam sobre a inserção de tecnologias digitais na educação em enfermagem e especificamente sobre a possibilidade de serem autores de aulas virtuais, por meio do processo de planejamento de uma aula online, atividade essa na qual poderá se deparar no futuro profissional.

Portanto, torna-se importante esse projeto à medida que une interesses no uso de tecnologias no ensino em enfermagem acrescido a formação profissional do enfermeiro docente na era digital.

Dessa forma minhas inquietações dão suporte e força à minha motivação para desenvolver essa pesquisa buscando colher os frutos de algumas sementes plantadas nos últimos 5 anos junto aos alunos do Curso de Licenciatura em Enfermagem da EEUSP. 
1 INTRODUÇÃO 


\section{INTRODUÇÃO}

\subsection{O ENSINO REFLEXIVO}

A educação tem vivenciado um momento histórico de transição, devido a mudanças sociais e novas descobertas tecnológicas que acontecem a todo instante nas diferentes áreas de conhecimento.

Essas transformações refletem diretamente nos processos de trabalho, exigindo o desenvolvimento de habilidades metacognitivas e de competências para aprender cooperativamente, apoiadas em conteúdos contextualizados e na experiência individual.

Ao relacionar metacognição com estratégias de ensino aprendizagem, o conceito mais adequado para definir o primeiro termo concebe a mente como um sistema cognitivo pelo qual se interage com 0 meio, nesse processo ocorre monitoração, autorregulação e potencialização do próprio sistema. A metacognição não é apenas um conhecimento sobre a cognição, mas uma etapa do processamento de nível elevado, que é adquirida e desenvolvida pela experiência e pelo conhecimento específico que é armazenado (JOU; SPERB, 2006).

As modificações na forma de trabalhar, evidentes através da automatização dos processos de trabalho e ampla circulação de informações, assim como a forma de aprender, emergem uma necessidade emancipatória, que busque proporcionar autonomia e contribua efetivamente para a formação do indivíduo.

Os atuais métodos de ensino valorizam a troca de informações entre aluno e professor ao invés da transmissão unidirecional de informação. No lugar da reprodução passiva de informações, exalta-se o estímulo à criatividade dos estudantes. Não ao currículo padronizado desconexo da realidade do aluno e de seus 
interesses, falta de acesso à educação de qualidade, à educação bancária. Sim à pedagogia de projetos centralizados na aprendizagem significativa, na educação por toda a vida e no aluno como protagonista. (SILVA, 2003)

O enfoque de ensino problematizador tem sido considerado uma ferramenta estratégica para compreensão da realidade, para intervir e transformá-la. Nessa perspectiva, evidencia-se o aluno como sujeito da aprendizagem e o professor como facilitador e mediador do processo ensino-aprendizagem.

A habilidade de problematizar é vista como a capacidade de relacionar de forma coerente e sequencial três momentos: identificação de um problema, busca de explicação e proposição de soluções. (ZANOTTO; ROSE, 2003).

Para Paulo Freire, grande educador, a educação problematizadora, de caráter autenticamente reflexivo, implica num constante ato de desvelamento da realidade. (...) busca emersão das consciências, de que resulte sua inserção critica na realidade. (FREIRE, 1970, p. 40).

A educação deve apreciar os interesses dos alunos, ou seja, o ensino através de métodos eficazes e dinâmicos, valorizando e promovendo a aprendizagem do mesmo através da experiência vivenciada no cotidiano e na curiosidade natural em busca da construção de novos saberes. Assim, nessas circunstâncias, emergem as dimensões problematizadoras, as quais assumem a construção do conhecimento como traço definidor da apropriação de informações e explicação da realidade, tomando-a como ponto de partida e chegada do processo de aprendizagem.

Identificam-se duas propostas na dimensão problematizadora do processo ensinoaprendizagem: a Pedagogia da Problematização e a Aprendizagem Baseada em Problemas (ABP). A problematização encontra nas formulações de 
Paulo Freire um sentido de inserção crítica na realidade para dela retirar os elementos que conferirão significado e direção às aprendizagens. No movimento ação-reflexão-ação são elaborados os conhecimentos, considerando a rede de determinantes contextuais, as implicações pessoais e as interações entre os diferentes sujeitos que aprendem e ensinam. (BATISTA et al, 2005, p. 232).

Baseado no percurso educacional que é escolhido, as propostas educacionais interferem diretamente na motivação do sujeito ao se mobilizar para o aprendizado e na disponibilidade que ele demonstrará a experiências futuras. Experiências positivas e interativas tem uma maior capacidade de instituir condições e estimular competências para experiências futuras.

Para John Dewey (1938) a crença de que a educação genuína surge através da experiência não significa que todas as experiências são genuinamente ou igualmente educativas. Experiência e educação não podem ser diretamente comparadas entre si, pois algumas experiências não são educativas. Qualquer experiência não educativa tem o efeito de prender ou distorcer o crescimento de uma experiência maior.

Nesse sentido, as ações do docente devem se pautar no desenvolvimento da capacidade de raciocínio e espírito crítico do aluno. Essa compreensão remete a uma prática docente baseada na liberdade do aluno para elaborar as próprias certezas, os próprios conhecimentos, as próprias regras morais. Isso não significa reduzir a importância do currículo ou dos saberes do educador.

Refletindo a respeito da prática docente, o educador não tem que estar somente atento ao princípio geral de que as condições do meio modelam o aprendizado do aluno, mas também reconhecer que nas situações concretas, as circunstâncias conduzem a experiências que produzem o conhecimento. 
Notamos então a prática reflexiva como postura fundamental para quem tem a missão de ensinar.

Nas sociedades em transformação, a capacidade de inovar, negociar e regular a prática é decisiva. Ela passa por uma reflexão sobre a experiência, favorecendo a construção de novos saberes. (PERRENOUD et al, 2002).

\begin{abstract}
A prática reflexiva precisa estar vinculada à participação critica, ou seja, exige que este professor considere-se parte do problema e reflita sobre a sua própria relação com o saber, com as pessoas, com o poder, com as instituições, as tecnologias, o tempo que passa, a cooperação, tanto quanto sobre o modo de superar as suas próprias limitações. (PERRENOUD, 1999, p. 5).
\end{abstract}

A reflexão é essencial para as mudanças educacionais necessárias à evolução do ensino. Cria oportunidades para que os educadores adotem uma postura crítica de suas práticas e da estrutura na qual estão inseridos. Para tanto, o educador deve ser um profissional reflexivo, comprometido com o processo educativo, integrado as demandas sociais e, principalmente, um eterno aprendiz, aquele que busca inovar e inovar-se. (VALENTE, 2009).

A evidente necessidade de atualização profissional é uma premissa constante na realidade do profissional egresso dos cursos superiores, portanto, deve-se estimular constantemente o profissional para que ele seja ativo e busque aprimorar o desempenho de suas competências profissionais.

O aprendizado adquirido pela formação acadêmica há algumas décadas atrás, era suficiente para cada indivíduo desempenhar sua atividade profissional até a aposentadoria, contudo hoje é imprescindível a procura constante por novos saberes como cursos de atualização, especialização, mestrado e doutorado para manutenção de suas atividades no mercado de trabalho ditado pela nova dinâmica mundial do fluxo contínuo de informações (RODRIGUES, 2008). 
Ao analisarmos o ensino universitário especificamente, identificamos alguns pressupostos que devem ancorar a aprendizagem para que esta se torne significativa na construção de saberes de seus sujeitos: o conhecimento prévio para a mediação de novas aprendizagens; a diversificação de cenários que facilitem a construção de novos conhecimentos; o entendimento de que conhecer implica acesso e constante reconstrução das informações; a valorização da prática como estrutura para o aprender; a compreensão de que a motivação para aprendizagem produz-se no cruzamento dos projetos pessoais com as condições socioeducativas.

A formação para a docência é um tema amplamente discutido devido a sua importância para o desenvolvimento da sociedade, portanto, sofre grande influência na sua forma de organização e de reprodução social.

Sobre a perspectiva da prática pedagógica, Perrenoud (1993) afirma que quando os alunos chegam ao curso de formação universitária, já aprenderam saberes sobre o que é ser professor, pois os saberes de sua experiência de alunos que foram de diferentes professores em toda a vida escolar contribuíram para sua formação humana.

Entretanto, a atividade profissional na docência ainda é vista como precária no Brasil, especialmente no âmbito da educação profissional (PENA, 2011). Segue dessa maneira devido às deficiências do sistema de ensino em contemplar aspectos práticos das áreas de conhecimento, bem como aspectos pedagógicos do ensinar e construir-se docente.

Faz-se necessário, também, o intercâmbio entre formação inicial e formação continuada, de maneira que a formação dos futuros professores se nutra das demandas da prática e que os 
professores em exercício frequentem a universidade para discussão e análise de problemas concretos da prática. (LIBÂNEO, 2002)

De acordo com Piconez e Filatro (2009), a qualidade do sistema educativo de um país depende de seus docentes. As práticas docentes têm efeito relevante sobre $\mathrm{o}$ ensino $\mathrm{e}$ a aprendizagem. Diante dos desafios e mudanças decorrentes da presença das tecnologias de informação e de comunicação faz-se necessário que o docente tenha uma formação pedagógica sólida, seja capaz de utilizar diferentes métodos de ensino concomitante com a capacidade de inovar. Para isso, torna-se necessário um ambiente de apoio estrutural e pedagógico.

O aprendizado eletrônico tem trazido mudanças paradigmáticas da teoria e prática educacional. Mediante essa realidade, as Tecnologias de Informação e Comunicação (TIC) sem dúvida agregam valor à formação do sujeito crítico e a prática docente reflexiva, tornando promissora a trajetória a uma educação de qualidade.

\subsection{TECNOLOGIAS DIGITAIS NO ENSINO}

Demandas sociais e expectativas no acesso à informação e ao conhecimento são atualmente o grande desafio aos estilos formais de ensino, pois a preocupação está em como gerir essa grande quantidade de informação. Estes elementos afinam-se com os propósitos da educação a distância e impulsionam o seu crescimento.

A integração da aprendizagem a elementos tecnológicos é sensível à uma sociedade transformadora, pertinente ao aumento da procura dos métodos flexíveis de aprendizagem e de tecnologias de informação. 
O indiscutível avanço das tecnologias digitais provocou mudanças consideráveis no processo de comunicação-informação. A internet tornou a comunicação mais dialógica e interativa, discorremos então sobre a educação online e não somente educação à distância, esta última que conglomera o modelo analógico de transmissão um-todos, ou um-um, através da televisão, rádio, correio, etc. (KRATOCHWILL, 2008).

A educação online é "uma ação sistemática de uso de tecnologias, abrangendo hipertexto e redes de comunicação interativa, para distribuição de conteúdo educacional e promoção da aprendizagem sem limitação de tempo ou lugar" (FILATRO, 2004, p. 47).

A educação online, compreendida dentro da educação à distância $(\mathrm{EaD})$, se descortina como um passo além. Emergem grandes incentivos ao uso da interatividade da internet na aprendizagem e tornam-se obsoletos modelos de transmissão de conhecimento unidirecionais.

A educação online proporciona um universo de possibilidades, flexibilidade e contempla necessidades da nova tendência mundial.

A EAD online é exigência da cibercultura, isto é, do conjunto imbricado de técnicas, práticas, atitudes, modos de pensamento e valores que se desenvolvem juntamente com o crescimento do ciberespaço, isto é: do novo ambiente comunicacional que surge com a interconexão mundial de computadores e das memórias dos computadores; principal suporte de trocas e de memória da humanidade a partir do século XXI; novo espaço de comunicação, de sociabilidade, de organização, de informação, de conhecimento e, claro, de educação. (SILVA, 2003, pág. 11). 
A mobilidade de aprendizagem, resultado do novo ambiente comunicacional, deve permitir que o aluno desenvolva novas competências.

\begin{abstract}
A introdução de novos objetivos de aprendizagem e de novas metodologias de ensino não lhes permitirá mais organizar seu ensino em torno de uma sucessão rígida de lições e fichas de trabalho, e sim os obrigará a inventar permanentemente arranjos didáticos e situações de aprendizagem que respondam melhor à heterogeneidade de necessidades de seus alunos. (PERRENOUD et al. 2002).
\end{abstract}

Frente a essas novas demandas, a utilização das tecnologias como instrumento no processo ensino e aprendizado vem ao encontro desses novos paradigmas e surge de maneira expressiva nas instituições de ensino superior.

O artigo 80 das disposições gerais da Lei de Diretrizes e Bases da Educação (LBD), n9394/96 refere-se à educação à distância estabelecendo que o poder público incentivará o desenvolvimento e a veiculação de programas de ensino à distância, em todos os níveis e modalidades de ensino, e de educação continuada. Isso reflete uma tendência mundial, onde o crescimento da oferta e procura por educação à distância deve-se a esse grande potencial para enriquecer e modernizar o processo tradicional (presencial) de ensino-aprendizagem, para universalizar e democratizar o acesso à educação. (NEVES, 1998)

Ao ver a educação como um instrumento de crescimento humano, enaltecemos o potencial da tecnologia como condutora na mudança da condição dos indivíduos.

Vale então destacar que a inclusão das tecnologias poderá possibilitar a individualização do ensino e repensar a natureza da aprendizagem, por dissolver a distinção entre educação formal e informal, devido a democratização da informação, abrindo novas 
oportunidades para todos que querem e podem ensinar e aprender. Assim, os recursos da informática são realidade nas novas perspectivas na educação.

É fundamental refletir em como as tecnologias são disponibilizadas, como seu uso pode, efetivamente, desafiar as estruturas existentes em vez de reforçá-las. (SILVA, 2003)

A escola necessita estar preparada para interagir com um aluno autônomo e criativo bem como adotar práticas pedagógicas que acompanhem e incentivem esses sujeitos. Neste sentido, as tecnologias digitais quando aplicadas a materiais educacionais aparecem como uma ferramenta capaz de potencializar a reestruturação de práticas pedagógicas, originando novos pensares a respeito do uso da comunicação, da ciência da informação da construção do conhecimento e sua interação com a realidade. (TORREZZAN, 2009)

Com a intenção de suprir algumas limitações como o pouco dinamismo das interações em classe e o incentivo a construção do conhecimento individual e coletivo entre esses sujeitos, muitos cursos de graduação tem adotado o ambiente virtual de aprendizagem (AVA).

Almeida (2003, p.331) afirma que os ambientes virtuais de aprendizagem,

[...] são sistemas computacionais disponíveis na internet, destinados ao suporte de atividades mediadas pelas tecnologias de informação e comunicação. Permitem integrar múltiplas mídias, linguagens e recursos, apresentar informações de maneira organizada, desenvolver interações entre pessoas e objetos de conhecimento, elaborar e socializar produções tendo em vista atingir determinados objetivos. As atividades se desenvolvem no tempo, ritmo de trabalho e espaço em que cada participante se localiza, de acordo com uma intencionalidade explícita e um planejamento prévio denominado design 
educacional, o qual constitui a espinha dorsal das atividades a realizar, sendo revisto e reelaborado continuamente no andamento da atividade.

O ambiente virtual de aprendizagem é dito como recurso que aperfeiçoa a dinâmica da sala de aula, proporciona aos alunos melhor aproveitamento dos conteúdos teóricos que se tornam mais atrativos, personalizando sua aprendizagem à medida que podem acessar o ambiente em local e tempo a critério de suas disponibilidades. (TANAKA, 2010)

O AVA tem por base princípios educacionais que privilegiam a reconstrução do conhecimento, a autoria, a produção de conhecimento de forma colaborativa e a aprendizagem significativa do aluno, permitindo assim ampliar o espaço físico da sala de aula como espaço de aprendizagem, permitindo ainda diferentes formas de interação, constituindo-se assim, as redes de aprendizagem.

Prado et al (2011) ressaltam que o planejamento, feito pelo professor, de um curso em AVA deve transpor o modelo utilizado no ambiente presencial e proporcionar atividades educacionais específicas, que incentivem a colaboração, interação, reflexão e construção coletiva do conhecimento, que são estruturalmente diferentes de situações em ambientes presenciais.

O desenvolvimento de objetos educacionais digitais é um recurso de apoio ao ensino presencial que respeita a autonomia do aluno, restrições de tempo, pois permite o estudo extraclasse por meio do ambiente virtual de aprendizagem. (COGO, SILVEIRA, CATALAN, 2006)

A usabilidade de objetos educacionais em ambiente virtual de aprendizagem é um recurso possível de ser utilizado na formação de enfermeiros. Aos professores, comprometidos com a qualidade do ensino, cabe reconhecerem o papel das tecnologias da 
comunicação e da informação. Isso significa considerar que o computador, embora sendo um instrumento versátil e poderoso, sua presença, por si só, não garante um processo educacional efetivo. (TANAKA, 2010)

Para tanto, é preciso que sejam feitos investimentos na concientização do discente e na preparação para uma experiência efetivamente positiva e transformadora.

Todas as universidades e organizações
educacionais, em todos os níveis, precisam
experimentar como integrar o presencial e o virtual,
garantindo a aprendizagem significativa.
Precisamos vivenciar uma nova pedagogia do
presencial e do virtual. [...] É importante que os
núcleos de educação à distância das universidades
saiam do seu isolamento e se aproximem dos
departamentos e grupos de professores
interessados em flexibilizar suas aulas, que
facilitem o trânsito entre o presencial e o virtual.
(MORAN, 2003, pg. 45).

\subsection{O USO DE TECNOLOGIAS DIGITAIS NO ENSINO EM}

\section{ENFERMAGEM}

Os cursos de ensino a distância nas áreas biológicas, concentram-se em sua grande maioria no nível de formação pósgraduação e extensão. Na graduação, ainda demonstram uma imaturidade do sistema educacional em lidar com o ensino online ao refletir conceitos errôneos acerca do EaD utilizado, muitas vezes, como recurso na falta de tempo do profissional para sua formação e para complementação da carga horária do curso.

Apesar da importância dessa apropriação da competência tecnológica por parte dos enfermeiros, a inserção da enfermagem no panorama do ensino on-line brasileiro ainda é incipiente, havendo ainda a necessidade das instituições de ensino superior adotarem políticas de investimento na capacitação tecnológica docente e 
discente, bem como na implementação de infraestrutura para o desenvolvimento de projetos de educação à distância estruturada em propostas pedagógicas que viabilizem a construção de competências, habilidades e conhecimento nas áreas de tecnologia da informação e de educação utilizando novas estratégias de ensino. (RODRIGUES, PERES, 2008)

A enfermagem é considerada por muitos uma profissão essencialmente prática, porém, este fato não se opõe à utilização da EaD como forma ou meio para viabilizar a educação continuada através da realização de cursos livres, de extensão e pós-graduação online. (RODRIGUES, PERES, 2008)

O apoio da instituição na utilização do ensino online é fundamental, bem como a política sobre a qual essa estratégia será vinculada na formação do aluno, para que se configure realmente uma estratégia de ensino e não perca seu real sentido e seu potencial.

O apoio institucional se faz presente através de um projeto bem delineado, verbas específicas e professores engajados e comprometidos em incorporar o uso de tecnologias no seu cotidiano, em sua prática profissional docente.

O uso de tecnologias nas mais variadas áreas do ensino em enfermagem demonstra potencial devido à ampliação de recursos voltados ao ensino para a prática assistencial, caracterização dos discentes e também dos ambientes virtuais utilizados.

A literatura levanta reflexões a respeito das tecnologias na área do ensino em enfermagem como ambiente fértil para a promoção e inserção de propostas educacionais utilizando ambiente virtual de aprendizagem, visando fomentar o ensino online. A evolução seria possibilitar a realização de atividades individuais e também o ensino colaborativo, interativo e flexível. 
É nessa perspectiva desafiadora que se descortina a área de educação em Enfermagem, visto o avanço das tecnologias da informação e comunicação nos espaços acadêmicos. Esse enfoque instiga os educadores a conhecerem, analisarem e transformarem essas novas tecnologias em um instrumento educacional articulado às condições políticas, econômicas, sociais e culturais nas quais o ensino se insere, bem como atenderem as demandas da uma clientela universitária considerada de uma geração digital. (COSTA et al, 2011)

A pesquisa de Costa et al (2011), traz a identificação da fluência digital dos alunos do curso de Licenciatura em Enfermagem da Escola de Enfermagem da USP - EEUSP, bem como identificação do conhecimento, habilidade e interesse no uso do AVA. A amostra contou com 51 licenciandos de enfermagem.

Seus resultados comprovam que $100 \%$ dos pesquisados afirmaram algum conhecimento em informática, sendo 26,51\% em nível intermediário, $100 \%$ dos licenciandos utilizam a internet e possuem e-mail, a grande maioria (92\%) informa utilizar diariamente tendo como principais locais de acesso a própria residência (85\%) e a universidade $(21 \%)$.

Nesse estudo, os resultados apontaram que os licenciandos de Enfermagem são fluentes digitais, visto que são capazes de encontrar, avaliar e utilizar informação digital de forma eficaz, eficiente e ética.

A importância desse estudo sobre a fluência digital se configura na necessidade de conhecer o perfil dos alunos com os quais se trabalha e de conhecer suas experiências e interesses. Espera-se que o professor conduza o processo de ensinoaprendizagem adequando o ambiente virtual às necessidades dos discentes. 
Para que exista uma evolução do ensino online, o aluno virtual precisa acreditar que a aprendizagem de alta qualidade possa ocorrer em qualquer lugar e a qualquer momento e não apenas na sala de aula presencial. Os alunos virtuais são, ou passam a ser, pessoas que pensam criticamente. Eles sabem que o professor atua como facilitador do processo de aprendizagem e que para chegarem à melhor experiência online, devem ser eles próprios responsáveis pelo processo. (PALLOFF e PRATT, 2004)

O aluno virtual de sucesso possui a mente aberta e compartilha sua experiências educacionais e detalhes da vida, além do trabalho e suas concepções de mundo. Para que se tenha sucesso no ambiente virtual o aluno precisa ser flexível e aberto a novas experiências e idéias. Pode tornar-se alguém que aprende durante a vida inteira, incentivado a buscar o conhecimento sempre. (PALLOFF e PRATT, 2004)

Quanto aos aspectos de habilidade no uso de AVA e no interesse, 64,7\% utilizam frequentemente o Moodle (Modular ObjectOriented Dynamic Learning Environment) e 88,2\% gostariam de utilizá-lo durante sua formação. Citaram o armazenamento de conteúdo das aulas, a otimização do tempo, flexibilidade de acesso, e outros meios e ferramentas no processo ensino aprendizagem, saindo da monotonia do modelo tradicional.

A elevada porcentagem de utilização do Moodle reflete a divulgação e o acesso à plataforma pela Universidade de São Paulo, cada vez mais presente no cotidiano dos docentes.

A plataforma Moodle é um software livre, ou seja, propicia a liberdade de execução, cópia, distribuição, estudo, alteração e aperfeiçoamento. (SEGUNDO, 2005)

A filosofia de software livre, convidando a comunidade a interagir e modificar constantemente contribuiu para o crescimento 
deste ambiente que apresenta uma interface amigável, permitindo aos usuários customizá-lo de acordo com os seus interesses e propósitos pedagógicos (ALVES, 2009).

Atualmente o Moodle é bastante conhecido entre estudantes e docentes. Teve um crescimento exponencial contando hoje com cerca de 62 milhões de usuários e presente em mais de 200 países. (Site MOODLE, 2012)

O criador do Moodle, Martin Dougiamas, tem formação em educação. Isto o conduziu a adotar o construcionismo social como a estrutura pedagógica em que está baseado o ambiente. Isto é inovador uma vez que os ambientes de gerenciamento de cursos são, em geral, construídos em torno de ferramentas computacionais. Pode-se afirmar que os sistemas de gerenciamento comerciais são voltados para ferramentas enquanto o Moodle é voltado para aprendizagem. (PULINO, 2007)

\subsection{O CURSO DE LICENCIATURA EM ENFERMAGEM}

Na docência voltada a educação profissional técnica de nível médio em enfermagem, a deficiência de profissionais com formação pedagógica é grande. Essa lacuna diminui a oferta de profissionais qualificados para que as instituições estruturem seu corpo docente. O que percebemos então são profissionais com grande saber em sua área específica da saúde e defasagem no campo da educação.

O compromisso docente vai além da simples reprodução das informações existentes, por mais atuais e técnicas que sejam; ele tem a ver com o fazer aprender, o deixar aprender, o garantir o processo de pensamento crítico, criativo, construtor de novas soluções para os novos problemas de realidade vivida ou de realidades nem sequer imaginadas: nesse contexto se situa a razão de ser da licenciatura. (ANASTASIOU, 2011, pág.3). 
Em pesquisa sobre a temática de enfermeiros docentes na educação profissional técnica de nível médio em enfermagem, Maissiat e Carreno (2010) buscaram sintetizar e caracterizar os artigos científicos encontrados. Pode-se observar a identificação de cinco temáticas:

- Prática pedagógica e/ou processo de ensino-aprendizagem; perfil; qualificação profissional (formação/capacitação/competência), condições de trabalho e os aspectos positivos. A temática qualificação profissional perfez o total de $88 \%$ da amostra da pesquisa, seguida pela temática prática pedagógica e/ou processo ensino aprendizagem, com $66 \%$. Nesse estudo encontrou-se apenas uma única pesquisa científica que aborda os aspectos positivos e motivadores dos enfermeiros enquanto docentes dos cursos técnicos em enfermagem.

A educação profissional técnica de nível médio em enfermagem é abordada por muitos trabalhos científicos, entretanto são escassos os estudos que tratam essencialmente do enfermeiro em atividade docente do ensino profissionalizante. A importância do desenvolvimento desse tema contribui na capacitação e educação continuada dos profissionais que atuam nessa área em enfermagem, além de mostrar as mudanças da educação, avaliação de seu trabalho frente ao que se encontra em evidência enquanto didática $e$ pedagogia. (MAISSIAT; CARRENO, 2010)

A formação do enfermeiro voltada para a docência implica na ampliação de competências para atuar na educação profissional técnica de nível médio. Os cursos de Licenciatura em Enfermagem, ou equivalente, levarão o enfermeiro ao desenvolvimento do conhecimento em didática e pedagogia. Nas competências do docente esses conhecimentos são fundamentais para que se formem profissionais de nível médio capacitados a atender as 
necessidades diárias decorrentes de suas funções (VALENTE; VIANA, 2006)

A graduação em enfermagem requer a apropriação de conhecimentos vastos na área da saúde, para o ensino em enfermagem não é diferente. É necessária a construção contínua de saberes pedagógicos para o exercício competente através da busca, elaboração e avaliação de ações educativas relacionadas à prática de saúde.

O Conselho Estadual de Educação de São Paulo, pela Indicação CEE n.64/2007, explicitou as exigências em relação aos docentes da educação profissional técnica de nível médio. Em decorrência, ficou definido que somente estão habilitados a lecionar os licenciados nos termos do Artigo 62 da LDB. São considerados licenciados os graduados em Enfermagem, com Licenciatura Plena. (COREN, 2008).

O Curso de Licenciatura em Enfermagem da Escola de Enfermagem da USP foi criado em 12 de março de 1974, como um curso vinculado à Faculdade de Educação e passou a ser de responsabilidade da Escola de Enfermagem no ano de 2005. Seu objetivo é formar professores para atuar no ensino médio, na educação profissional técnica de nível médio em Enfermagem e na formação continuada, como sujeitos de transformação, comprometidos com a busca de respostas a desafios e problemas existentes no âmbito do ensino profissional em Enfermagem (EEUSP, 2013).

Segundo a nova proposta do Projeto Político-Pedagógico (EEUSP, 2013), a incorporação das tecnologias educacionais é concebida como uma ferramenta facilitadora na construção da aprendizagem dos licenciandos, que Ihes possibilita atuar no ensino mediante uma ação pedagógica participativa, compartilhando 
conhecimentos, em prol da melhoria do ensino e, consequentemente, do atendimento à saúde da população.

Nessa perspectiva, o Curso de Licenciatura em Enfermagem da EEUSP vem utilizando, desde 2008, a tecnologia digital na formação de professores críticos, éticos e comprometidos com uma proposta diferenciada de recursos humanos em enfermagem para atender as demandas do mundo do trabalho.

Dessa maneira, ao utilizarmos a educação presencial e a distância em uma mesma disciplina, optamos por um processo educacional híbrido ou semi-presencial, vindo ao encontro das propostas de inovações pedagógicas preconizadas pela literatura.

Para tal, é preciso instrumentalizar o discente para o uso das tecnologias ampliando suas possibilidades de formação pedagógica para atuar nos cursos de formação de auxiliares e técnicos de enfermagem bem como para desenvolver educação permanente com vistas à promoção e a prevenção dos agravos à saúde da população.

A produção de objetos virtuais de aprendizagem ainda é incipiente na enfermagem, provável reflexo da estrutura rígida e prática com que o ensino nessa área se configurou durante muito tempo.

Atualmente, em disciplinas da licenciatura da Escola de Enfermagem da Universidade de São Paulo são utilizadas aulas virtuais sobre diferentes temas pertinentes à formação do professor, como por exemplo: Metodologia Dialética, Portfólio, Teoria da Aprendizagem Significativa, Professor Reflexivo e Andragogia.

As aulas virtuais aplicadas na licenciatura da EEUSP apresentam grande participação dos alunos e contribuições significativas. Os comentários sobre a experiência da aula em 
ambiente virtual é de que os conteúdos e as estratégias utilizadas foram pertinentes, produtivas e criativas, constituindo excelente material para o aperfeiçoamento deste método de ensino.

Cabe salientar que, que projetos pedagógicos inovadores têm como meta criar e utilizar estratégias pedagógicas que envolvam e mantenham a mobilização não só de docentes, corpo técnico e administrativo da escola, mas também dos alunos, na perspectiva da melhoria da qualidade do curso.

Portanto, acreditamos que essa proposta privilegia a formação do docente em enfermagem de forma crítica e reflexiva, tendo como um dos componentes de seu perfil a perspectiva de buscar e utilizar novos conhecimentos para o desenvolvimento da prática profissional, especialmente no uso de tecnologias.

Dessa discussão emerge o seguinte questionamento:

O licenciando em enfermagem é capaz de, através da utilização de conhecimentos prévios construídos no curso, produzir uma aula virtual criativa, adequada ao AVA e à educação profissional técnica de nível médio em enfermagem? 
2 OBJETIVO 


\section{OBJETIVO}

Descrever e analisar, conforme a matriz de design instrucional, aulas virtuais construídas por licenciandos de enfermagem. 


\section{REFERENCIAL TEÓRICO}

O modelo de Design Instrucional (DI) pode ser definido como a ação intencional e sistemática de ensino que envolve o planejamento, desenvolvimento e a aplicação de métodos, técnicas, atividades, materiais, eventos e produtos educacionais em situações didáticas específicas, a fim de promover, a partir de metodologias de ensino, a aprendizagem humana. Em outras palavras, como o conjunto de atividades que visa identificar um problema (uma necessidade) de aprendizagem e desenhar, implementar e avaliar soluções pertinentes para esse problema. (FILATRO, 2008)

O Design Instrucional é uma teoria, além de um processo, e um corpo de conhecimentos voltado a pesquisa e teorização das estratégias instrucionais. Este se dedica a construir conhecimento sobre os princípios e os métodos de instrução mais adequados a diferentes tipos de aprendizagem visando garantir a qualidade desta aprendizagem (FILATRO, 2008). Portanto, o Design Instrucional fundamenta o referencial teórico desta pesquisa tornando possível a análise sistemática das aulas virtuais construídas pelos licenciandos de forma coesa e clara.

A utilização do DIC na elaboração de um ambiente virtual de aprendizagem permite aos usuários a utilização de recursos diversos e flexibilidade na maneira de apresentar e acessar informações contidas no ambiente virtual. (HEIMANN, 2012)

Apoiado por tecnologias, o design instrucional admite mecanismos de efetiva contextualização, caracterizados por: maior personalização aos estilos e ritmos individuais de aprendizagem; adaptação às características institucionais e regionais; atualização a partir de feedback constante; acesso a informações e experiências externas à organização de ensino; possibilidade de comunicação entre os agentes do processo (professores, alunos, equipe técnica e pedagógica, comunidade); e monitoramento automático da 
construção individual e coletiva de conhecimentos. (FILATRO e PICONEZ, 2007)

As metodologias de desenvolvimento de materiais educacionais devem contemplar princípios pedagógicos, visando estruturar e atender as necessidades do processo de ensino e aprendizagem, tornando o processo educacional mais colaborativo, interativo, atraente e dinâmico (HEIMANN, 2012).

A divisão do processo de design instrucional em fases é conhecida como o modelo ADDIE, amplamente aplicado no ensino online, caracteriza-se por ser um modelo que possibilita visualizar a ação educativa como um todo.

As fases de análise, design, desenvolvimento, implementação e avaliação, não são independentes, mas se constituem de sobreposições de etapas que representam uma rede que se conectam umas às outras. (FILATRO, 2004).

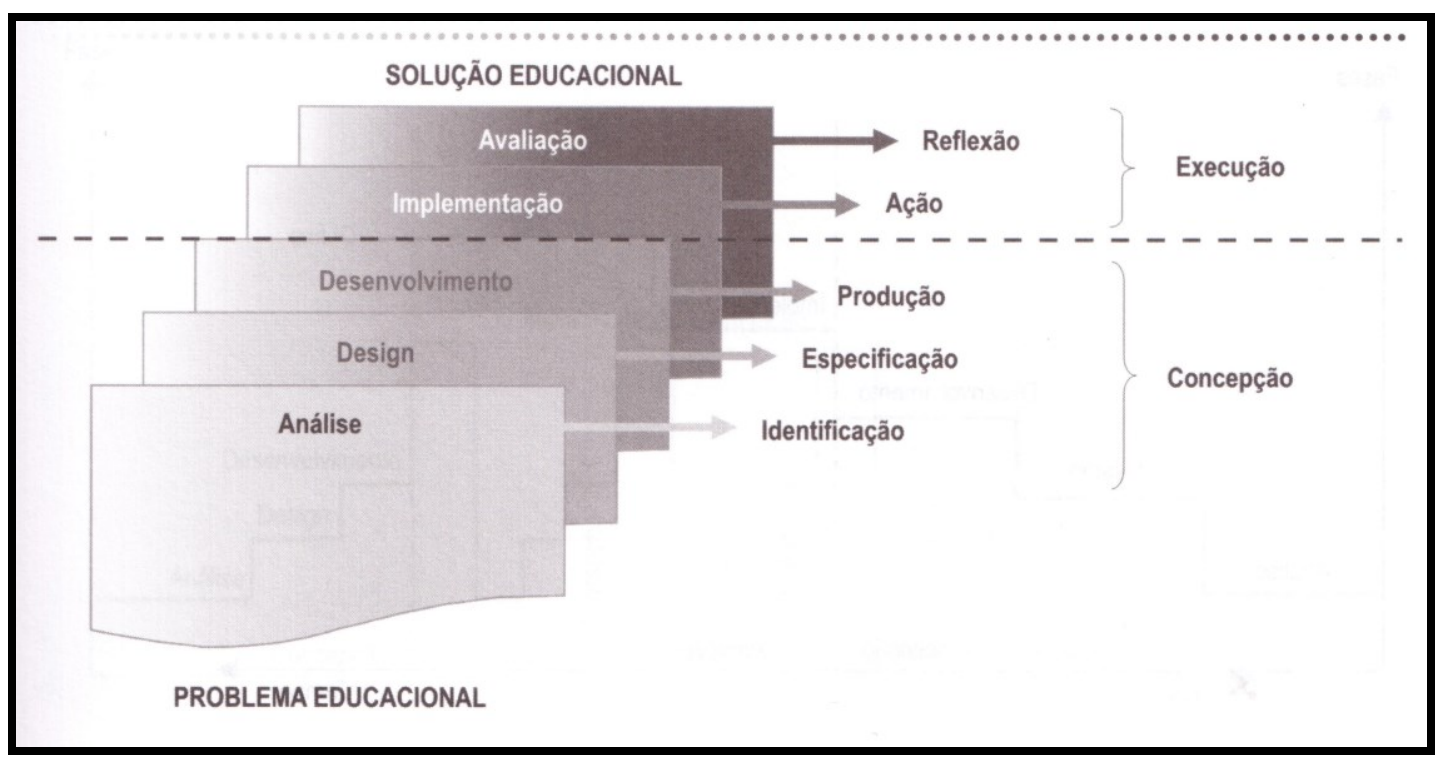

Figura 1: Fases do processo de design instrucional do modelo Addie. (FILATRO, 2008)

Diante dessa perspectiva, Filatro (2008) define as fases de análise, design, desenvolvimento, implementação e avaliação como: 


\subsection{FASE DE ANÁLISE}

$\mathrm{Na}$ perspectiva do DIC, a fase de análise consiste em entender o problema educacional e projetar uma solução pertinente, que deve ser aprimorada constantemente. É a etapa inicial do desenvolvimento de um sistema de aprendizagem online.

Um aspecto relevante do design instrucional e que precede a construção da matriz da unidade de aprendizagem é a presença do conceito de análise contextual. Assim, considerando a metodologia de Andrea Filatro (2008), a análise contextual consiste em examinar os diferentes níveis de contexto e identificar as necessidades de aprendizagem através da caracterização do público-alvo, restrições técnicas, administrativas e culturais.

Os contextos podem ser divididos em:

- Contexto de orientação: anterior à aprendizagem, influencia a motivação futura do aluno e o prepara para aprender;

- Contexto de aprendizagem: determinado pela situação didática em si (curso, programa, aula), envolve as pessoas e os recursos físicos, sociais e simbólicos reunidos em dado momento com o objetivo de aprender;

- Conceito de transferência: posterior à aprendizagem, engloba o ambiente ou a situação em que aprendizagem é aplicada.

\subsection{FASE DE DESIGN}

No design é especificado o cenário, a concepção pedagógica a ser utilizada para fundamentar a aprendizagem do aluno, bem como serão definidos os objetivos de aprendizagem, conteúdos, estratégias, estrutura de navegação e apresentação. (HEIMANN, 2012) 
Essa fase do design instrucional caracteriza-se por ser mais duradoura e trabalhosa, abrange o planejamento e o design propriamente dito, com o mapeamento e sequenciamento do conteúdo, a definição das estratégias e atividades de aprendizagem para alcançar os objetivos traçados, a seleção de mídias e ferramentas mais apropriadas e a descrição dos materiais que deverão ser produzidos.

Em alguns contextos educacionais de grandes instituições, essa fase pode ser desenvolvida por uma equipe multiprofissional, orientada para o alcance dos objetivos educacionais propostos.

\subsection{FASE DE DESENVOLVIMENTO}

O desenvolvimento instrucional compreende a produção e a adaptação de recursos e materiais didáticos impressos e/ou digitais, a parametrização de ambientes virtuais e a preparação dos suportes pedagógico, tecnológico e administrativo.

A fase de desenvolvimento demanda um maior tempo para selecionar e editar o material apropriado, é portanto, um exercício contínuo de adequação do material selecionado à carga horária do curso ou da aula virtual.

A adesão à padrões de catalogação de metadados, na fase de desenvolvimento, é essencial para que os objetos de aprendizagem possam ser utilizados em outras unidades ou outros cursos.

\subsection{FASE DE IMPLEMENTAÇÃO}

A implementação constitui a situação didática propriamente dita, e no aprendizado eletrônico pode ser dividida em duas fases: a de publicação e a de execução.

Disponibilizar o acesso ao ambiente e as unidades de aprendizagem aos alunos caracteriza a fase de publicação. Isso 
envolve o carregamento de arquivos no ambiente virtual, configuração de ferramentas, datas limites de tarefas e definição de papéis e tipos de permissões de acesso.

É na fase de execução que os alunos realizam as atividades propostas, navegam pelo ambiente, interagem com os recursos, ferramentas, educadores e outros alunos.

\subsection{FASE DE AVALIAÇÃO}

Como definição mais ampla da fase de avaliação, pode-se entender que nela avalia-se tanto a solução educacional apresentada quanto os resultados de aprendizagem dos alunos, que, em última instância, refletirão a adequação do design instrucional.

A fase de avaliação no design instrucional deve permear todo o processo de construção da unidade de aprendizagem, através dessa ação realiza-se diagnósticos da adequação do conteúdo aos sujeitos e os conhecimentos e habilidades necessários.

Assim como em qualquer processo educacional, a concepção de avaliação está atrelada à abordagem pedagógica utilizada.

O designer instrucional deve acompanhar os resultados das atividades e da unidade de aprendizagem como um todo, registrando e analisando os dados, dessa maneira aprendendo com o sucesso e o fracasso de determinada estratégia, portanto, aperfeiçoando a experiência do design instrucional em futuras aulas virtuais ou cursos.

\subsection{MATRIZ DE DESIGN INSTRUCIONAL}

A matriz de design instrucional é o principal produto do processo de design instrucional. Em outras palavras a matriz é a proposição que permitirá uma visão panorâmica de cada unidade de aprendizagem, onde são elencados os objetivos, conteúdos, 
ferramentas e mecanismos de avaliação que serão disponibilizados aos usuários para que estes realizem as tarefas propostas e construam seu processo de aprendizagem. Esta ferramenta ainda permite a verificação dos níveis de interação professor-aluno propostos bem como o tempo de duração da unidade de aprendizagem (FILATRO, 2008)

A descrição das unidades de aprendizagem se torna mais clara com a construção da matriz, englobando todos os itens: Objetivos, papéis, atividades, carga horária, ferramentas, conteúdos e avaliação.

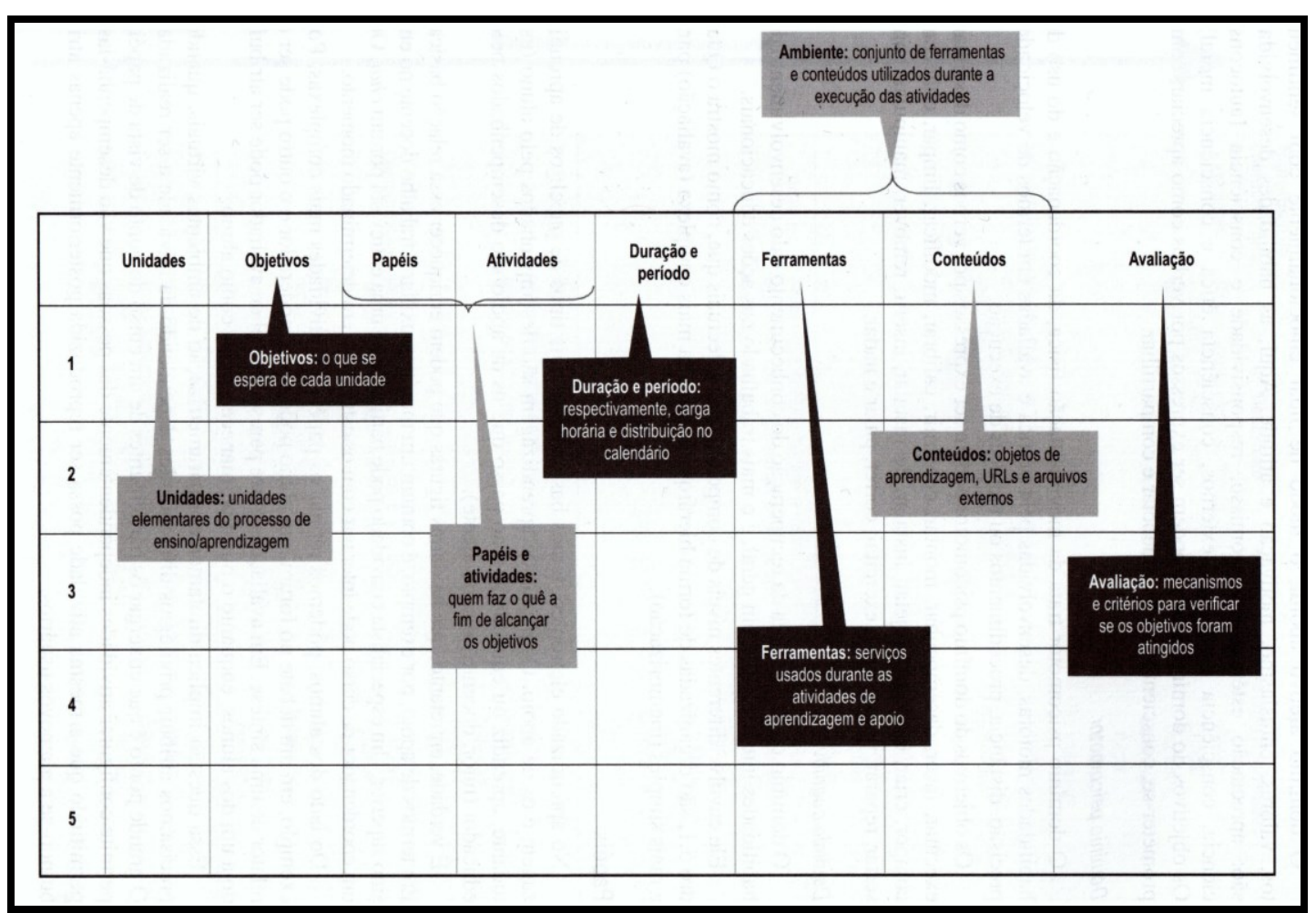

Figura 2: Elementos da matriz de design instrucional. (FILATRO, 2008)

Objetivos: são listados os objetivos educacionais da aula, o que se espera que o aluno seja capaz de realizar ao fim da aula

Papéis e atividades: define quem são os responsáveis por atividades dentro da unidade para que os objetivos sejam alcançados. 
Carga horária: refere-se à duração da unidade de aprendizagem, no caso deste estudo, a duração foi estipulada anteriormente para 4 horas de aula.

Ferramentas: itens disponibilizados pelo ambiente virtual ou selecionados pelo designer.

Conteúdos: Todos os objetos de aprendizagem utilizados.

Avaliação: Mecanismos e critérios explícitos para que se verifique se os objetivos foram alcançados.

Dentro do design de unidades de aprendizagem, conteúdos e ferramentas são organizados em um ambiente. Segundo Filatro (2008), o ambiente pode ser definido como um conjunto de ferramentas e conteúdos utilizados durante a execução das atividades.

Dentro deste projeto, conteúdos e ferramentas foram considerados conforme as definições:

- Conteúdos incluem amplos recursos de aprendizagem digitais, como páginas web, arquivos em formatos variados (doc, xls, ppt, pdf) e objetos de aprendizagem.

Existem diversos conceitos que definem o termo objetos de aprendizagem, o mais comumente citado é o de Wiley (2000) que os define como qualquer recurso digital que pode ser reutilizado para dar suporte à aprendizagem e distribuído pela rede. Existem muitas oportunidades para objetos de aprendizagem tornarem-se ferramentas produtivas em facilitar a aprendizagem.

- As ferramentas do aprendizado incluem serviços ou funcionalidades de comunicação (e-mail, fórum, chat), aplicativos para edição de textos, apresentação de slides e manipulação de planilhas eletrônicas e mecanismos de busca e organização do 
conhecimento, além de recursos de monitoramento e avaliação (FILATRO, 2008).

Evidencia-se que o significado dos conceitos aqui utilizados, seguem especificamente o referencial do modelo de Design Instrucional. Portanto, ao citar conteúdo, por exemplo, refere-se ao conteúdo dentro dos objetos de aprendizagem e não ao pensamento de conteúdo programático dentro da lógica pedagógica de um plano de aula. 


\section{PROCEDIMENTO METODOLÓGICO}

\subsection{TIPO DE PESQUISA}

Trata-se de uma pesquisa exploratório-descritiva, do tipo documental.

Para Silva e Menezes (2001) a pesquisa descritiva se propõe a descrever as características de determinado fenômeno ou o estabelecimento de relações entre variáveis. Envolve o uso de técnicas padronizadas de coleta de dados: questionário e observação sistemática.

A pesquisa documental corresponde a toda informação coletada, seja de forma oral, escrita ou visualizada. Abrange a coleta, classificação, seleção difusa e utilização de toda espécie de informações, como também as técnicas e os métodos que facilitam a sua busca e identificação. (FACHIN, 2006)

\subsection{CENÁRIO DO ESTUDO}

O estudo foi desenvolvido na Escola de Enfermagem da Universidade de São Paulo (EEUSP), no curso de Licenciatura em Enfermagem, na disciplina ENO0336 - Seminários de Educação: Vivenciando o Processo de Educação na Enfermagem, oferecida pelo Departamento de Orientação Profissional.

Possui carga horária total de 30 horas e é realizada semestralmente, ocorre concomitante com a última disciplina do curso de licenciatura, ENO0436 - Metodologia do Ensino em Enfermagem II.

São objetivos gerais da disciplina: 
- Articular de forma crítica os conhecimentos da área de educação em saúde com o processo educacional profissionalizante de enfermagem, a partir das vivências dos alunos pautadas em situações práticas de aprendizado;

- Integrar experiências educativas às ações no âmbito da atenção à saúde.

\subsection{OBJETOS DO ESTUDO}

A pesquisa teve como objetos de estudo 33 aulas virtuais construídas pelos licenciandos de enfermagem e inseridas na plataforma Moodle no ano de 2012.

O acesso ao Moodle é livre ao público, entretanto o acesso à disciplina ENO0336 é restrito aos alunos que estiveram matriculados. A senha de acesso foi fornecida aos participantes.

Os alunos construíram as aulas virtuais de acordo com as orientações realizadas e disponibilizadas no ambiente virtual e enviaram os arquivos por e-mail. $\mathrm{O}$ upload dos arquivos à plataforma foi realizado pela pesquisadora deste estudo e aluna do Programa PAE da licenciatura, para que o conteúdo fosse organizado somente por um perfil de administrador.

Para a elaboração das aulas virtuais, foram utilizados recursos próprios dos alunos sem a necessidade de aquisição de material extra, além do que já utilizavam para o preparo de suas atividades e aulas do curso da licenciatura.

No ambiente virtual de aprendizagem também foram disponibilizados fórum de dúvidas e notícias, tutorial da plataforma Moodle, diário de avaliação da experiência do curso, instruções gerais e critérios de avaliação da aula virtual. 
$\mathrm{Na}$ perspectiva do gerenciamento da disciplina ENO0336, as aulas virtuais dos alunos foram avaliadas segundo critérios construídos pelas docentes (APÊNDICE B) e foi atribuída uma nota a cada aluno, contabilizada como única atividade para a aprovação do licenciando na disciplina.

\subsection{PROCEDIMENTO PARA COLETA DE DADOS}

A coleta de dados ocorreu por meio da análise documental das aulas desenvolvidas pelos licenciandos e recuperadas no ambiente virtual de aprendizagem.

O acesso aos documentos se efetuou na plataforma Moodle, página da disciplina ENO0336, ambiente onde as aulas virtuais foram reunidas. Acesso através dos seguintes passos:

- Acesso ao Moodle no endereço:

http://moodle.redealuno.usp.br

- Preenchimento de usuário e senha

- Acesso à disciplina: ENO0336 - Seminários de Educação 2012.

- Acesso às 33 aulas virtuais dos licenciandos.

Os dados foram armazenados em banco de dados informatizado, e posteriormente submetidos à análise e tabulação.

\subsection{ANÁLISE DOS DADOS}

As aulas virtuais foram analisadas segundo o modelo do Design Instrucional Contextualizado (DIC). 
O design de unidades de aprendizagem é utilizado neste projeto através da construção de matrizes para cada aula virtual do licenciando, portanto, foram construídas 33 matrizes individuais. Por meio da matriz teremos uma visão panorâmica de cada unidade de aprendizagem, bem como de suas potencialidades ou fragilidades.

A descrição quantitativa do número de ferramentas utilizadas, por exemplo a quantidade de fóruns e slides em PowerPoint, será apresentada através da tabulação dos dados em banco de dados e posterior produção de gráficos. Também foi verificada a adequação aos requerimentos mínimos da aula virtual bem como a avaliação da qualidade pedagógica e técnica das aulas virtuais.

Para que o aluno da licenciatura da EEUSP fosse bem sucedido na construção da sua aula virtual, esperava-se que ele utilizasse conhecimentos prévios construídos ao longo do curso, fosse capaz de organizar e planejar o conteúdo de forma criativa, adequasse o tema da aula para o público alvo e propusesse atividades que tornassem possível o acompanhamento do desempenho do aluno no ambiente virtual.

Uma ressalva importante é que nesta pesquisa os licenciandos de enfermagem construíram as aulas virtuais mas não chegaram a implementar aos alunos da educação profissional técnica de nível médio em enfermagem, pois esse não era o objetivo da disciplina. Dessa maneira, torna-se pertinente a análise das aulas virtuais de acordo somente com as fases de concepção do design instrucional (análise, design e desenvolvimento), sendo que o nível de execução (fases de implementação e avaliação) não será contemplado no presente estudo. 


\subsection{CONSIDERAÇÕES ÉTICAS}

O projeto de pesquisa foi submetido à apreciação da Diretoria, à Comissão de Pesquisa e ao Comitê de Ética em Pesquisa da Escola de Enfermagem da USP e foi aprovado, sob processo número 403.389/2013/CEP/EEUSP - SISNEP CAAE: 18557713.8.0000.5392, em 23 de setembro de 2013 (ANEXO A) .

O procedimento de coleta de dados foi iniciado após aprovação do estudo no Comitê de Ética em Pesquisa e autorização da Escola de Enfermagem da Universidade de São Paulo.

Ressalta-se ainda que, quando houve necessidade de transcrever registros dos licenciandos coletados no ambiente virtual, o anonimato dos alunos foi preservado através da substituição de seus nomes por letras seguidos de numeração arábica crescente. 
5 RESULTADOS 


\section{RESULTADOS}

Os alunos da licenciatura produziram 33 aulas virtuais abordando diversos temas da área da saúde e pertinentes à educação profissional técnica de nível médio em enfermagem. Os temas foram definidos pelos próprios licenciandos que, durante a carga horária de prática em campo, ministraram aulas aos auxiliares e técnicos de enfermagem em formação em um momento anterior a esta atividade de desenvolverem as aulas virtuais.

Todo o conteúdo produzido foi inserido na plataforma Moodle, página da disciplina ENO 0336 - Seminários de Educação: Vivenciando o processo de educação na enfermagem.

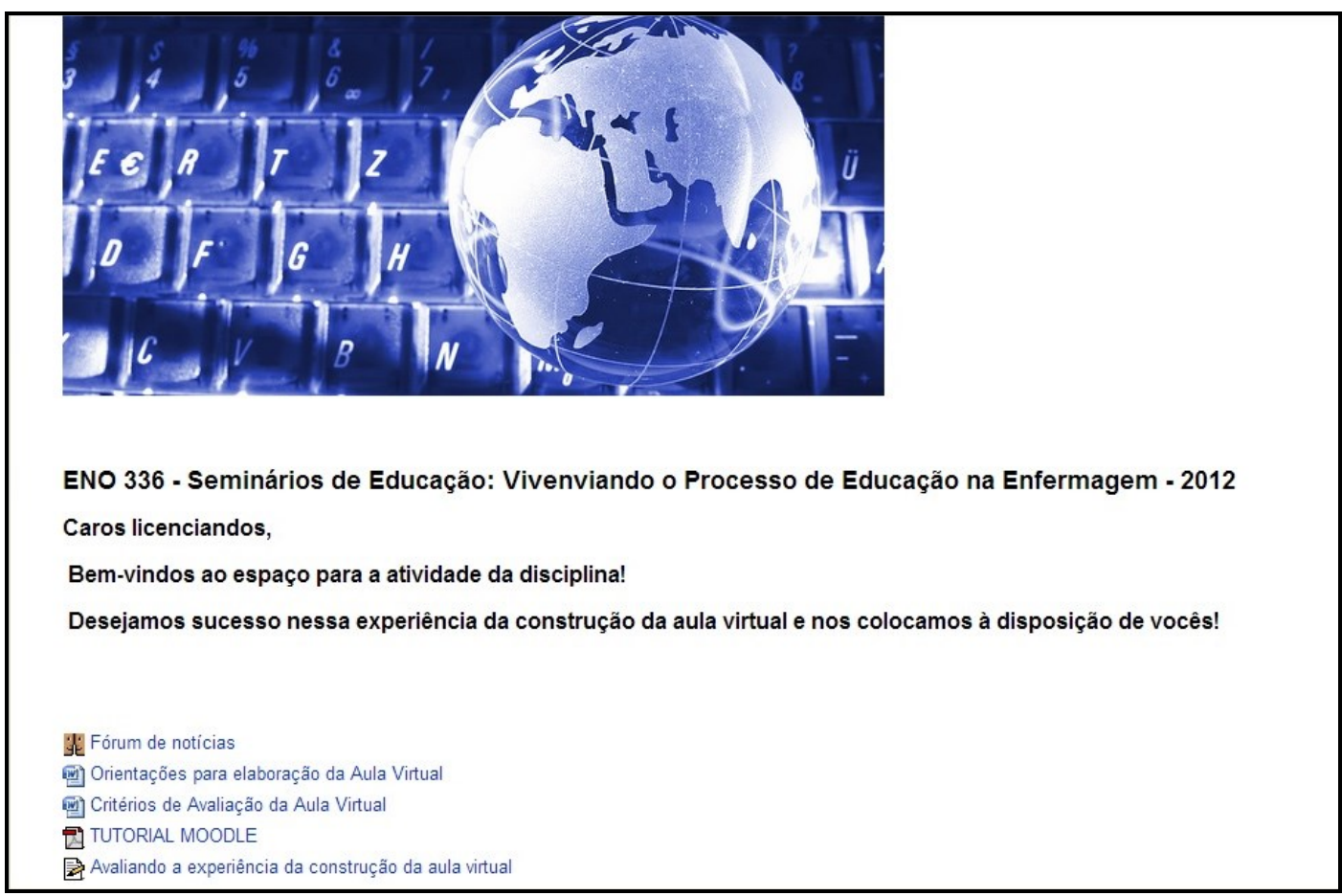

Figura 3: Página Inicial da disciplina no Moodle (Fonte: Moodle EEUSP)

No início da página também foi disponibilizado um fórum de notícias, orientações para elaboração da aula virtual (APÊNDICE A), critérios de avaliação da aula virtual (APÊNDICE B), um tutorial do Moodle e uma ferramenta diário para a avaliação da experiência da construção da aula virtual pelo licenciando. 
O fórum de notícias é um eficiente canal de comunicação entre docentes e alunos, foram contemplados tópicos sobre prazos e dúvidas acerca da atividade proposta.

As orientações para a elaboração da aula virtual que os licenciandos receberam guiou todo o processo de construção do material educacional no ambiente virtual, como se segue:

Para realizar essa atividade você precisará:

- Escolher uma das aulas ministradas por você no Curso de Licenciatura.

- Construir, a partir desse conteúdo teórico, sua aula virtual.

- Organizar a aula através de uma rota de aprendizagem.

- Como requisitos mínimos a aula deverá conter: objetivos, critérios de avaliação, um objeto virtual de aprendizagem, uma ou mais atividades para nota e bibliografia de apoio.

- Enviar a rota de aprendizagem, os arquivos, objetos de aprendizagem e links para Vanessa (vanessa.lopes.munhoz@usp.br) até o dia 22 de Outubro.

- A aula será disponibilizada no Moodle pela Vanessa.

- Apresentar a estrutura da aula no dia 01 de Novembro.

Obs: Para que você possa escolher ferramentas do Moodle para utilizar na aula disponibilizamos um tutorial sobre 0 mesmo explicando as ferramentas disponíveis.

Figura 4: Destaque das orientações para elaboração da aula virtual (Autoria: Claudia Prado e colaboradores; 2012)

Os critérios de avaliação da aula virtual foram construídos pelos docentes da disciplina e serviram de apoio para avaliar o desempenho dos alunos somente no contexto desta disciplina da licenciatura. Portanto, esses critérios não foram utilizados para o alcance do objetivo deste projeto. 
O ambiente virtual de aprendizagem Moodle permite que o design seja realizado diretamente na ferramenta. $O$ ambiente proporciona ao designer diversas opções de configuração visual da página e inúmeras possibilidades de ferramentas, como por exemplo o fórum, chat, envio de tarefas e diário. A flexibilidade de criação também concretiza-se através do upload de links da internet e arquivos em diversos formatos. O idealizador da aula virtual especifica o cenário, abordagem pedagógica, objetivos, conteúdos, fluxo de atividades, formas de avaliação, entre outros.

Os alunos da licenciatura foram contextualizados com a realidade dos educandos para o qual prepararam as aulas virtuais, uma vez que, durante a carga horária de prática em campo, conhecem a instituição e os alunos da educação profissional técnica de nível médio em enfermagem. Também tiveram a oportunidade de conhecer o projeto político-pedagógico da instituição e acompanham auxiliares e técnicos de enfermagem em campo, ministram aulas para essas mesmas turmas, sempre supervisionados por docentes do ensino profissionalizante. Conhecer o perfil dos alunos é um processo e não uma etapa única, esse processo torna-se essencial para a definição de estratégias pedagógicas.

O aluno da licenciatura, na posição temporária de "designer instrucional" (devido à atividade que Ihes foi solicitada) têm, nesse contexto, um "briefing" ou uma ideia inicial do que pode ser alcançado com a ação educacional que propõe através da aula virtual.

Dessa maneira, as aulas desenvolvidas são pertinentes ao perfil dos alunos da educação profissional técnica de nível médio em enfermagem para o qual foram idealizadas devido à qualidade do conteúdo de enfermagem presente. Também são pertinentes ao ambiente virtual de aprendizagem Moodle devido à escolha de 
recursos tecnológicos disponíveis e adequados ao ensino online na plataforma.

[...] O docente de Enfermagem tem autonomia para incluir, como ferramenta dos processos de ensinoaprendizagem, novas tecnologias da informação e comunicação, a depender da disponibilização institucional e da capacitação tecnológica que possui para operá-las. (PRADO et al, 2011).

Agregar o valor da experiência no uso de TDIC, mesmo que inicial, e estabelecer contato com novas estratégias de ensino na formação do docente de enfermagem potencializa o desempenho profissional do educador.

O educador que é submetido a uma nova estratégia de ensino com o uso de tecnologia, sendo essa uma experiência positiva, tende a reproduzi-la no seu exercício profissional. Esse processo em cascata é favorável a modernização e progresso do ensino em enfermagem.

\subsection{A CONSTRUÇÃO DAS MATRIZES}

Para a construção da matriz de design instrucional, os itens de cada aula foram categorizados segundo as ferramentas do Moodle que mais se assemelhavam com a atividade proposta pelo licenciando. Por exemplo: Itens presentes na matriz, como objetivos e atividades, foram retirados da rota de aprendizagem construída pelos próprios alunos.

A dificuldade para o agrupamento dos dados na construção da matriz se deu, em parte, devido à dificuldade do futuro docente em nomear corretamente a atividade educativa proposta. Verificou-se a generalização das palavras questionário, tarefa e exercício, por exemplo. Surge então o questionamento se o futuro docente sabe nomear corretamente as atividades que ele mesmo propõe no contexto educacional. 
Devido à essa dificuldade dos alunos, em nomear corretamente a atividade selecionada, durante a análise dos resultados a pesquisadora deste estudo utilizou o mesmo critério para todas as aulas.

O critério de agrupamento dos dados para a construção da matriz seguiu rigorosamente conceitos da teoria de design instrucional e definições da matriz segundo Filatro (2008).

O conjunto obtido através das 33 matrizes possibilitaram uma visão ampla e elucidativa de como o futuro docente de enfermagem reflete e organiza o material didático em um ambiente virtual de aprendizagem. 


\section{MATRIZ AULA 1}

\begin{tabular}{|c|c|}
\hline UNIDADE & Intoxicações exógenas \\
\hline OBJETIVOS & $\begin{array}{l}\text { 1. Conhecer as principais fontes de intoxicações do homem e seus sinais e sintomas } \\
\text { 2. Compreender os mecanismos de ação de algumas dessas intoxicações } \\
\text { 3. Conhecer o tratamento indicado, os cuidados de enfermagem e apoio ao } \\
\text { acompanhante } \\
\text { 4. Relacionar o conteúdo exposto num exercício proposto ao final da aula }\end{array}$ \\
\hline PAPÉIS & $\begin{array}{l}\text { 1. Apoio } \\
\text { 2. Aprendizagem }\end{array}$ \\
\hline ATIVIDADES & $\begin{array}{l}\text { 1.Assistir aos dois vídeos selecionados para a aula } \\
\text { 2.Pesquisar, num site de credibilidade, a epidemiologia das intoxicações na cidade } \\
\text { de São Paulo. } \\
\text { 3.Acessar o arquivo, com alguns dos principais tipos de intoxicações, suas } \\
\text { manifestações clínicas, tratamento e cuidados de enfermagem. } \\
\text { 4.Ler artigo } \\
\text { 5.Responder três perguntas } \\
\text { 6.Postar a atividade no local reservado } \\
\text { 7.Enviar sua autoavaliação } \\
\text { 8.Enviar a avaliação da aula com sugestões e críticas }\end{array}$ \\
\hline CARGA HORÁRIA & $04 \mathrm{hs}$ \\
\hline FERRAMENTAS & $\begin{array}{l}\text { Vídeos } \\
\text { Apresentação } \\
\text { Artigo científico } \\
\text { Pesquisa online } \\
\text { Questionário } \\
\text { Fórum virtual } \\
\text { Avaliação }\end{array}$ \\
\hline CONTEÚDO & $\begin{array}{l}\text { Rota de aprendizagem em Powerpoint } \\
\text { Vídeo no Youtube } \\
\text { Slides da aula em Powerpoint } \\
\text { Artigo em PDF } \\
\text { Tarefa de questionário } \\
\text { Fórum privado para autoavaliação } \\
\text { Diário de avaliação da aula } \\
\text { Fórum para contato com professor } \\
\text { Referências bibliográficas }\end{array}$ \\
\hline AVALIAÇÃO & $\begin{array}{l}\text { Critérios de avaliação da tarefa expostos } \\
\text { Avaliação da tarefa } \\
\text { Autoavaliação } \\
\text { Avaliação da aula }\end{array}$ \\
\hline
\end{tabular}




\section{MATRIZ AULA 2}

\begin{tabular}{|c|c|}
\hline UNIDADE & Assistência de Enfermagem no pré e pós operatório \\
\hline OBJETIVOS & $\begin{array}{l}\text { 1. Conceituar período perioperatório. } \\
\text { 2. Identificar as necessidades e os cuidados de enfermagem específicos da } \\
\text { assistência pré-operatória. } \\
\text { 3. Identificar as necessidades e os cuidados de enfermagem específicos da } \\
\text { assistência pós-operatória. } \\
\text { 4. Sensibilizar-se para os aspectos psicosocioespiritual dos pacientes em situação pré } \\
\text { e pós-operatória }\end{array}$ \\
\hline PAPÉIS & $\begin{array}{l}\text { 1. Apoio } \\
\text { 2. Aprendizagem }\end{array}$ \\
\hline ATIVIDADES & $\begin{array}{l}\text { 1. Postar sua contribuição no fórum "Minhas experiências" e interaja com os } \\
\text { colegas } \\
\text { 2.Assistir a apresentação da aula } \\
\text { 3.Ler e responder a tarefa "Meus primeiros cuidados" } \\
\text { 4.Veja e analise a imagem selecionada } \\
\text { 5. Poste sua contribuição e interaja com os colegas no fórum "O que eu vejo" } \\
\text { 6.Relate a sua opinião e percepção e dessa aula na ferramenta "Avaliando essa } \\
\text { experiência" } \\
\text { 7.Acesse a bibliografia de referência }\end{array}$ \\
\hline CARGA HORÁRIA & $04 \mathrm{hs}$ \\
\hline FERRAMENTAS & $\begin{array}{l}\text { Apresentação } \\
\text { Tarefa } \\
\text { Imagem } \\
\text { Fórum virtual } \\
\text { Avaliação }\end{array}$ \\
\hline CONTEÚDO & $\begin{array}{l}\text { Rota de Aprendizagem em PDF } \\
\text { Como você será avaliado em PDF } \\
\text { Fórum virtual - Minhas Experiências } \\
\text { Slides - da aula em PDF } \\
\text { Tarefa Meus Primeiros Cuidados em PDF } \\
\text { Tarefa Meus Primeiros Cuidados } \\
\text { Fórum virtual - O que eu vejo } \\
\text { Diário - Avaliando essa experiência } \\
\text { Documento Word - Orientações Biblioteca Virtual } \\
\text { Base de Dados - Bibliografia de Referência } \\
\text { Fórum Virtual - Dúvidas }\end{array}$ \\
\hline AVALIAÇÃo & $\begin{array}{l}\text { Critérios de avaliação da tarefa expostos } \\
\text { Avaliação da tarefa e fórum } \\
\text { Avaliação da aula }\end{array}$ \\
\hline
\end{tabular}




\section{MATRIZ AULA 3}

\begin{tabular}{|c|c|}
\hline UNIDADE & Via Parenteral \\
\hline OBJETIVOS & $\begin{array}{l}\text { 1. conhecer as técnicas de preparo e administração de medicamentos pelas vias } \\
\text { intradérmica, intramuscular, subcutânea e intravenosa } \\
\text { 2. aplicá-las corretamente na prática } \\
\text { 3. realizar esses procedimentos com competência }\end{array}$ \\
\hline PAPÉIS & $\begin{array}{l}\text { 1. Apoio } \\
\text { 2. Aprendizagem }\end{array}$ \\
\hline ATIVIDADES & $\begin{array}{l}\text { 1.Fazer uma revisão da anatomia por meio do material disponibilizado. } \\
\text { 2.Assistir a apresentação da aula "Técnica de preparo e administraçãoo - Via } \\
\text { Parenteral" } \\
\text { 3.Postar sua contribuição no Fórum "Complicações da Terapia Intravenosa" } \\
\text { 4. Fazer e postar a tarefa proposta em "Montando um vídeo demonstrativo" } \\
\text { 5.Assistir aos vídeos propostos e postar comentário no Fórum "Comentários acerca } \\
\text { dos vídeos" } \\
\text { 6. Avaliar a aula clicando no link "Avaliação da aula" }\end{array}$ \\
\hline CARGA HORÁRIA & 04hs \\
\hline FERRAMENTAS & $\begin{array}{l}\text { Imagens } \\
\text { Apresentação } \\
\text { Fórum virtual } \\
\text { Vídeos } \\
\text { Avaliação }\end{array}$ \\
\hline CONTEÚDO & $\begin{array}{l}\text { Rota de Aprendizagem } \\
\text { Materiais para revisão Anatomia } \\
\text { Slides da Aula } \\
\text { Fórum Virtual: Complicações da Terapia Intravenosa } \\
\text { Fórum Virtual: Montando um vídeo demonstrativo } \\
3 \text { Vídeos no Youtube } \\
\text { Fórum - Comentários acerca dos vídeos } \\
\text { Referências Bibliográficas }\end{array}$ \\
\hline AVALIAÇÃO & $\begin{array}{l}\text { Critérios de avaliação da tarefa expostos } \\
\text { Avaliação da tarefa } \\
\text { Avaliação da aula }\end{array}$ \\
\hline
\end{tabular}




\section{MATRIZ AULA 4}

\begin{tabular}{|c|c|}
\hline UNIDADE & Transplante \\
\hline OBJETIVOS & $\begin{array}{l}\text { 1. Aprender aspectos gerais relacionados aos transplantes } \\
\text { 2. Compreender a importância dos cuidados de enfermagem dispensados a } \\
\text { pacientes transplantados, doadores vivos e doadores falecidos nos diferentes tipos } \\
\text { de transplantes de órgãos e tecidos. }\end{array}$ \\
\hline PAPÉIS & $\begin{array}{l}\text { 1. Apoio } \\
\text { 2. Aprendizagem }\end{array}$ \\
\hline ATIVIDADES & $\begin{array}{l}\text { 1.Participar do fórum "O que sei e o que quero saber"; } \\
\text { 2.Assistir às apresentações Transplante 1, } 2 \text { e 3; } \\
\text { 3.Assistir ao trailer do filme "Uma prova de amor"; } \\
\text { 4.Entrar no chat (online em data e hora a serem confirmadas) e participar da } \\
\text { atividade proposta pelo moderador; } \\
\text { 5.Assistir à apresentação Transplante 4; } \\
\text { 6.Assistir aos vídeos sobre Morte Encefálica; } \\
\text { 7.Assistir à apresentação Transplante } 5 \text { e 6; } \\
\text { 8.Assistir aos vídeos selecionados sobre diferentes transplantes; } \\
\text { 9.Ler um dos textos disponíveis no ambiente virtual sobre cuidados de enfermagem } \\
\text { ao paciente transplantado; } \\
\text { 10. Participar do fórum "Enfermagem x Transplante" }\end{array}$ \\
\hline CARGA HORÁRIA & 04hs \\
\hline FERRAMENTAS & $\begin{array}{l}\text { Fórum virtual } \\
\text { Vídeos } \\
\text { Apresentação } \\
\text { Artigo científico } \\
\text { Chat } \\
\text { Avaliação }\end{array}$ \\
\hline CONTEÚDO & $\begin{array}{l}\text { Rota de aprendizagem } \\
\text { Fórum Virtual: O que sei e o que quero saber } \\
\text { Slides da aula em Powerpoint } \\
\text { Vídeos no Youtube } \\
\text { Chat Virtual } \\
\text { Artigo em PDF } \\
\text { Fórum Virtual: Enfermagem X Transplante } \\
\text { Fórum de Dúvidas } \\
\text { Referências bibliográficas }\end{array}$ \\
\hline AVALIAÇÃO & $\begin{array}{l}\text { Critérios de avaliação expostos } \\
\text { Avaliação do chat e fóruns }\end{array}$ \\
\hline
\end{tabular}




\section{MATRIZ AULA 5}

\begin{tabular}{|c|c|}
\hline UNIDADE & $\begin{array}{c}\text { Doenças Infecto-contagiosas: hanseníase, rotavírus, difteria e } \\
\text { tétano }\end{array}$ \\
\hline OBJETIVOS & $\begin{array}{l}1 \text { Conhecer algumas das doenças infecto-contagiosas } \\
2 \text { Saber as formas de transmissão de cada doença } \\
3 \text { Saber identificar sinais e sintomas de cada doença } \\
4 \text { Saber os tratamentos e formas de prevenção de cada doença } \\
5 \text { Conhecer o calendário vacinal das doenças apresentadas }\end{array}$ \\
\hline PAPÉIS & $\begin{array}{l}\text { 1. Apoio } \\
\text { 2. Aprendizagem }\end{array}$ \\
\hline ATIVIDADES & $\begin{array}{l}\text { 1.Assistir a aula "Doenças Infecto-contagiosas" } \\
\text { 2.Leia o artigo "Diarréia e Rotavírus" } \\
\text { 3.Leia o artigo "Vacinação dos viajantes: experiência do Ambulatório dos Viajantes } \\
\text { do HCFMUSP" } \\
\text { 4.Veja o vídeo "Hanseníase - Projeto Homem Virtual" } \\
\text { 5.Construa uma tabela contendo: sinais e sintomas, formas de transmissão e } \\
\text { prevenção de cada doença apresentada } \\
\text { 6.Procure um artigo que aborde a vacinação de uma das doenças estudadas e poste } \\
\text { na nossa Biblioteca Virtual. Justifique a sua escolha e relate o que esse artigo } \\
\text { acrescentou em seu conhecimento } \\
\text { 7.Vá até o fórum "Avaliando essa experiência" e relate suas percepções dessa aula }\end{array}$ \\
\hline CARGA HORÁRIA & $04 \mathrm{hs}$ \\
\hline FERRAMENTAS & $\begin{array}{l}\text { Apresentação } \\
\text { Artigo científico } \\
\text { Vídeos } \\
\text { Pesquisa online } \\
\text { Tarefa } \\
\text { Fórum virtual } \\
\text { Avaliação }\end{array}$ \\
\hline CONTEÚDO & $\begin{array}{l}\text { Rota de aprendizagem em Powerpoint } \\
\text { Slides da aula em Powerpoint } \\
\text { Artigo em PDF } \\
\text { Vídeo no Youtube } \\
\text { Tarefa da tabela com sinais e sintomas } \\
\text { Tarefa do artigo sobre vacinação } \\
\text { Fórum de avaliação da aula } \\
\text { Fórum de dúvidas } \\
\text { Referências bibliográficas }\end{array}$ \\
\hline AVALIAÇÃO & $\begin{array}{l}\text { Critérios de avaliação da tarefa expostos } \\
\text { Avaliação da tarefa } \\
\text { Avaliação da aula }\end{array}$ \\
\hline
\end{tabular}




\section{MATRIZ AULA 6}

\begin{tabular}{|c|c|}
\hline UNIDADE & Marketing Pessoal \\
\hline OBJETIVOS & $\begin{array}{l}\text { 1. Conhecer a influência dos estereótipos históricos vinculados à profissão de } \\
\text { enfermagem; } \\
\text { 2. Identificar a importância e a finalidade do marketing pessoal para o profissional de } \\
\text { enfermagem; } \\
\text { 3. Refletir sobre as responsabilidades individuais para a construção da imagem de } \\
\text { um todo (classe da enfermagem). } \\
\text { 4. Identificar os principais elementos para a construção de um marketing pessoal } \\
\text { favorável. }\end{array}$ \\
\hline PAPÉIS & $\begin{array}{l}\text { 1. Apoio } \\
\text { 2. Aprendizagem }\end{array}$ \\
\hline ATIVIDADES & $\begin{array}{l}\text { 1.Assistir aos dois vídeos selecionados para a aula } \\
\text { 2.entrar no chat e participar da discussão. } \\
\text { 3. ler o texto "Marketing pessoal e social uma necessidade em enfermagem" } \\
\text { 4.Assistir a apresentação de slides: marketing pessoal } \\
\text { 5. Exercício reflexivo - valores, missões, objetivos: desenvolvendo plano de ação. } \\
\text { 6.Responder três perguntas } \\
\text { 7. Realizar a Tarefa } \\
\text { 8. Realizar a avaliação da aula }\end{array}$ \\
\hline CARGA HORÁRIA & 04hs \\
\hline FERRAMENTAS & $\begin{array}{l}\text { Vídeos } \\
\text { Apresentação } \\
\text { Artigo científico } \\
\text { Chat } \\
\text { Tarefa } \\
\text { Avaliação }\end{array}$ \\
\hline CONTEÚDO & $\begin{array}{l}\text { Rota de aprendizagem em Word } \\
\text { Vídeo no Youtube } \\
\text { Questões norteadoras para o chat } \\
\text { Slides da aula em PDF } \\
\text { Artigo em PDF } \\
\text { Exercício reflexivo } \\
\text { Tarefa com caso prático } \\
\text { Diário de avaliação da aula } \\
\text { Referências Bibliográficas }\end{array}$ \\
\hline AVALIAÇÃO & $\begin{array}{l}\text { Critérios de avaliação da tarefa expostos } \\
\text { Avaliação da tarefa } \\
\text { Avaliação da aula }\end{array}$ \\
\hline
\end{tabular}




\section{MATRIZ AULA 7}

\begin{tabular}{|c|c|}
\hline UNIDADE & Bases Imunológicas e Imunobiológicos-Rede de Frio \\
\hline OBJETIVOS & $\begin{array}{l}\text { 1. Objetivo Geral: } \\
\text {-Abranger os aspectos relacionados à Imunologia e os Imunobiológicos. } \\
\text { 2. Objetivos do aluno: } \\
\text {-Compreender o sistema imunológico; } \\
\text {-Conceituar os tipos de imunidade; } \\
\text { - Identificar os princípios do Programa Nacional de Imunização; } \\
\text {-Conhecer sobre conservação dos imunobiológicose a Rede de Frio. }\end{array}$ \\
\hline PAPÉIS & $\begin{array}{l}\text { 1. Apoio } \\
\text { 2. Aprendizagem }\end{array}$ \\
\hline ATIVIDADES & $\begin{array}{l}\text { 1.Assista ao vídeo } \\
\text { 2.Assista a apresentação da aula } \\
\text { 3.Responder o questionário "Vacina é todo dia" e postar respostas. } \\
\text { 4.Participar do fórum "Minha vivência com vacinação". } \\
\text { 5.Acessar "Avaliando essa experiência" e relatar sua percepção dessa aula. } \\
\text { 6.Consulte também o site do Centro de Vigilância Epidemiológica (CVE) }\end{array}$ \\
\hline CARGA HORÁRIA & 04hs \\
\hline FERRAMENTAS & $\begin{array}{l}\text { Vídeos } \\
\text { Apresentação } \\
\text { Artigo científico } \\
\text { Pesquisa online } \\
\text { Questionário } \\
\text { Fórum virtual } \\
\text { Avaliação }\end{array}$ \\
\hline CONTEÚDO & $\begin{array}{l}\text { Rota de aprendizagem em Powerpoint } \\
\text { Vídeo no Youtube } \\
\text { Slides da aula em Powerpoint } \\
\text { Artigo em PDF } \\
\text { Tarefa de questionário - imunobiológicos } \\
\text { Fórum Virtual - Minha vivência com vacinação } \\
\text { Avaliação da aula } \\
\text { Referências bibliográficas }\end{array}$ \\
\hline AVALIAÇÃO & $\begin{array}{l}\text { Critérios de avaliação da tarefa expostos } \\
\text { Avaliação da tarefa } \\
\text { Avaliação da aula }\end{array}$ \\
\hline
\end{tabular}




\section{MATRIZ AULA 8}

\begin{tabular}{|c|c|}
\hline UNIDADE & Saúde Pública \\
\hline OBJETIVOS & $\begin{array}{l}\text { 1. Compreender o processo saúde doença com base nos determinantes sociais; } \\
\text { 2. Conhecer os modelos / políticas de saúde do Brasil. }\end{array}$ \\
\hline PAPÉIS & $\begin{array}{l}\text { 1. Apoio } \\
\text { 2. Aprendizagem }\end{array}$ \\
\hline ATIVIDADES & $\begin{array}{l}\text { 1. Ler o texto: A Saúde e seus Determinantes Sociais } \\
\text { 2. Assistir a apresentação da aula até determinantes sociais; } \\
\text { 3. Acessar o Chat: discussão sobre o processo saúde-doença e determinantes sociais. } \\
\text { 4. Continue a aula a partir das políticas de saúde; } \\
\text { 5. Assistir ao vídeo "Políticas de Saúde no Brasil" } \\
\text { 7. Avaliar esta aula. }\end{array}$ \\
\hline CARGA HORÁRIA & 04hs \\
\hline FERRAMENTAS & $\begin{array}{l}\text { Artigo } \\
\text { Apresentação } \\
\text { Chat online } \\
\text { Vídeo } \\
\text { Avaliação da aula }\end{array}$ \\
\hline CONTEÚDO & $\begin{array}{l}\text { Rota de aprendizagem em Powerpoint } \\
\text { Artigo em PDF } \\
\text { Slides da aula em PPT } \\
\text { Chat } \\
\text { Vídeo no Youtube } \\
\text { Diário de avaliação da aula }\end{array}$ \\
\hline AVALIAÇÃO & Avaliação da aula \\
\hline
\end{tabular}




\section{MATRIZ AULA 9}

\begin{tabular}{|c|c|}
\hline UNIDADE & Tuberculose \\
\hline OBJETIVOS & $\begin{array}{l}\text { Geral } \\
\text { 1. Instrumentar o aluno a assistir o paciente tuberculoso baseado na estratégia } \\
\text { DOTS (tratamento diretamente observado) e busca ativa. } \\
\text { Específicos } \\
\text { 1. Compreender o que é tuberculose e a sua relevância epidemiológica; } \\
\text { 2. Definir a estratégia DOTS; } \\
\text { 3. Definir a busca ativa; } \\
\text { 4. Realizar todas as atividades propostas do ambiente virtual. }\end{array}$ \\
\hline PAPÉIS & $\begin{array}{l}\text { 1. Apoio } \\
\text { 2. Aprendizagem }\end{array}$ \\
\hline ATIVIDADES & $\begin{array}{l}\text { 1. Assistir o vídeo DOTS ROCINHA } \\
\text { 2. Assistir a apresentação TUBERCULOSE } \\
\text { 3. Acessar o fórum e poste a atividade contribuindo com os outros colegas } \\
\text { 4. Ler o estudo de caso - T. B. } \\
\text { 5. Em dupla, poste a tarefa do estudo de caso T. B } \\
\text { 6. Avaliar a aula - Ambiente: Fale Aqui! }\end{array}$ \\
\hline CARGA HORÁRIA & 04hs \\
\hline FERRAMENTAS & $\begin{array}{l}\text { Vídeo } \\
\text { Apresentação } \\
\text { Fórum virtual } \\
\text { Estudo de caso } \\
\text { Tarefa } \\
\text { Avaliação }\end{array}$ \\
\hline CONTEÚDO & $\begin{array}{l}\text { Rota de aprendizagem em Powerpoint } \\
\text { Vídeo no Youtube } \\
\text { Slides da aula em Powerpoint } \\
\text { Fórum virtual sobre a estratégia DOTS } \\
\text { Estudo de caso } \\
\text { Tarefa postada em dupla } \\
\text { Fórum de dúvidas } \\
\text { Diário de avaliação da aula - Ambiente: Fale Aqui! } \\
\text { Bibliografia de apoio }\end{array}$ \\
\hline AVALIAÇÃo & $\begin{array}{l}\text { Critérios de avaliação da tarefa expostos } \\
\text { Avaliação da tarefa e fórum } \\
\text { Avaliação da aula }\end{array}$ \\
\hline
\end{tabular}




\section{MATRIZ AULA 10}

\begin{tabular}{|c|c|}
\hline UNIDADE & $\begin{array}{c}\text { Hemocomponentes e assistência de enfermagem na } \\
\text { terapêutica transfusional }\end{array}$ \\
\hline OBJETIVOS & $\begin{array}{l}\text { 1. Compreender os cuidados de enfermagem à uma terapêutica transfusional } \\
\text { segura; } \\
\text { 2. Relacionar o processo de doação e captação sanguínea com a necessidade de } \\
\text { uma assistência de enfermagem qualificada durante o processo transfusional; } \\
\text { 3. Saber como agir corretamente nas situações de reações transfusionais }\end{array}$ \\
\hline PAPÉIS & $\begin{array}{l}\text { 1. Apoio } \\
\text { 2. Aprendizagem }\end{array}$ \\
\hline ATIVIDADES & $\begin{array}{l}\text { 1. Ler os textos: "Avaliação do conhecimento sobre hemoterapia e segurança } \\
\text { transfusional de } \\
\text { profissionais de Enfermagem" e "RESOLUÇÃO COFEN-306/2006"; } \\
\text { 2. Assistir aos vídeos } \\
\text { 3. Ler a aula "Hemocomponentes e assistência de enfermagem na terapêutica } \\
\text { transfusional" } \\
\text { 4. Realizar os dois estudos de caso propostos no final da aula acima citada e } \\
\text { encaminhe para o email X. } \\
\text { 5. Avalie esta aula no arquivo "word" anexado e envie também para o email acima } \\
\text { citado }\end{array}$ \\
\hline CARGA HORÁRIA & 04hs \\
\hline FERRAMENTAS & $\begin{array}{l}\text { Vídeos } \\
\text { Apresentação } \\
\text { Artigo científico } \\
\text { Estudo de caso } \\
\text { Avaliação }\end{array}$ \\
\hline CONTEÚDO & $\begin{array}{l}\text { Rota de aprendizagem em Powerpoint } \\
\text { Vídeo no Youtube } \\
\text { Slides da aula em PDF } \\
\text { Referências Bibliográficas } \\
\text { Artigo em PDF } \\
\text { Texto online } \\
\text { Estudos de caso } \\
\text { Documento de avaliação da aula }\end{array}$ \\
\hline AVALIAÇÃO & $\begin{array}{l}\text { Avaliação da tarefa } \\
\text { Avaliação da aula }\end{array}$ \\
\hline
\end{tabular}




\section{MATRIZ AULA 11}

\begin{tabular}{|c|c|}
\hline UNIDADE & Drenos \\
\hline OBJETIVOS & $\begin{array}{l}\text { 1. Discorrer sobre o que são drenos, quais tipos existem e dar exemplos. } \\
\text { 2. Apontar possíveis complicações com drenos. } \\
\text { 3. Identificar, em linhas gerais, os principais cuidados prestados a cada tipo de } \\
\text { dreno. }\end{array}$ \\
\hline PAPÉIS & $\begin{array}{l}\text { 1. Apoio } \\
\text { 2. Aprendizagem }\end{array}$ \\
\hline ATIVIDADES & $\begin{array}{l}\text { 1. Assistir a apresentação da aula sobre " Drenos". } \\
\text { 2. Assistir aos vídeos cujos links estão na aula } \\
\text { 3. Responder ao Quiz e mandar as respostas por e-mail } \\
\text { 4. Avaliar esta aula através de um depoimento que deverá ser postado em nosso } \\
\text { fórum onde todos os depoimentos serão compartilhados }\end{array}$ \\
\hline CARGA HORÁRIA & 04hs \\
\hline FERRAMENTAS & $\begin{array}{l}\text { Apresentação } \\
\text { Vídeos } \\
\text { Quizz } \\
\text { Fórum virtual } \\
\text { Avaliação }\end{array}$ \\
\hline CONTEÚDO & $\begin{array}{l}\text { Plano de aula } \\
\text { Rota de aprendizagem em Powerpoint } \\
\text { Slides da aula em Powerpoint } \\
\text { Vídeos no Youtube } \\
\text { Quizz } \\
\text { Fórum aberto para avaliação da aula } \\
\text { Referências bibliográficas }\end{array}$ \\
\hline AVALIAÇÃO & $\begin{array}{l}\text { Critérios de avaliação da tarefa expostos } \\
\text { Avaliação da tarefa } \\
\text { Autoavaliação } \\
\text { Avaliação da aula }\end{array}$ \\
\hline
\end{tabular}




\section{MATRIZ AULA 12}

\begin{tabular}{|c|c|}
\hline UNIDADE & Introdução à Oncologia \\
\hline OBJETIVOS & $\begin{array}{l}\text { 1. Entender a epidemiologia da doença; } \\
\text { 2. Conceitos básicos; } \\
\text { 3. Saber classificar os estadiamentos da doença; } \\
\text { 4. Conhecer as necessidades individuas de um paciente oncológico junto com a } \\
\text { equipe de saúde. } \\
\text { 5. Entender o ensino da Oncologia na enfermagem. }\end{array}$ \\
\hline PAPÉIS & $\begin{array}{l}\text { 1. Apoio } \\
\text { 2. Aprendizagem }\end{array}$ \\
\hline ATIVIDADES & $\begin{array}{l}\text { 1.Assistir a apresentação da aula sobre "Introdução a Oncologia” } \\
\text { 2. Acessar site } \\
\text { http://mortalidade.inca.gov.br/Mortalidade/prepararModelo05.action>, selecione } \\
\text { os dados ( Topografia :Todas as neoplasias, ano inicial: 1979, ano final: 1982, tipo de } \\
\text { taxa: bruta e sexo: fica por sua escolha!!!!). Observe o mapa e os dados } \\
\text { apresentados. Na sequência altere o ano inicial para : } 2008 \text { e o ano final para 2010, } \\
\text { observe o mapa e os dados. } \\
\text { 3.Entrar no fórum " O câncer no Brasil”" poste sua contribuição interagindo com seus } \\
\text { colegas; } \\
\text { 4. Ler os textos: "ENSINO DE ONCOLOGIA NA FORMAÇÃO DO ENFERMEIRO" e } \\
\text { "ASSISTÊNCIA HUMANIZADAAO CLIENTE ONCOLÓGICO: reflexões junto à equipe; } \\
\text { 5. Assistir ao vídeo "Paciente Oncológico e a Equipe de Saúde" } \\
\text { 6. Ler e postar a tarefa, em dupla, a ser realizada sobre o vídeo e os textos. } \\
\text { 7. Avaliar a aula no tópico "Avaliar essa aula" }\end{array}$ \\
\hline CARGA HORÁRIA & 04hs \\
\hline FERRAMENTAS & $\begin{array}{l}\text { Apresentação } \\
\text { Pesquisa online } \\
\text { Fórum virtual } \\
\text { Artigo científico } \\
\text { Vídeo } \\
\text { Tarefa } \\
\text { Avaliação }\end{array}$ \\
\hline CONTEÚDO & $\begin{array}{l}\text { Rota de aprendizagem em Powerpoint } \\
\text { Slides da aula em Powerpoint } \\
\text { Pesquisa online } \\
\text { Fórum virtual } \\
\text { Artigo em PDF } \\
\text { Vídeo no Youtube } \\
\text { Tarefa }\end{array}$ \\
\hline AVALIAÇÃO & $\begin{array}{l}\text { Critérios de avaliação da tarefa expostos } \\
\text { Avaliação da tarefa } \\
\text { Avaliação da aula }\end{array}$ \\
\hline
\end{tabular}




\section{MATRIZ AULA 13}

\begin{tabular}{|c|c|}
\hline UNIDADE & coagulação sanguínea \\
\hline OBJETIVOS & $\begin{array}{l}\text { Instrumentar o aluno quanto ao processo de coagulação do sangue e ao uso dos } \\
\text { medicamentos coagulantes e anticoagulantes } \\
\text { Objetivos específicos: } \\
\text { Compreenda o processo fisiológico da coagulação sanguínea incluindo os } \\
\text { componentes do sangue. } \\
\text { Compreenda porque, como e quando utilizar medicamentos coagulantes e } \\
\text { anticoagulantes } \\
\text { Esteja familiarizado com as indicações, contraindicações e efeitos colaterais de } \\
\text { coagulantes e anticoagulantes } \\
\text { Conheça e compreenda a importância dos cuidados de Enfermagem com } \\
\text { coagulantes e anticoagulantes } \\
\text { Saiba realizar cálculos de medicamentos coagulantes e anticoagulantes }\end{array}$ \\
\hline PAPÉIS & $\begin{array}{l}\text { 1. Apoio } \\
\text { 2. Aprendizagem }\end{array}$ \\
\hline ATIVIDADES & $\begin{array}{l}\text { 1.Assistir ao vídeo "Coagulação do sangue" que mostra como ocorre o processo de } \\
\text { coagulação sanguínea.http://www.youtube.com/watch?v=e4cQw70owYA } \\
\text { 2. Assistir a apresentação "Coagulantes e anticoagulantes" } \\
\text { 3. Acessar o fórum "E a coagulação?!"e participar do desafio proposto. } \\
\text { 4. Resolver o exercício proposto e postar no espaço "Cálculo de medicamentos" } \\
\text { 5. Postar sua avaliação sobre a aula em "minha opinião sobre a aula" }\end{array}$ \\
\hline CARGA HORÁRIA & 04hs \\
\hline FERRAMENTAS & $\begin{array}{l}\text { Vídeos } \\
\text { Apresentação } \\
\text { Fórum virtual } \\
\text { Tarefa } \\
\text { Avaliação }\end{array}$ \\
\hline CONTEÚDO & $\begin{array}{l}\text { Rota de aprendizagem em Powerpoint } \\
\text { Vídeo no Youtube } \\
\text { Slides da aula em Powerpoint } \\
\text { Fórum virtual } \\
\text { Tarefa "Cálculo de medicamento" } \\
\text { Fórum para contato com professor } \\
\text { Diário de avaliação da aula } \\
\text { Referências bibliográficas }\end{array}$ \\
\hline AVALIAÇÃO & $\begin{array}{l}\text { Critérios de avaliação da tarefa expostos } \\
\text { Avaliação da tarefa } \\
\text { Avaliação da aula }\end{array}$ \\
\hline
\end{tabular}




\section{MATRIZ AULA 14}

\begin{tabular}{|c|c|}
\hline UNIDADE & Demência \\
\hline OBJETIVOS & $\begin{array}{l}\text { 1. Compreender os conceitos acerca da demência } \\
\text { 2. Compreender e assimilar a assistência de enfermagem a ser oferecida } \\
\text { 3. Discutir os itens supra abordados }\end{array}$ \\
\hline PAPÉIS & $\begin{array}{l}\text { 1. Apoio } \\
\text { 2. Aprendizagem }\end{array}$ \\
\hline ATIVIDADES & $\begin{array}{l}\text { 1.Assistir a apresentação } \\
\text { 2.Assistir aos vídeos com casos práticos sobre apraxia, agnosia e afasia } \\
\text { 3.Abertura para discussão e levantamento de dúvidas } \\
\text { 4. Pesquisar artigos direcionados para discussão em um segundo momento }\end{array}$ \\
\hline CARGA HORÁRIA & 04hs \\
\hline FERRAMENTAS & $\begin{array}{l}\text { Apresentação } \\
\text { Vídeos } \\
\text { Pesquisa online } \\
\text { Avaliação }\end{array}$ \\
\hline CONTEÚDO & $\begin{array}{l}\text { Rota de aprendizagem em Powerpoint } \\
\text { Vídeos no Youtube } \\
\text { Slides da aula em Powerpoint }\end{array}$ \\
\hline AVALIAÇÃO & $\begin{array}{l}\text { Autoavaliação } \\
\text { Avaliação da aula }\end{array}$ \\
\hline
\end{tabular}

Obs. Nesta aula o aluno não esclareceu a forma como a discussão (item 3 atividades) seria realizada em ambiente virtual e também não orientou quanto à pesquisa de artigos (item 4). 


\section{MATRIZ AULA 15}

\begin{tabular}{|c|c|}
\hline UNIDADE & Introdução a Saúde Coletiva \\
\hline OBJETIVOS & $\begin{array}{l}\text { 1. Falar sobre o contexto e a prática que abrangem a Saúde Coletiva } \\
\text { Objetivos específicos: } \\
\text { Descrever sobre o surgimento da Saúde Coletiva. } \\
\text { Identificar situações no cotidiano de suas atividades como profissional onde se } \\
\text { aplica o contexto apresentado. } \\
\text { Realizar todas as atividades propostas do ambiente virtual. }\end{array}$ \\
\hline PAPÉIS & $\begin{array}{l}\text { 1. Apoio } \\
\text { 2. Aprendizagem }\end{array}$ \\
\hline ATIVIDADES & $\begin{array}{l}\text { 1. Assistir os vídeos Saude Coletiva e Definição de Saúde Coletiva } \\
\text { 2. Assistir a apresentação Introdução a Saúde Coletiva } \\
\text { 3. Acessar o fórum e postar a atividade contribuindo com os outros colegas } \\
\text { 4. Ler e desenvolver o exercício S.C. } \\
\text { 5. Postar a tarefa, em dupla. } \\
\text { 6. No final da atividade, dê a sua opinião sobre essa nova experiência no ambiente - } \\
\text { Dialogo }\end{array}$ \\
\hline CARGA HORÁRIA & 04hs \\
\hline FERRAMENTAS & $\begin{array}{l}\text { Vídeos } \\
\text { Apresentação } \\
\text { Fórum virtual } \\
\text { Tarefa } \\
\text { Avaliação }\end{array}$ \\
\hline CONTEÚDO & $\begin{array}{l}\text { Rota de aprendizagem em Powerpoint } \\
\text { Vídeo no Youtube } \\
\text { Slides da aula em Powerpoint } \\
\text { Artigo em PDF } \\
\text { Tarefa de questionário } \\
\text { Fórum privado para autoavaliação } \\
\text { Diário de avaliação da aula } \\
\text { Fórum para contato com professor } \\
\text { Referências bibliográficas }\end{array}$ \\
\hline AVALIAÇÃO & $\begin{array}{l}\text { Critérios de avaliação da tarefa expostos } \\
\text { Avaliação da tarefa } \\
\text { Autoavaliação } \\
\text { Avaliação da aula }\end{array}$ \\
\hline
\end{tabular}




\section{MATRIZ AULA 16}

\begin{tabular}{|c|c|}
\hline UNIDADE & Transtornos de humor \\
\hline OBJETIVOS & $\begin{array}{l}\text { 1. Conceituar os transtornos de humor } \\
\text { 2. Diferenciar mania e depressão, apresentando seus sinais e sintomas } \\
\text { 3. Refletir sobre as necessidades de saúde dos indivíduos com transtornos de humor }\end{array}$ \\
\hline PAPÉIS & $\begin{array}{l}\text { 1. Apoio } \\
\text { 2. Aprendizagem }\end{array}$ \\
\hline ATIVIDADES & $\begin{array}{l}\text { 1.Assistir a apresentação da aula "Transtornos de humor". } \\
\text { 2.Assistir os vídeos. } \\
\text { 3. Ler o texto que expõe um depoimento de um indivíduo com transtorno de humor. } \\
\text { 4. Participar do fórum de discussão. } \\
\text { 5. Fazer a atividade "O caso de Mariana". } \\
\text { 6. Fazer a avaliação da aula }\end{array}$ \\
\hline CARGA HORÁRIA & $04 \mathrm{hs}$ \\
\hline FERRAMENTAS & $\begin{array}{l}\text { Apresentação } \\
\text { Vídeo } \\
\text { Texto online } \\
\text { Fórum virtual } \\
\text { Tarefa } \\
\text { Avaliação }\end{array}$ \\
\hline CONTEÚDO & $\begin{array}{l}\text { Apresentação da aula em PDF } \\
\text { Rota de aprendizagem em PDF } \\
\text { Slides da aula em PowerPoint } \\
\text { Vídeo no Youtube } \\
\text { Texto online } \\
\text { Fórum virtual } \\
\text { Estudo de caso } \\
\text { Tarefa }\end{array}$ \\
\hline AVALIAÇÃO & $\begin{array}{l}\text { Critérios de avaliação da tarefa expostos } \\
\text { Avaliação da tarefa } \\
\text { Avaliação da aula }\end{array}$ \\
\hline
\end{tabular}




\section{MATRIZ AULA 17}

\begin{tabular}{|c|c|}
\hline UNIDADE & $\begin{array}{c}\text { Epidemiologia, Vigilância Epidemiológica e Doenças de } \\
\text { Notificação Compulsória }\end{array}$ \\
\hline OBJETIVOS & $\begin{array}{l}\text { 1. Conhecer o conceito de epidemiologia; } \\
\text { 2. Compreender a aplicação da epidemiologia no controle dos problemas de } \\
\text { saúde; } \\
\text { 3. Compreender a importância da Vigilância Epidemiológica e da Notificação } \\
\text { Compulsória na prevenção e controle das doenças }\end{array}$ \\
\hline PAPÉIS & $\begin{array}{l}\text { 1. Apoio } \\
\text { 2. Aprendizagem }\end{array}$ \\
\hline ATIVIDADES & $\begin{array}{l}\text { 1.Ler os seguintes textos: Epidemiologia- Noções Básicas e Atuação da Equipe de } \\
\text { Enfermagem na VE. } \\
\text { 2. Assista a apresentação da aula } \\
\text { 3.Assista os } 4 \text { vídeos: O caso de João, O retorno de João, O que os profissionais de } \\
\text { saúde devem saber e O caso de MS. } \\
\text { 4. Acesse o fórum "Epidemiologia e tuberculose" e poste sua contribuição. } \\
\text { 5. Acesse a atividade “Linha do tempo" e complete as cruzadas } \\
\text { 6. Leia a história “O desafio da UBS XXXI de Outubro". } \\
\text { 7. Responda e poste a tarefa relativa ao desafio da UBS XXXI de outubro. Você vai } \\
\text { precisar trabalhar em dupla nesta tarefa. } \\
\text { 8. Acesse o fórum de dúvidas se precisar de ajuda. } \\
\text { 9. Acesse a ferramenta "Avaliando esta experiência” e relate sua percepção sobre a } \\
\text { aula. }\end{array}$ \\
\hline CARGA HORÁRIA & 04hs \\
\hline FERRAMENTAS & $\begin{array}{l}\text { Artigo científico } \\
\text { Apresentação } \\
\text { Vídeo } \\
\text { Fórum virtual } \\
\text { Palavras cruzadas } \\
\text { Estudo de caso } \\
\text { Tarefa } \\
\text { Avaliação } \\
\text { Glossário } \\
\text { Bibliografia } \\
\text { Planilha de atividades }\end{array}$ \\
\hline CONTEÚDO & $\begin{array}{l}\text { Rota de aprendizagem em PPT } \\
\text { Artigo científico } \\
\text { Vídeo animado de autoria propria } \\
\text { Fórum virtual } \\
\text { Atividade palavras cruzadas } \\
\text { Estudo de caso } \\
\text { Tarefa } \\
\text { Fórum dúvidas } \\
\text { Avaliação da aula } \\
\text { Glossário } \\
\text { Bibliografia de referencia } \\
\text { Planilha de atividades }\end{array}$ \\
\hline AVALIAÇÃO & $\begin{array}{l}\text { Critérios de avaliação da tarefa expostos } \\
\text { Avaliação da tarefa } \\
\text { Avaliação da aula }\end{array}$ \\
\hline
\end{tabular}




\section{MATRIZ AULA 18}

\begin{tabular}{|c|c|}
\hline UNIDADE & Soroterapia \\
\hline OBJETIVOS & $\begin{array}{l}\text { 1. Conhecer o conceito de soroterapia ; } \\
\text { 2. Conceituar tipos de soluções utilizadas; } \\
\text { 3. Identificar rótulos de soros; } \\
\text { 4. Elencar quais são os materiais utilizados em soroterapia; } \\
\text { 5. Discorrer sobre os cuidados de enfermagem acerca da soroterapia; } \\
\text { 6. Observar e identificar intercorrências neste tipo de tratamento }\end{array}$ \\
\hline PAPÉIS & $\begin{array}{l}\text { 1. Apoio } \\
\text { 2. Aprendizagem }\end{array}$ \\
\hline ATIVIDADES & $\begin{array}{l}\text { 1.Acesse o fórum Conhecimentos Prévios e compartilhe com os colegas e comigo as } \\
\text { experiências que você já vivenciou com soroterapia } \\
\text { 2. Faça o exercício das frases embaralhadas; } \\
\text { 3.Assista a apresentação da aula sobre "Soroterapia". } \\
\text { 4.Assista o vídeo sobre a demonstração da técnica; } \\
\text { 5.Retorne ao exercício das frases embaralhadas e se julgar necessário modifique a } \\
\text { ordem; } \\
\text { 6.Participe do nosso Quizz Show; } \\
\text { 7.Poste as respostas Quizz Show no fórum desta atividade } \\
\text { 8.E por fim vá até a ferramenta "Avaliando essa experiência" e relate sua percepção } \\
\text { dessa aula. }\end{array}$ \\
\hline CARGA HORÁRIA & 04hs \\
\hline FERRAMENTAS & $\begin{array}{l}\text { Apresentação } \\
\text { Fórum virtual } \\
\text { Atividade - palavras embaralhadas } \\
\text { Vídeo } \\
\text { Quizz } \\
\text { Tarefa } \\
\text { Avaliação }\end{array}$ \\
\hline CONTEÚDO & $\begin{array}{l}\text { Rota de aprendizagem em PowerPoint } \\
\text { Fórum virtual } \\
\text { Atividade - palavras embaralhadas } \\
\text { Slides da aula em PowerPoint } \\
\text { Vídeo no Youtube } \\
\text { Quizz } \\
\text { Tarefa } \\
\text { Avaliação da aula }\end{array}$ \\
\hline AVALIAÇÃO & $\begin{array}{l}\text { Critérios de avaliação da tarefa expostos } \\
\text { Avaliação da tarefa } \\
\text { Avaliação da aula }\end{array}$ \\
\hline
\end{tabular}




\section{MATRIZ AULA 19}

\begin{tabular}{|c|c|}
\hline UNIDADE & Doenças ginecológicas \\
\hline OBJETIVOS & $\begin{array}{l}\text { 1. Conhecer algumas das doenças ginecológicas } \\
\text { 2. Compreender a fisiopatologia das doenças ginecológicas } \\
\text { 3. Identificar o desenvolvimento da doença } \\
\text { 4. Relacionar os cuidados de enfermagem com as doenças ginecológicas }\end{array}$ \\
\hline PAPÉIS & $\begin{array}{l}\text { 1. Apoio } \\
\text { 2. Aprendizagem }\end{array}$ \\
\hline ATIVIDADES & $\begin{array}{l}\text { 1.Assistir a aula Doenças Ginecológicas } \\
\text { 2. Assistir ao vídeo anatomia feminina } \\
\text { 3. Assistir ao vídeo câncer de colo de útero } \\
\text { 4. Assistir ao vídeo Câncer de Mama } \\
\text { 5. Realizar e enviar a tarefa } \\
\text { 6. Ler a fundamentação teórica } \\
\text { 7. Assistir ao vídeo - Nós fazemos a diferença } \\
\text { 8. Acessar o Fórum de Dúvidas }\end{array}$ \\
\hline CARGA HORÁRIA & 04hs \\
\hline FERRAMENTAS & $\begin{array}{l}\text { Apresentação } \\
\text { Vídeo } \\
\text { Tarefa } \\
\text { Palavras cruzadas }\end{array}$ \\
\hline CONTEÚDO & $\begin{array}{l}\text { Aula Doenças Ginecológicas Powerpoint } \\
\text { Vídeo Anatomia Feminina } \\
\text { Vídeo câncer de colo de útero } \\
\text { Vídeo Câncer de Mama } \\
\text { Atividade palavras cruzadas } \\
\text { Envio da Tarefa } \\
\text { Fundamentação teórica no Word } \\
\text { Vídeo - Nós fazemos a diferença } \\
\text { Fórum de Dúvidas }\end{array}$ \\
\hline
\end{tabular}




\section{MATRIZ AULA 20}

\begin{tabular}{|c|c|}
\hline UNIDADE & Doenças Infecto-contagiosas \\
\hline OBJETIVOS & $\begin{array}{l}\text { 1. Identificar uma doença infecto-contagiosa; } \\
\text { 2. Compreender as formas de transmissão das doenças; } \\
\text { 3. Identificar os sinais e sintomas das doenças; } \\
\text { 4. Conhecer os diferentes tratamentos das doenças; } \\
\text { 5. Conhecer as profilaxias das doenças. }\end{array}$ \\
\hline PAPÉIS & $\begin{array}{l}\text { 1. Apoio } \\
\text { 2. Aprendizagem }\end{array}$ \\
\hline ATIVIDADES & $\begin{array}{l}\text { 1.Assista ao vídeo "lavar as mãos"; } \\
\text { 2. Acesse o fórum "lavar as mãos" poste a sua contribuição , veja a colaboração de } \\
\text { seus colegas e interaja com eles; } \\
\text { 3. Assista a apresentação da aula " Doenças Infecto-contagiosas"; } \\
\text { 4. Assista ao vídeo "Influenza A" } \\
\text { 5. Leia e poste a tarefa "Agora é a sua vez"; } \\
\text { 6. Se tiver alguma duvida, temos o nosso fórum de "duvidas"; } \\
\text { 7. Ao final, avalie esta aula em "Avaliando a aula". }\end{array}$ \\
\hline CARGA HORÁRIA & 04hs \\
\hline FERRAMENTAS & $\begin{array}{l}\text { Vídeo } \\
\text { Fórum virtual } \\
\text { Apresentação } \\
\text { Tarefa } \\
\text { Avaliação }\end{array}$ \\
\hline CONTEÚDO & $\begin{array}{l}\text { Rota de aprendizagem em PPT } \\
\text { Vídeo - Lavar as mãos } \\
\text { Fórum virtual - Lavar as Mãos } \\
\text { Apresentação da aula em PPT - Doenças Infecto-contagiosas } \\
\text { Vídeo - "H1N1" } \\
\text { Tarefa - Agora é a sua vez } \\
\text { Envio da Tarefa } \\
\text { "Fórum de duvidas" } \\
\text { Avaliação da aula virtual } \\
\text { Bibliografia }\end{array}$ \\
\hline AVALIAÇÃO & $\begin{array}{l}\text { Critérios de avaliação da tarefa expostos } \\
\text { Avaliação da tarefa } \\
\text { Avaliação da aula }\end{array}$ \\
\hline
\end{tabular}




\section{MATRIZ AULA 21}

\begin{tabular}{|c|c|}
\hline UNIDADE & Cuidados imediatos ao RN \\
\hline OBJETIVOS & $\begin{array}{l}\text { 1. Definir e diferenciar os cuidados imediatos dos mediatos ao RN; } \\
\text { 2. Compreender a necessidade dos cuidados prestados; } \\
\text { 3. Garantir o conhecimento teórico que propicie a aplicação na prática. }\end{array}$ \\
\hline PAPÉIS & $\begin{array}{l}\text { 1. Apoio } \\
\text { 2. Aprendizagem }\end{array}$ \\
\hline ATIVIDADES & $\begin{array}{l}\text { 1.Assistir a apresentação da aula } \\
\text { 2.Assistir os vídeos } \\
\text { 3. Responder ao questionário } \\
\text { 4. Participar do fórum de discussão } \\
\text { 5. Participar da construção da bibliografia } \\
\text { 6. Fazer a avaliação da aula }\end{array}$ \\
\hline CARGA HORÁRIA & 04hs \\
\hline FERRAMENTAS & $\begin{array}{l}\text { Apresentação } \\
\text { Vídeo } \\
\text { Questionário } \\
\text { Fórum virtual } \\
\text { Bibliografia participativa } \\
\text { Avaliação }\end{array}$ \\
\hline CONTEÚDO & $\begin{array}{l}\text { Rota de Aprendizagem em PPT } \\
\text { Apresentação teórica em PPT } \\
\text { Vídeo Exame físico RN - Youtube } \\
\text { Vídeo Hora do Banho - Youtube } \\
\text { Questionário “Jogo Rápido" } \\
\text { Fórum: Os Cuidados com o RN } \\
\text { Bibliografia Participativa - Base de dados } \\
\text { Avaliação da Aula }\end{array}$ \\
\hline AVALIAÇÃO & $\begin{array}{l}\text { Critérios de avaliação da tarefa expostos } \\
\text { Avaliação da tarefa } \\
\text { Avaliação da aula }\end{array}$ \\
\hline
\end{tabular}




\section{MATRIZ AULA 22}

\begin{tabular}{|c|c|}
\hline UNIDADE & Estratégia Saúde da família e Programas de Saúde \\
\hline OBJETIVOS & $\begin{array}{l}\text { 1. Compreenda o conceito de Estratégia Saúde da Família e programas de saúde } \\
\text { da criança, adolescente, mulher e idoso. } \\
\text { 2. Conheça a atuação dos auxiliares de enfermagem na Estratégia Saúde da } \\
\text { Família. } \\
\text { 3. Conheça e refletir sobre os programas de saúde da criança, adolescente, mulher } \\
\text { e idoso. }\end{array}$ \\
\hline PAPÉIS & $\begin{array}{l}\text { 1. Apoio } \\
\text { 2. Aprendizagem }\end{array}$ \\
\hline ATIVIDADES & $\begin{array}{l}\text { 1.Postar atividade no fórum "Estratégia Saúde da Família e Programas de Saúde" } \\
\text { 2. Assista a apresentação "Estratégia Saúde Da Família". } \\
\text { 3. Assista ao vídeo correspondente } \\
\text { 4. Assista a apresentação "Programa De Assistência Integral À Saúde Da Criança } \\
\text { (PAISC)". } \\
\text { 5.Assista ao vídeo correspondente } \\
\text { 6. Assista a apresentação "Programa De Saúde Do Adolescente (PROSAD)". } \\
\text { 7. Assista ao vídeo correspondente } \\
\text { 8. Assista a apresentação "Programa De Assistência Integral À Saúde Da Mulher } \\
\text { (PAISM)". } \\
\text { 9. Assista ao vídeo correspondente } \\
\text { 10. Assista a apresentação "Política Nacional De Saúde Do Idoso (PSNI)". } \\
\text { 11. Assista ao vídeo correspondente } \\
\text { 12. Postar a atividade de aprofundamento } \\
\text { 13. Relate sua percepção desta aula. }\end{array}$ \\
\hline CARGA HORÁRIA & 04hs \\
\hline FERRAMENTAS & $\begin{array}{l}\text { Fórum virtual } \\
\text { Apresentação } \\
\text { Vídeo } \\
\text { Tarefa } \\
\text { Avaliação }\end{array}$ \\
\hline CONTEÚDO & $\begin{array}{l}\text { Rota de aprendizagem em Word } \\
\text { Fórum virtual } \\
\text { Apresentação da aula ESF } \\
\text { Video institucional saúde da família } \\
\text { Apresentação PAISC } \\
\text { Vídeo saúde da criança } \\
\text { Apresentação PROSAD } \\
\text { Vídeo saúde do adolescente } \\
\text { Apresentação PAISM } \\
\text { Vídeo saúde da mulher } \\
\text { Apresentação PSNI } \\
\text { Vídeo saúde do idoso } \\
\text { Atividade de aprofundamento Tarefa } \\
\text { Avaliando a aula }\end{array}$ \\
\hline AVALIAÇÃO & $\begin{array}{l}\text { Critérios de avaliação da tarefa expostos } \\
\text { Avaliação da tarefa } \\
\text { Avaliação da aula }\end{array}$ \\
\hline
\end{tabular}




\section{MATRIZ AULA 23}

\begin{tabular}{|c|c|}
\hline UNIDADE & Métodos contraceptivos \\
\hline OBJETIVOS & $\begin{array}{l}\text { 1. Compreender e descrever o ciclo menstrual, relacionando os dias do ciclo com as } \\
\text { alterações na parede uterina e no desenvolvimento/liberação do óvulo. } \\
\text { 2. Conhecer todas as formas de métodos contraceptivos, expondo seus mecanismos } \\
\text { de ação e as alterações que provocam no organismo feminino. } \\
\text { 3. Interagir com demais colegas de turma em uma plataforma de fórum }\end{array}$ \\
\hline PAPÉIS & $\begin{array}{l}\text { 1. Apoio } \\
\text { 2. Aprendizagem }\end{array}$ \\
\hline ATIVIDADES & $\begin{array}{l}\text { 1.Assistir aos vídeos sobre o ciclo menstrual } \\
\text { 2. Assistir a apresentação da aula "Ciclo Menstrual" } \\
\text { 3.Postar a resposta da atividade solicitada } \\
\text { 4. Assistir a apresentação "Aula métodos contraceptivos" } \\
\text { 5. Assistir aos vídeos propostos. } \\
\text { 6.Postar no fórum "Métodos contraceptivos" } \\
\text { 7.Avalie essa aula }\end{array}$ \\
\hline CARGA HORÁRIA & $04 \mathrm{hs}$ \\
\hline FERRAMENTAS & $\begin{array}{l}\text { Apresentação } \\
\text { Vídeos } \\
\text { Tarefa } \\
\text { Fórum virtual } \\
\text { Avaliação }\end{array}$ \\
\hline CONTEÚDO & $\begin{array}{l}\text { Rota de aprendizagem em Powerpoint } \\
\text { Vídeo - Ciclo menstrual } 1 \\
\text { Vídeo - Ciclo menstrual } 2 \\
\text { Vídeo - Ciclo menstrual } 3 \\
\text { Apresentação da aula ciclo menstrual em Powerpoint } \\
\text { Tarefa } \\
\text { Apresentação da aula Métodos Contraceptivos em Powerpoint } \\
\text { Vídeo Métodos anticoncepcionais } \\
\text { Vídeo Métodos anticoncepcionais - } 2 \\
\text { Atividade Fórum }\end{array}$ \\
\hline AVALIAÇÃO & $\begin{array}{l}\text { Critérios de avaliação da tarefa expostos } \\
\text { Avaliação da tarefa } \\
\text { Avaliação da aula }\end{array}$ \\
\hline
\end{tabular}




\section{MATRIZ AULA 24}

UNIDADE

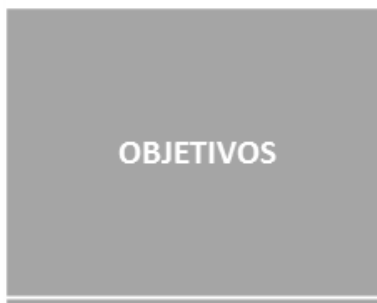

PAPÉIS

CARGA HORÁRIA
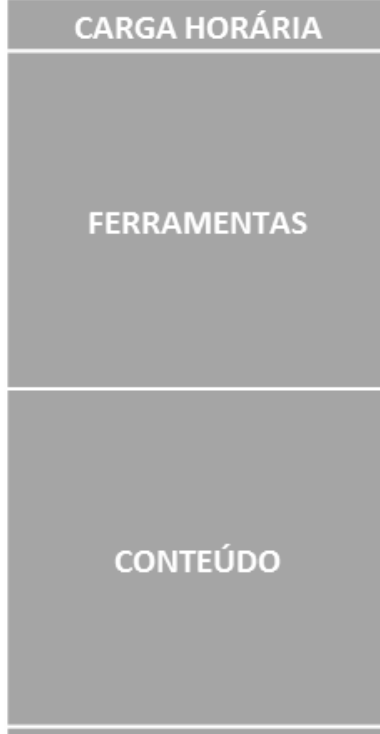

AVALIAÇÃo

\section{Assistência ao Pré-Natal, modificações gravídicas e o parto}

1. Compreensão das modificações gravídicas e o período pré-natal como uma oportunidade de apropriar-se dos cuidados com a mãe e o bebê.

2. Reconhecer os cuidados de enfermagem durante o pré-natal.

3. Distinguir tipos de parto e os cuidados de enfermagem durante o trabalho de parto.

4. Reflexão a cerca do parto normal e cesariana diante da atual situação da saúde no Brasil.

1. Apoio

2. Aprendizagem

1.Aula "Assistência ao pré-natal, modificações e parto".

2. Vídeo "Parto Normal e Cesárea"

3. Leitura de Artigo: parto normal X parto cesárea

4.Discussão coletiva no fórum

5. Realizar a tarefa e estudo de caso

6. Participação do fórum: Parto natural x parto cesárea.

7. Fórum de Participação coletiva e dúvidas

04hs

Apresentação

Vídeo

Artigo científico

Fórum virtual

Tarefa

Estudo de caso

Avaliação

Rota de aprendizagem no Word

Apresentação da aula em PPT

Vídeo no Youtube "Parto Normal e Cesárea"

Artigo: parto normal X parto cesárea

Fórum "Parto natural x Parto cesárea"

Tarefa

Fórum de Participação Coletiva e Dúvidas

Critérios de avaliação da tarefa expostos

Avaliação da tarefa 


\section{MATRIZ AULA 25}

\begin{tabular}{|c|c|}
\hline UNIDADE & Monitorização Glicêmica \\
\hline OBJETIVOS & $\begin{array}{l}\text { 1. Reconhecer o material para realização do procedimento } \\
\text { 2. Abordar adequadamente o paciente para execução do procedimento } \\
\text { 3. Aprender os cuidados de enfermagem envolvidos na realização da } \\
\text { monitorização glicêmica } \\
\text { 4. Anotar os valores glicêmicos na planilha de controle } \\
\text { 5. Conhecer os principais aparelhos (glicosímetros) de uso hospitalar e doméstico }\end{array}$ \\
\hline PAPÉIS & $\begin{array}{l}\text { 1. Apoio } \\
\text { 2. Aprendizagem }\end{array}$ \\
\hline ATIVIDADES & $\begin{array}{l}\text { 1.Assista apresentação da Aula Introdutória } \\
\text { 2.Assista o vídeo sobre a Técnica de Monitorização Glicêmica } \\
\text { 3.Leia o texto sobre Monitorização Glicêmica } \\
\text { 4.Participe do Fórum "Cuidados necessários" - Poste sua contribuição e relacione } \\
\text { com as dos colegas } \\
\text { 5.Coletivamente façam uma pesquisa sobre os principais aparelhos que são } \\
\text { utilizados em ambiente doméstico e hospitalar, citando quais as possíveis vantagens } \\
\text { e desvantagens de cada um deles. }\end{array}$ \\
\hline CARGA HORÁRIA & $04 \mathrm{hs}$ \\
\hline FERRAMENTAS & $\begin{array}{l}\text { Apresentação } \\
\text { Vídeo } \\
\text { Artigo Científico } \\
\text { Fórum virtual } \\
\text { Pesquisa Online } \\
\text { Avaliação da aula }\end{array}$ \\
\hline CONTEÚDO & $\begin{array}{l}\text { Rota de Aprendizagem em PPT } \\
\text { Apresentação da aula PPT } \\
\text { Vídeo sobre a Técnica de Monitorização Glicêmica } \\
\text { Artigo Científico } \\
\text { Fórum “Cuidados necessários” } \\
\text { Pesquisa coletiva }\end{array}$ \\
\hline AVALIAÇÃO & Avaliação da aula \\
\hline
\end{tabular}




\section{MATRIZ AULA 26}

\begin{tabular}{|c|c|}
\hline UNIDADE & Ciclo menstrual, Gravidez e Desenvolvimento fetal \\
\hline OBJETIVOS & $\begin{array}{l}\text { 1. Definir as fases do ciclo menstrual, da gravidez e desenvolvimento fetal } \\
\text { 2. Compreender o processo de humanização no período gravídico }\end{array}$ \\
\hline PAPÉIS & $\begin{array}{l}\text { 1. Apoio } \\
\text { 2. Aprendizagem }\end{array}$ \\
\hline ATIVIDADES & $\begin{array}{l}\text { 1. Leia os capítulos do Manual Técnico Pré-natal e Puerpério } \\
\text { 2. Assista a apresentação da aula } \\
\text { 3. Assista o vídeo: Gravidez - Fecundação ao Nascimento } \\
\text { 4. Acesse o fórum e poste sua contribuição. } \\
\text { 5. Leia a Proposta de Atividade, realize as tarefas e envie-as. } \\
\text { 6. Preencha o documento de Avaliação da Aula e envie-o. }\end{array}$ \\
\hline CARGA HORÁRIA & $04 \mathrm{hs}$ \\
\hline FERRAMENTAS & $\begin{array}{l}\text { Texto online } \\
\text { Apresentação } \\
\text { Vídeo } \\
\text { Fórum virtual } \\
\text { Tarefa } \\
\text { Avaliação }\end{array}$ \\
\hline CONTEÚDO & $\begin{array}{l}\text { Rota de aprendizagem Powerpoint } \\
\text { Texto Pré-Natal e Puerpério em PDF } \\
\text { Apresentação da aula em PPT } \\
\text { Vídeo no youtube } \\
\text { Fórum virtual } \\
\text { Tarefa } \\
\text { Bibliografia de apoio }\end{array}$ \\
\hline AVALIAÇÃO & $\begin{array}{l}\text { Critérios de avaliação da tarefa expostos } \\
\text { Avaliação da tarefa } \\
\text { Avaliação da aula }\end{array}$ \\
\hline
\end{tabular}




\section{MATRIZ AULA 27}

\begin{tabular}{|c|c|}
\hline UNIDADE & Tabaco e outras Drogas \\
\hline OBJETIVOS & $\begin{array}{l}\text { 1. Compreender a fisiopatologia da substância psicoativa. } \\
\text { 2. Diferenciar os conceito de uso, abuso e dependência de substâncias psicoativas. } \\
\text { 3. Identificar sintomas de abstinência nos usuários. }\end{array}$ \\
\hline PAPÉIS & $\begin{array}{l}\text { 1. Apoio } \\
\text { 2. Aprendizagem }\end{array}$ \\
\hline ATIVIDADES & $\begin{array}{l}\text { 1. Leia a aula sobre álcool, tabaco e outras drogas. } \\
\text { 2. Assista o vídeo. } \\
\text { 3. Vá ao Fórum e poste a sua contribuição. } \\
\text { 4. Responda e poste a tarefa. } \\
\text { 5. Relate sua percepção dessa aula. }\end{array}$ \\
\hline CARGA HORÁRIA & 04hs \\
\hline FERRAMENTAS & $\begin{array}{l}\text { Apresentação } \\
\text { Vídeo } \\
\text { Fórum virtual } \\
\text { Tarefa } \\
\text { Avaliação }\end{array}$ \\
\hline CONTEÚDO & $\begin{array}{l}\text { Rota de aprendizagem em PPT } \\
\text { Apresentação da Aula em PPT } \\
\text { Vídeo no Youtube } \\
\text { Fórum “ Johnny pode ser considerado um dependente?" } \\
\text { Tarefa "Construindo um raciocínio lógico" }\end{array}$ \\
\hline AVALIAÇÃO & $\begin{array}{l}\text { Critérios de avaliação da tarefa expostos } \\
\text { Avaliação da tarefa } \\
\text { Avaliação da aula }\end{array}$ \\
\hline
\end{tabular}




\section{MATRIZ AULA 28}

\begin{tabular}{|c|c|}
\hline UNIDADE & Feridas \\
\hline OBJETIVOS & O licenciando não expôs os objetivos da aula \\
\hline PAPÉIS & $\begin{array}{l}\text { 1. Apoio } \\
\text { 2. Aprendizagem }\end{array}$ \\
\hline ATIVIDADES & $\begin{array}{l}\text { 1. Ler o texto } \\
\text { 2. Assistir a apresentação da aula } \\
\text { 3. Assistir os vídeos } \\
\text { 4. Participar do fórum de discussão } \\
\text { 5. Realizar e enviar a tarefa } \\
\text { 6. Fazer a avaliação da aula }\end{array}$ \\
\hline CARGA HORÁRIA & 04hs \\
\hline FERRAMENTAS & $\begin{array}{l}\text { Texto online } \\
\text { Apresentação } \\
\text { Vídeo } \\
\text { Fórum virtual } \\
\text { Tarefa } \\
\text { Avaliação }\end{array}$ \\
\hline CONTEÚDO & $\begin{array}{l}\text { Texto em PDF } \\
\text { Apresentação da aula Feridas em PDF } \\
\text { Vídeo Lesões da Pele } \\
\text { Vídeo Hidrocolóide } \\
\text { Vídeo Curativos e Técnicas } \\
\text { Fórum Virtual } \\
\text { Tarefa }\end{array}$ \\
\hline AVALIAÇÃO & $\begin{array}{l}\text { Avaliação da tarefa } \\
\text { Avaliação da aula }\end{array}$ \\
\hline
\end{tabular}




\section{MATRIZ AULA 29}

\begin{tabular}{|c|c|}
\hline UNIDADE & Aspiração traqueal \\
\hline OBJETIVOS & $\begin{array}{l}\text { 1. Identificar as disfunções do sistema respiratório, realizar as técnicas de aspiração } \\
\text { traqueal, além de correlacionar o diagnóstico com a técnica aprendida. }\end{array}$ \\
\hline PAPÉIS & $\begin{array}{l}\text { 1. Apoio } \\
\text { 2. Aprendizagem }\end{array}$ \\
\hline ATIVIDADES & $\begin{array}{l}\text { 1. Assistir a apresentação da aula } \\
\text { 2. Ler os artigos científicos } \\
\text { 3. Participar do fórum de discussão }\end{array}$ \\
\hline CARGA HORÁRIA & 04hs \\
\hline FERRAMENTAS & $\begin{array}{l}\text { Apresentação } \\
\text { Artigo Científico } \\
\text { Fórum virtual }\end{array}$ \\
\hline CONTEÚDO & $\begin{array}{l}\text { Apresentação da aula em Powerpoint } \\
\text { Artigos científicos para leitura } \\
\text { Fórum }\end{array}$ \\
\hline AVALIAÇÃO & Avaliação do fórum \\
\hline
\end{tabular}




\section{MATRIZ AULA 30}

\begin{tabular}{|c|c|}
\hline UNIDADE & Diabetes Mellitus \\
\hline OBJETIVOS & $\begin{array}{l}\text { 1. Compreender a fisiopatologia do Diabetes Mellitus tipo } 1 \text { e Diabetes Mellitus } \\
\text { tipo } 2 \\
\text { 2. Reconhecer os sinais e sintomas de hipoglicemia e hiperglicemia } \\
\text { 3. Compreender e intervir nos casos de hipoglicemia e hiperglicemia } \\
\text { 4. Reconhecer o Diabetes Mellitus como uma doença que acarreta mudanças no } \\
\text { estilo de vida dos pacientes }\end{array}$ \\
\hline PAPÉIS & $\begin{array}{l}\text { 1. Apoio } \\
\text { 2. Aprendizagem }\end{array}$ \\
\hline ATIVIDADES & $\begin{array}{l}\text { 1. Participe do fórum virtual } \\
\text { 2. Assista a apresentação da aula } \\
\text { 3. Procure um artigo científico que relate sobre a experiência de pessoas que têm } \\
\text { diabetes. Vamos construir uma biblioteca coletiva sobre a experiência de } \\
\text { conviver com o diabetes } \\
\text { 4. Resuma a aula com as suas palavras e envie no espaço destinado para } \\
\text { "Postagem da avaliação" } \\
\text { 5. Avalie a experiência desta aula }\end{array}$ \\
\hline CARGA HORÁRIA & 04hs \\
\hline FERRAMENTAS & $\begin{array}{l}\text { Fórum virtual } \\
\text { Apresentação } \\
\text { Pesquisa online } \\
\text { Biblioteca virtual colaborativa } \\
\text { Tarefa } \\
\text { Avaliação }\end{array}$ \\
\hline CONTEÚDO & $\begin{array}{l}\text { Rota de Aprendizagem em Word } \\
\text { Fórum virtual } \\
\text { Apresentação da aula em PDF } \\
\text { Biblioteca colaborativa } \\
\text { Tarefa }\end{array}$ \\
\hline AVALIAÇÃO & $\begin{array}{l}\text { Avaliação da tarefa } \\
\text { Avaliação da aula }\end{array}$ \\
\hline
\end{tabular}




\section{MATRIZ AULA 31}

\begin{tabular}{|c|c|}
\hline UNIDADE & Diabetes Mellitus \\
\hline OBJETIVOS & $\begin{array}{l}\text { 1. Identificar os principais aspetos anatônico e fisiólogicas do sistema endocrino; } \\
\text { 2. Conhecer a fisiologia, os simais e sintomas da diabete; } \\
\text { 3. Diferenciar os tipos de Diabetes e as suas complicações; } \\
\text { 4. Analisar os cuidados de enfermagem; } \\
\text { 5. Participar das atividades da aula. }\end{array}$ \\
\hline PAPÉIS & $\begin{array}{l}\text { 1. Apoio } \\
\text { 2. Aprendizagem }\end{array}$ \\
\hline ATIVIDADES & $\begin{array}{l}\text { 1. Leia os artigos } \\
\text { 2.Assista os vídeos } \\
\text { 3.Assista a apresentação da aula } \\
\text { 4. Acesse ao fórum e responda os exercícios de raciocínio, poste a sua contribuição e } \\
\text { interaja com os seus colegas; } \\
\text { 5. Leia o Manual de Enfermagem } \\
\text { 6. Relate a sua experiência. }\end{array}$ \\
\hline CARGA HORÁRIA & 04hs \\
\hline FERRAMENTAS & $\begin{array}{l}\text { Artigo científico } \\
\text { Vídeo } \\
\text { Apresentação } \\
\text { Fórum virtual } \\
\text { Texto online } \\
\text { Tarefa } \\
\text { Avaliação }\end{array}$ \\
\hline CONTEÚDO & $\begin{array}{l}\text { Rota de Aprendizagem } \\
\text { Artigo - Diabetes Mellitus Diagnostico em PDF } \\
\text { Artigo - SAE em PDF } \\
\text { Vídeo no Youtube Diabetes tipo } 1 \\
\text { Vídeo no Youtube Diabetes Tipo } 2 \text { Arquivo } \\
\text { Apresentação da aula "Diabetes Mellitus e intervenção de enfermagem" } \\
\text { Fórum virtual } \\
\text { Manual de Enfermagem em PDF }\end{array}$ \\
\hline AVALIAÇÃO & Avaliação da aula \\
\hline
\end{tabular}




\section{MATRIZ AULA 32}

\begin{tabular}{|c|c|}
\hline UNIDADE & Insuficiência renal \\
\hline OBJETIVOS & $\begin{array}{l}\text { 1. Relembrar a anatomia e fisiologia do sistema urinário } \\
\text { 2. Discorrer sobre insuficiência renal aguda e insuficiência real crônica } \\
\text { 3. Construir o papel do técnico de enfermagem frente ao doente renal }\end{array}$ \\
\hline PAPÉIS & $\begin{array}{l}\text { 1. Apoio } \\
\text { 2. Aprendizagem }\end{array}$ \\
\hline ATIVIDADES & $\begin{array}{l}\text { 1.Leia os artigos } \\
\text { 2. Escreva um texto reflexivo sobre a importância da doença renal no Brasil } \\
\text { 3. Leia a apostila sobre o sistema urinário e responda as perguntas que estão no final } \\
\text { da apostila } \\
\text { 4.Assista o vídeo sobre insuficiência renal } \\
\text { 5.Pesquise sobre as causas, consequências e mecanismos patológicos dessa doença } \\
\text { 6.Em trio construa um vídeo, uma musica ou uma peça de teatro explicando essa } \\
\text { patologia }\end{array}$ \\
\hline CARGA HORÁRIA & 04hs \\
\hline FERRAMENTAS & $\begin{array}{l}\text { Artigo científico } \\
\text { Texto reflexivo } \\
\text { Apostila } \\
\text { Vídeo } \\
\text { Pesquisa online } \\
\text { Tarefa }\end{array}$ \\
\hline CONTEÚDO & $\begin{array}{l}\text { Rota de aprendizagem em PowerPoint } \\
\text { Artigo - “Dados Disponíveis Sobre a Doença Renal Crônica no Brasil” em PDF } \\
\text { Artigo - “Narrativa de uma cliente com insuficiência renal crônica: A historia oral } \\
\text { com estratégia de pesquisa” em Word } \\
\text { Tarefa texto reflexivo } \\
\text { Apostila em PDF } \\
\text { Vídeo no Youtube - Sistema Urinário }\end{array}$ \\
\hline AVALIAÇÃO & Avaliação da tarefa \\
\hline
\end{tabular}




\section{MATRIZ AULA 33}

\begin{tabular}{|c|c|}
\hline UNIDADE & Higienização das Mãos \\
\hline OBJETIVOS & $\begin{array}{l}\text { 1. Reconhecer a importância do tema abordado; } \\
\text { 2. Conhecer perspectiva histórica sobre a Lavagem das Mãos na saúde; } \\
\text { 3. Conhecer o processo de Higienização das Mãos; } \\
\text { 4. Conhecer os tipos e as técnicas de Higienização das Mãos; } \\
\text { 5. Ser capaz de realizar argumentações e reflexões sobre o tema; } \\
\text { 6. Discutir com os colegas sobre a frequência e técnica do tema na unidade } \\
\text { 7. Expressar suas percepções sobre a aula. }\end{array}$ \\
\hline PAPÉIS & $\begin{array}{l}\text { 1. Apoio } \\
\text { 2. Aprendizagem }\end{array}$ \\
\hline ATIVIDADES & $\begin{array}{l}\text { 1. Responda a seguinte questão: Porque é importante higienizar minhas mãos, } \\
\text { principalmente no hospital. } \\
\text { 2.Envie sua resposta no espaço “Porque Devo?" } \\
\text { 3. Assista aos vídeos } \\
\text { 4. Assista a apresentação da aula } \\
\text { 5. Leia o trecho determinado do Guia de higienização da Anvisa; } \\
\text { 6. Realize as duas atividades } \\
\text { 7. Converse com os amigos no fórum de discussão. } \\
\text { 8. Relate suas percepções com a avaliação da aula }\end{array}$ \\
\hline CARGA HORÁRIA & 04hs \\
\hline FERRAMENTAS & $\begin{array}{l}\text { Tarefa } \\
\text { Vídeo } \\
\text { Apresentação } \\
\text { Texto online } \\
\text { Fórum virtual } \\
\text { Avaliação }\end{array}$ \\
\hline CONTEÚDO & $\begin{array}{l}\text { Rota de aprendizagem } \\
\text { Fórum - “Porque Devo?” } \\
\text { Vídeo no Youtube - Reportagem: Importância de lavar as mãos } \\
\text { Vídeo no Youtube - Reportagem: Pesquisa alunos graduação } \\
\text { Vídeo no Youtube - Guia da Anvisa } \\
\text { Apresentação da aula em PowerPoint } \\
\text { Texto em PDF } \\
\text { Atividade } 1 \text { - Discussão sobre a adesão } \\
\text { Atividade } 2 \text { - Carta } \\
\text { Fórum Virtual } \\
\text { Fórum de dúvidas } \\
\text { Biblioteca Virtual }\end{array}$ \\
\hline AVALIAÇÃo & $\begin{array}{l}\text { Critérios de avaliação da tarefa expostos } \\
\text { Avaliação da tarefa } \\
\text { Avaliação da aula }\end{array}$ \\
\hline
\end{tabular}


A apresentação dos dados desta pesquisa seguirá a ordem dos itens da matriz de design instrucional: Objetivos, papéis, atividades, carga horária, ferramentas, conteúdos e avaliação.

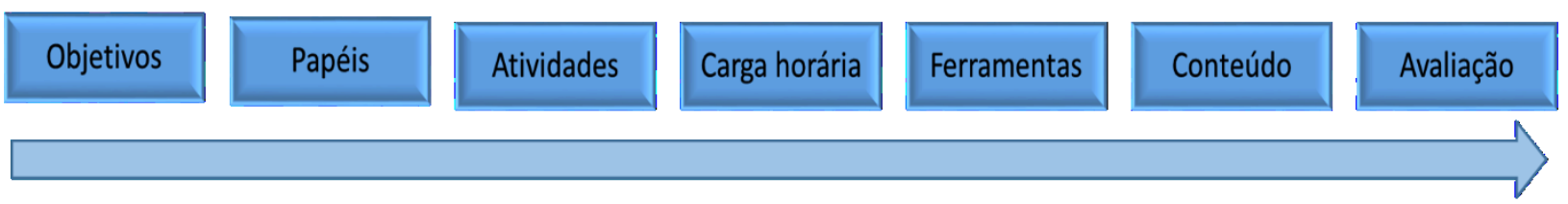

Figura 5: Representação gráfica da ordem de apresentação dos dados segundo a matriz de design instrucional.

(Autoria: Vanessa L.M. Afonso, 2014).

\subsection{OBJETIVOS}

Entendemos por objetivos educacionais formulações explícitas das mudanças que, se espera, ocorram nos alunos mediante o processo educacional. A formulação de objetivos educacionais deve vislumbrar uma escolha consciente do docente, e ainda, um reflexo da aplicação de princípios da teoria de aprendizagem que o docente emprega (BLOOM, 1973).

No contexto do uso de tecnologias no ensino, a construção de objetivos educacionais almeja guiar o design instrucional em um processo de avaliação do conhecimento de forma mais precisa.

Ainda segundo Bloom (1973) a taxonomia de objetivos educacionais é constituída de três categorias - domínios cognitivo, afetivo e psicomotor. Para a análise dos resultados desta pesquisa, somente será considerado o domínio cognitivo. Este, inclui os objetivos vinculados à memória ou cognição e ao desenvolvimento de capacidades e habilidades intelectuais.

Os objetivos cognitivos envolvem o conhecimento de informações, ideias e conceitos. Bloom divide o domínio cognitivo em seis níveis de aprendizagem que se sucedem na seguinte 
ordem: conhecimento, compreensão, aplicação, análise, síntese, avaliação (PERES; LEITE,2000). 


\begin{tabular}{|c|c|}
\hline Categoria & Descrição \\
\hline \multirow[t]{3}{*}{ 1. Conhecimento } & $\begin{array}{l}\text { Definição: Habilidade de lembrar informações e conteúdos previamente abordados como fatos, datas, } \\
\text { palavras, teorias, métodos, classificações, lugares, regras, critérios, procedimentos etc. A habilidade } \\
\text { pode envolver lembrar uma significativa quantidade de informação ou fatos específicos. O objetivo } \\
\text { principal desta categoria nível é trazer à consciência esses conhecimentos. }\end{array}$ \\
\hline & $\begin{array}{l}\text { Subcategorias: } 1.1 \text { Conhecimento específico: Conhecimento de terminologia; Conhecimento de } \\
\text { tendências e sequências; } 1.2 \text { Conhecimento de formas e significados relacionados às especificidades } \\
\text { do conteúdo: Conhecimento de convenção; Conhecimento de tendência e sequência; Conhecimento } \\
\text { de classificação e categoria; Conhecimento de critério; Conhecimento de metodologia; e } 1.3 \\
\text { Conhecimento universal e abstração relacionado a um determinado campo de conhecimento: } \\
\text { Conhecimento de princípios e generalizações; Conhecimento de teorias e estruturas. }\end{array}$ \\
\hline & $\begin{array}{l}\text { Verbos: enumerar, definir, descrever, identificar, denominar, listar, nomear, combinar, realçar, apontar, } \\
\text { relembrar, recordar, relacionar, reproduzir, solucionar, declarar, distinguir, rotular, memorizar, ordenar } \\
\text { e reconhecer. }\end{array}$ \\
\hline \multirow[t]{3}{*}{ 2. Compreensão } & $\begin{array}{l}\text { Definição: Habilidade de compreender e dar significado ao conteúdo. Essa habilidade pode ser } \\
\text { demonstrada por meio da tradução do conteúdo compreendido para uma nova forma (oral, escrita, } \\
\text { diagramas etc.) ou contexto. Nessa categoria, encontra-se a capacidade de entender a informação ou } \\
\text { fato, de captar seu significado e de utilizá-la em contextos diferentes. }\end{array}$ \\
\hline & Subcategorias: 2.1 Translação; 2.2 Interpretação e 2.3 Extrapolação. \\
\hline & $\begin{array}{l}\text { Verbos: alterar, construir, converter, decodificar, defender, definir, descrever, distinguir, discriminar, } \\
\text { estimar, explicar, generalizar, dar exemplos, ilustrar, inferir, reformular, prever, reescrever, resolver, } \\
\text { resumir, classificar, discutir, identificar, interpretar, reconhecer, redefinir, selecionar, situar e traduzir. }\end{array}$ \\
\hline \multirow[t]{2}{*}{ 3. Aplicação } & $\begin{array}{l}\text { Definição: Habilidade de usar informações, métodos e conteúdos aprendidos em novas situações } \\
\text { concretas. Isso pode incluir aplicações de regras, métodos, modelos, conceitos, princípios, leis e teorias. }\end{array}$ \\
\hline & $\begin{array}{l}\text { Verbos: aplicar, alterar, programar, demonstrar, desenvolver, descobrir, dramatizar, empregar, ilustrar, } \\
\text { interpretar, manipular, modificar, operacionalizar, organizar, prever, preparar, produzir, relatar, resolver, } \\
\text { transferir, usar, construir, esboçar, escolher, escrever, operar e praticar. }\end{array}$ \\
\hline \multirow[t]{2}{*}{ 4. Análise } & $\begin{array}{l}\text { Definição: Habilidade de subdividir o conteúdo em partes menores com a finalidade de entender a } \\
\text { estrutura final. Essa habilidade pode incluir a identificação das partes, análise de relacionamento entre } \\
\text { as partes e reconhecimento dos princípios organizacionais envolvidos. Identificar partes e suas inter- } \\
\text { relações. Nesse ponto é necessário não apenas ter compreendido o conteúdo, mas também a estrutura } \\
\text { do objeto de estudo. }\end{array}$ \\
\hline & $\begin{array}{l}\text { Subcategorias: Análise de elementos; Análise de relacionamentos; e Análise de princípios } \\
\text { organizacionais. }\end{array}$ \\
\hline 4. Análise & $\begin{array}{l}\text { Verbos: analisar, reduzir, classificar, comparar, contrastar, determinar, deduzir, diagramar, distinguir, } \\
\text { diferenciar, identificar, ilustrar, apontar, inferir, relacionar, selecionar, separar, subdividir, calcular, } \\
\text { discriminar, examinar, experimentar, testar, esquematizar e questionar. }\end{array}$ \\
\hline \multirow[t]{3}{*}{ 5. Síntese } & $\begin{array}{l}\text { Definição: Habilidade de agregar e juntar partes com a finalidade de criar um novo todo. Essa } \\
\text { habilidade envolve a produção de uma comunicação única (tema ou discurso), um plano de operações } \\
\text { (propostas de pesquisas) ou um conjunto de relações abstratas (esquema para classificar informações). } \\
\text { Combinar partes não organizadas para formar um "todo". }\end{array}$ \\
\hline & $\begin{array}{l}\text { Subcategorias: } 5.1 \text { Produção de uma comunicação original; } 5.2 \text { Produção de um plano ou propostas de } \\
\text { um conjunto de operações; e } 5.3 \text { Derivação de um conjunto de relacionamentos abstratos. }\end{array}$ \\
\hline & $\begin{array}{l}\text { Verbos: categorizar, combinar, compilar, compor, conceber, construir, criar, desenhar, elaborar, } \\
\text { estabelecer, explicar, formular, generalizar, inventar, modificar, organizar, originar, planejar, propor, } \\
\text { reorganizar, relacionar, revisar, reescrever, resumir, sistematizar, escrever, desenvolver, estruturar, } \\
\text { montar e projetar. }\end{array}$ \\
\hline \multirow[t]{3}{*}{ 6. Avaliação } & $\begin{array}{l}\text { Definição: Habilidade de julgar o valor do material (proposta, pesquisa, projeto) para um propósito } \\
\text { específico. O julgamento é baseado em critérios bem definidos que podem ser externos (relevância) } \\
\text { ou internos (organização) e podem ser fornecidos ou conjuntamente identificados. Julgar o valor do } \\
\text { conhecimento. }\end{array}$ \\
\hline & $\begin{array}{l}\text { Subcategorias: } 6.1 \text { Avaliação em termos de evidências internas; e } 6.2 \text { Julgamento em termos de } \\
\text { critérios externos. }\end{array}$ \\
\hline & $\begin{array}{l}\text { Verbos: Avaliar, averiguar, escolher, comparar, concluir, contrastar, criticar, decidir, defender, } \\
\text { discriminar, explicar, interpretar, justificar, relatar, resolver, resumir, apoiar, validar, escrever um review } \\
\text { sobre, detectar, estimar, julgar e selecionar. }\end{array}$ \\
\hline
\end{tabular}

Figura 6: Estruturação da Taxonomia de Bloom no domínio cognitivo. (Fonte: FERRAZ; BELHOT, 2010). 
Ao fundamentarmos a análise dos dados no domínio cognitivo da Taxonomia, busca-se obter uma melhor compreensão sobre o que era pretendido com a aula virtual construída pelo licenciando nessa perspectiva. O objetivo do uso da taxonomia de Bloom é mensurar o nível de congruência entre o que era proposto na aula virtual, atividades instrucionais e métodos de avaliação do conhecimento.

A Taxonomia de Bloom não está limitada a nenhuma modalidade educacional específica, ela não está relacionada à modalidade na qual a educação acontece (presencial ou a distância), e, sim, à efetividade do processo educacional, pois é o "como" implementar objetivos, estratégias e conteúdo que realmente importa, e não a forma ou o ambiente na qual a aprendizagem ocorrerá (FERRAZ; BELHOT, 2010).

Das 33 aulas virtuais, somente uma aula não continha os objetivos expressos, isso reflete a preocupação do licenciando em determinar objetivos para ações educativas. Embora, através da análise das matrizes construídas, torna-se evidente a dificuldade dos licenciandos em expor os objetivos da aula adequados à modalidade online.

Nenhuma aula virtual atingiu os seis níveis propostos segundo a taxonomia de Bloom, a grande maioria se situou nos níveis iniciais de conhecimento e compreensão, como exemplifica a figura a seguir. 


\begin{tabular}{l|l} 
UNIDADE & \multicolumn{1}{c}{ OBJETIVOS } \\
& $\begin{array}{l}\text { 1. conhecer as técnicas de preparo e administração de medicamentos pelas vias } \\
\text { intradérmica, intramuscular, subcutânea e intravenosa }\end{array}$ \\
Aula 3 & $\begin{array}{l}\text { 2. aplicá-las corretamente na prática } \\
\text { 3. realizar esses procedimentos com competência }\end{array}$ \\
\hline Aula 14 & $\begin{array}{l}\text { 1. Compreender os conceitos acerca da demência } \\
\text { 2. Compreender e assimilar a assistência de enfermagem a ser oferecida } \\
\text { 3. Discutir os itens supra abordados }\end{array}$ \\
\hline Aula 19 & $\begin{array}{l}\text { 1. Conhecer algumas das doenças ginecológicas } \\
\text { 2. Compreender a fisiopatologia das doenças ginecológicas } \\
\text { 3. Identificar o desenvolvimento da doença } \\
\text { 4. Relacionar os cuidados de enfermagem com as doenças ginecológicas }\end{array}$ \\
\hline Aula 32 & $\begin{array}{l}\text { 1. Relembrar a anatomia e fisiologia do sistema urinário } \\
\text { 2. Discorrer sobre insuficiência renal aguda e insuficiência real crônica } \\
\text { 3. Construir o papel do técnico de enfermagem frente ao doente renal }\end{array}$
\end{tabular}

Figura 7: Exemplos de objetivos selecionados das matrizes.

Outro aspecto relevante é que os objetivos das aulas são, dentro da perspectiva da formação de futuros docentes de enfermagem, mal formulados pois não são específicos acerca das habilidades e competências para o público da aula virtual.

O desafio de avaliar o que foi aprendido pelo aluno torna-se ainda maior quando os objetivos não são bem formulados. Ansiedade e frustração surgem quando os docentes não possuem uma compreensão adequada do objetivo pretendido, da importância do conteúdo abordado e das técnicas instrucionais utilizadas, além da concordância desses itens com os critérios de avaliação do aprendizado (FERRAZ; BELHOT, 2010).

A deficiência na formulação de objetivos educacionais reflete o despreparo do futuro docente no planejamento de uma ação educativa, isso não somente em ambiente virtual mas também em aulas presenciais.

Portanto, não basta apenas ter uma vaga noção dos objetivos, é necessário especificá-los de maneira clara e precisa, para que possam, efetivamente, orientar e direcionar atividades de ensino aprendizagem (HAIDT, 2002). 
Evidencia-se a necessidade de aperfeiçoamento e familiarização do profissional educador com instrumentos, como por exemplo a taxonomia de Bloom, para auxiliar na definição de objetivos para as atividades que pretende realizar.

\subsection{PAPÉIS}

Esse item define quem são os responsáveis pelas atividades dentro da unidade de aprendizagem, orientados para que os objetivos sejam alcançados. Neste item tornam-se pertinentes as ações docentes e as ações discentes.

Haviam dois papéis possíveis dentro das aulas virtuais criadas: o papel de apoio e o de aprendizagem. Todas as unidades, através da análise das matrizes, apresentaram o papel de apoio e de aprendizagem. O primeiro relacionado à ação docente (no caso, licenciando em enfermagem) e o segundo papel, o de aprendizagem, para alunos da educação profissional técnica de nível médio em enfermagem, público alvo das aulas virtuais.

A concepção pedagógica que o professor carrega é o determinante que subsidia as suas ações, norteia sua prática, seja em qual modalidade de ensino for, presencial ou à distância, o professor e suas concepções sempre serão a chave do processo. (PEREIRA, RESENDE, 2013). As tecnologias e o ambiente virtual subsidiam o docente na tarefa de organizador das atividades de ensino, mas não o isentam da ação de desenvolver um processo de ensino aprendizagem.

Quando a ação docente é realizada no ambiente virtual, pode evidenciar a necessidade de apoio de um maior número de professores, devido ao grande volume de material educativo para ser administrado e a dinâmica do conteúdo online. 


\subsection{ATIVIDADES}

Os licenciandos planejaram atividades diversificadas e criativas, tiveram como disparadores cognitivos atividades práticas relacionadas ao contexto social, acadêmico e de saúde do públicoalvo. As atividades, de complexidade variada, contemplaram leituras de artigos, visualização de slides, a resolução de estudo de caso e até a pesquisa online.

Ao propor atividades práticas, que abordam questões frequentemente encontradas na área da saúde, o exercício de reflexão durante as atividades desempenhadas pelo licenciando mobiliza o aluno para a construção de seu conhecimento.

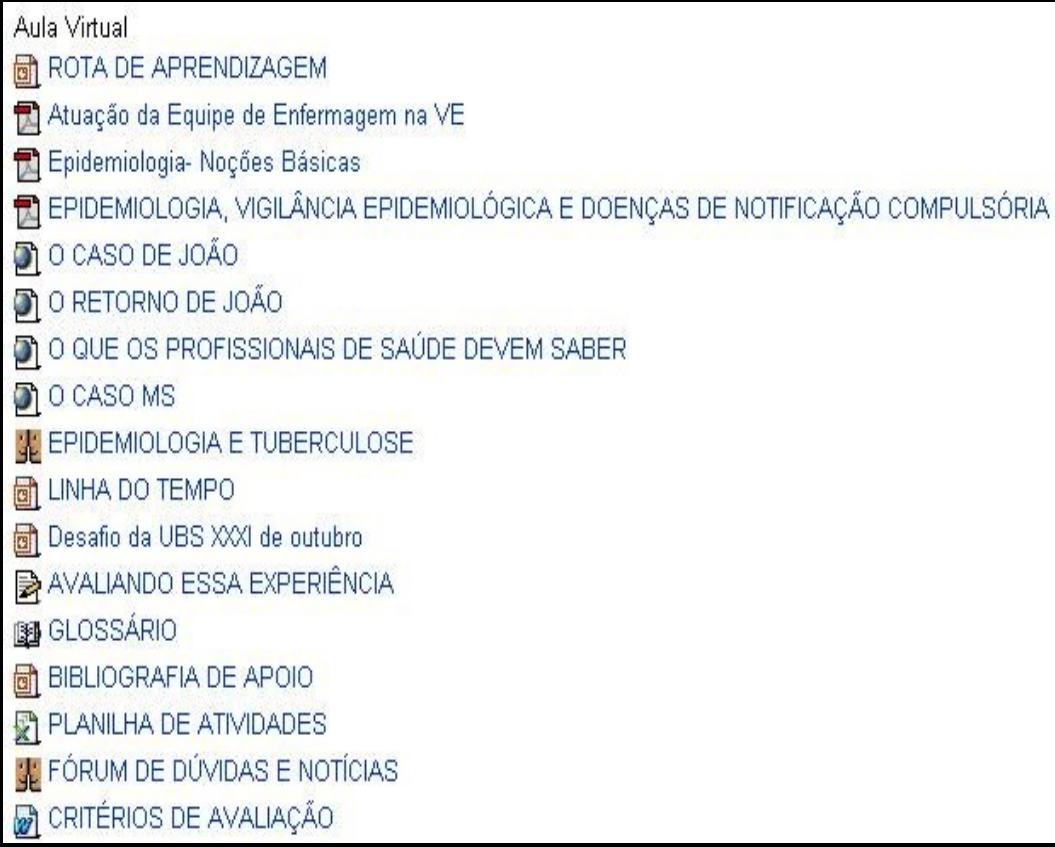

Figura 8: Exemplo da ordem das atividades apresentadas em aula virtual. Fonte: Moodle 2014. 


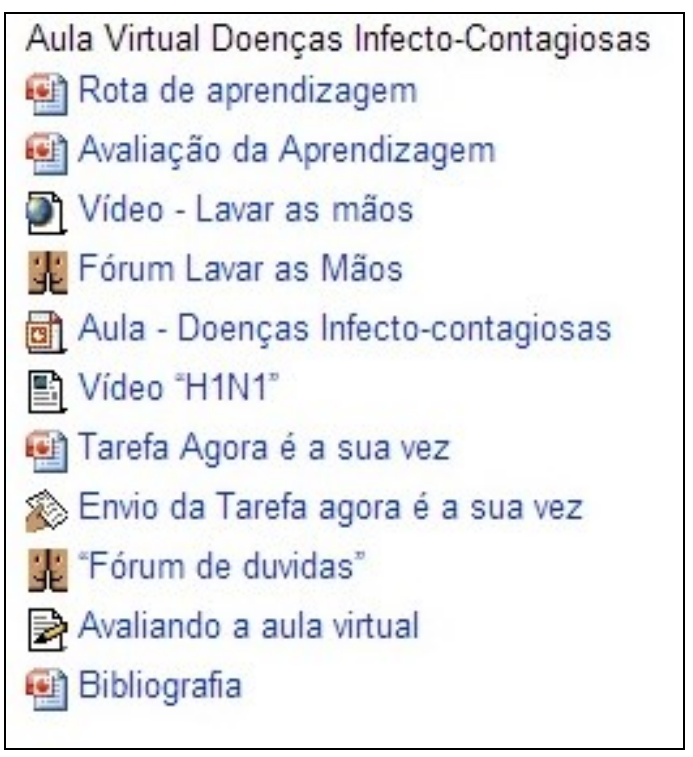

Figura 9: Exemplo da ordem das atividades apresentadas em aula virtual. Fonte: Moodle, 2014.

Nota-se que emerge um padrão na sequência das atividades propostas para a maioria das aulas. Dentro do design instrucional, a estrutura que mais se repetiu nas matrizes de cada aula foi: Apresentação, vídeo, fórum virtual, tarefa e avaliação. A estrutura formulada para a aula virtual reflete a metodologia de ensino que o licenciando buscou utilizar.

Segundo Prado (2013 apud Rego, 2011) é interessante destacar o papel da imitação no aprendizado, pois Vygotsky considera que esta oferece a oportunidade de reconstrução interna daquilo que o indivíduo observa externamente, em um processo de internalização. Pode também assumir um papel estruturante, pois amplia a capacidade cognitiva individual.

Este fato pode ser constatado em diversas aulas virtuais construídas pelos licenciados através da análise da semelhança destas com as aulas que os próprios alunos tiveram previamente durante o curso de licenciatura, configurando a imitação no aprendizado. 


\subsection{CARGA HORÁRIA}

A duração da unidade de aprendizagem virtual, 4 horas, havia sido estipulada e informada aos licenciandos anteriormente, sendo obrigatório que as aulas virtuais respeitassem esse limite.

Na maioria das aulas, o tempo estabelecido para realização das atividades foi respeitado. A dificuldade no ajuste à carga horária se faz presente quando quantificamos o número de atividades propostas em relação à carga horária máxima estipulada.

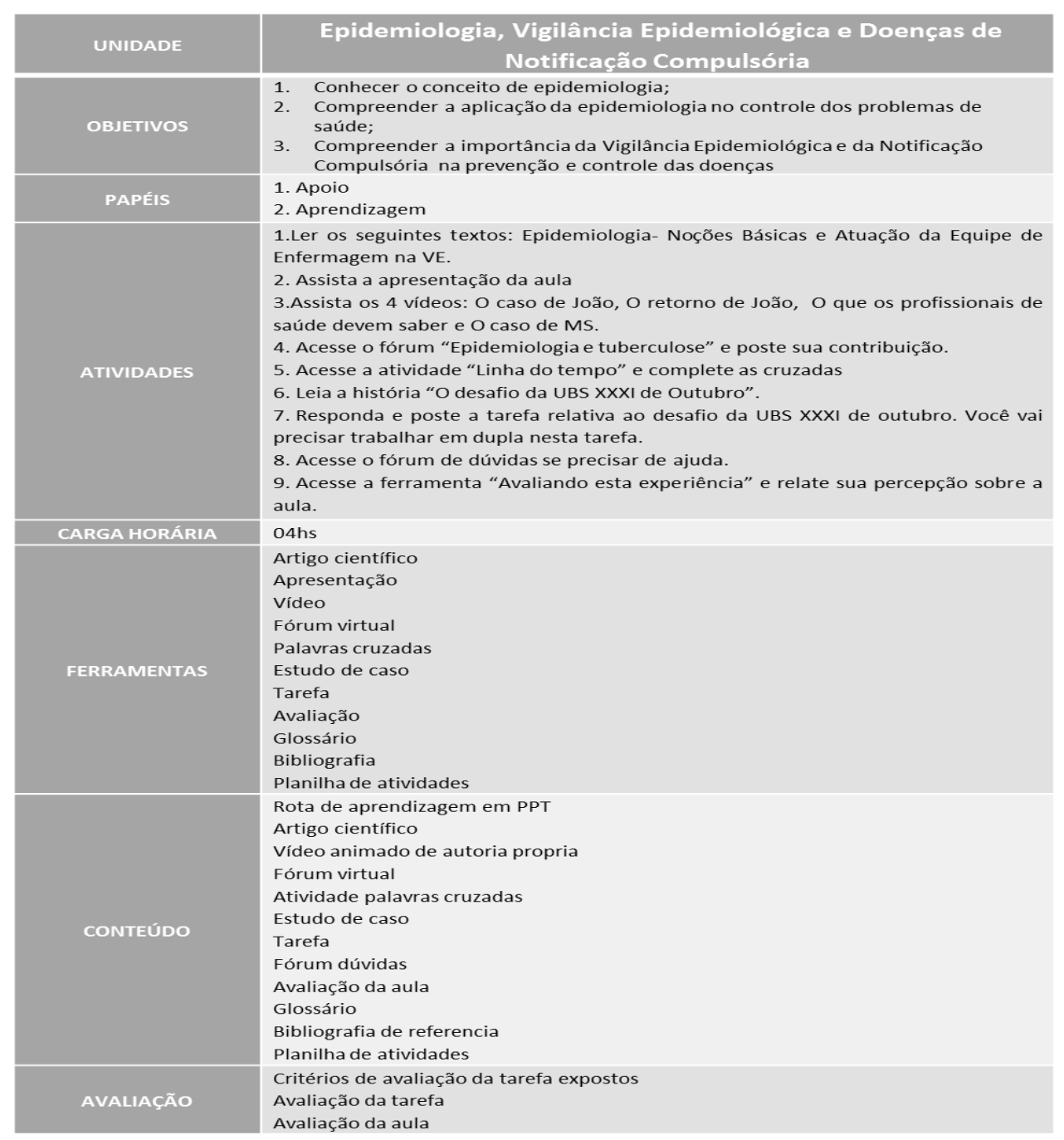

Figura 10: Matriz da aula virtual 17, duração da carga horária prevista excedente.

A aula virtual 17 é um exemplo da dificuldade de ajuste do número de atividades propostas à carga horária de 4 horas prevista. 
Percebe-se nesses casos que o licenciando não contabilizou o tempo que seria gasto para que a tarefa fosse realizada dentro da carga horária total.

Ao analisarmos a matriz da aula 17 , dentro do item atividades, foram propostas 9 atividades que se desdobram em outras ações e incluem elaboração de tarefas, visualização de vídeos, leitura de textos e discussão em fórum, todas atividades que demandam muito tempo do aluno para a sua finalização.

Em contrapartida, temos o exemplo da aula virtual 14 onde foram propostas somente 4 atividades, sendo que 0 item 4 (Pesquisar artigos direcionados para discussão em um segundo momento) infere que este item será realizado posteriormente e não dentro das 4 horas previstas.

\begin{tabular}{|c|c|}
\hline UNIDADE & Demência \\
\hline OBJETIVOS & $\begin{array}{l}\text { 1. Compreender os conceitos acerca da demência } \\
\text { 2. Compreender e assimilar a assistência de enfermagem a ser oferecida } \\
\text { 3. Discutir os itens supra abordados }\end{array}$ \\
\hline PAPÉIS & $\begin{array}{l}\text { 1. Apoio } \\
\text { 2. Aprendizagem }\end{array}$ \\
\hline ATIVIDADES & $\begin{array}{l}\text { 1.Assistir a apresentação } \\
\text { 2.Assistir aos vídeos com casos práticos sobre apraxia, agnosia e afasia } \\
\text { 3.Abertura para discussão e levantamento de dúvidas } \\
\text { 4. Pesquisar artigos direcionados para discussão em um segundo momento }\end{array}$ \\
\hline CARGA HORÁRIA & $04 \mathrm{hs}$ \\
\hline FERRAMENTAS & $\begin{array}{l}\text { Apresentação } \\
\text { Vídeos } \\
\text { Pesquisa online } \\
\text { Avaliação }\end{array}$ \\
\hline CONTEÚDO & $\begin{array}{l}\text { Rota de aprendizagem em Powerpoint } \\
\text { Vídeos no Youtube } \\
\text { Slides da aula em Powerpoint }\end{array}$ \\
\hline AVALIAÇÃO & $\begin{array}{l}\text { Autoavaliação } \\
\text { Avaliação da aula }\end{array}$ \\
\hline
\end{tabular}

Figura 11: Matriz da aula virtual 14, duração da carga horária prevista incipiente.

Aula virtuais elaboradas somente com vídeos e a apresentação do conteúdo através de slides, oferecem poucas 
oportunidades de reflexão dentro da unidade, dessa maneira ficaram aquém da carga horária esperada.

A carga horária incipiente impacta na aprendizagem do conteúdo, em especial na adesão e comprometimento do aluno para o qual a unidade foi proposta, assim torna-se muito difícil avaliar se os objetivos propostos foram alcançados.

A adequação da carga horária em ambientes virtuais de aprendizagem é um dos aspectos mais difíceis no uso de tecnologias educacionais, devido à complexidade de o docente calcular o tempo para que o aluno realize cada atividade proposta. Deve-se levar em consideração que o ambiente virtual é dinâmico e o acesso à internet influencia muito no número de atividades concomitantes que o aluno desempenha junto com a aula virtual. Além é claro da individualidade, disponibilidade de tempo e ritmo pessoal de cada estudante.

Atualmente, existe muita dificuldade em encontrar referencial teórico para embasar o planejamento adequado da carga horária em ambientes virtuais de aprendizagem.

Portanto, é preciso que o docente esteja ciente e utilize-se de treinos prévios e estimativas de tempo de execução da tarefa, tanto no âmbito individual como coletivo.

Em algumas unidades de aprendizagem foram propostas atividades em dupla sem nenhum planejamento especial em relação ao tempo gasto para que isso se tornasse possível, ficando evidente a dificuldade de adequação da carga horária pré-determinada ao tempo real da atividade online.

Para que o trabalho colaborativo seja eficiente no ambiente virtual é imprescindível um controle rigoroso da carga horária para cada atividade prevista. 
A prática tem mostrado que o trabalho em colaboração é muito mais produtivo para a aprendizagem dos alunos: especialmente as duplas (mas também os trios e grupos de quatro) têm se revelado uma boa opção se os critérios de agrupamento forem adequados. Esse tipo de agrupamento favorece que os alunos socializem seus conhecimentos, podendo confrontar e compartilhar suas hipóteses, trocando informações, aprendendo diferentes procedimentos, defrontandose com problemas sobre os quais não haviam pensado... (SOLIGO, 2012, pag. 10)

Para organizar os agrupamentos é preciso considerar os objetivos da atividade proposta, o conhecimento que os alunos possuem e a natureza da atividade (SOLIGO, 2012). Nas aulas virtuais, a proposta também deve se adequar à possibilidade dos alunos em se reunirem virtualmente ou o docente apresentar outras soluções para que a socialização se concretize.

\subsection{AMBIENTE: FERRAMENTAS E CONTEÚDOS}

Dentro do item ambiente foram listados quais os recursos e materiais necessários para desenvolver determinada atividade.

A apresentação quantitativa dos objetos de aprendizagem utilizados pelos licenciandos visa oferecer uma compreensão ampliada da estrutura das aulas virtuais, buscando identificar padrões na escolha de recursos didáticos pelos licenciandos.

A construção do gráfico abaixo buscou elucidar os objetos de aprendizagem utilizados. Todos os itens foram acessados e agrupados segundo o objetivo de cada item proposto pelo licenciando.

Os itens em destaque na Tabela 1 (vídeo no Youtube, slides em PowerPoint ou PDF e fórum virtual) apresentaram utilização maior do que somente um item por aula, ou seja, em algumas aulas 
virtuais mais de um objeto de aprendizagem deste tipo foi utilizado dessa maneira justificando a porcentagem acima de $100 \%$.

O elevado percentual de utilização destes três itens reflete as concepções pedagógicas e experiências prévias dos licenciandos com estes objetos de aprendizagem no ambiente virtual.

\begin{tabular}{|c|c|c|}
\hline $\begin{array}{c}\text { Objeto de } \\
\text { aprendizagem }\end{array}$ & Total utilizado & Média de uso \\
\hline Vídeo no Youtube & 72 & $218,2 \%$ \\
\hline $\begin{array}{c}\text { Slides em PowerPoint } \\
\text { ou PDF }\end{array}$ & 44 & $133,3 \%$ \\
\hline Fórum & 36 & $109,1 \%$ \\
\hline Artigo Científico & 31 & $93,9 \%$ \\
\hline Rota de Aprendizagem & 30 & $90,9 \%$ \\
\hline Avaliação da aula virtual & 26 & $78,8 \%$ \\
\hline Envio de Tarefa online & 24 & $72,7 \%$ \\
\hline $\begin{array}{c}\text { Referências } \\
\text { Bibliográficas }\end{array}$ & 23 & $69,7 \%$ \\
\hline Critérios para Avaliação & 22 & $66,7 \%$ \\
\hline $\begin{array}{c}\text { Personagem Tutor } \\
\text { Virtual }\end{array}$ & 10 & $30,3 \%$ \\
\hline Pesquisa online & 9 & $27,3 \%$ \\
\hline Documento no Word & 8 & $24,2 \%$ \\
\hline Ilustrações & 7 & $21,2 \%$ \\
\hline Estudo de caso & 6 & $18,2 \%$ \\
\hline Texto online & 6 & $18,2 \%$ \\
\hline $\begin{array}{l}\text { Recurso audiovisual de } \\
\text { autoria própria }\end{array}$ & 4 & $12,1 \%$ \\
\hline Chat & 3 & $9,1 \%$ \\
\hline Quizz & 3 & $9,1 \%$ \\
\hline $\begin{array}{l}\text { Atividade educativa } \\
\text { palavras-cruzadas }\end{array}$ & 2 & $6,1 \%$ \\
\hline $\begin{array}{c}\text { Biblioteca virtual } \\
\text { colaborativa }\end{array}$ & 2 & $6,1 \%$ \\
\hline $\begin{array}{l}\text { Atividade educativa } \\
\text { frases embaralhadas }\end{array}$ & 1 & $3,0 \%$ \\
\hline Glossário & 1 & $3,0 \%$ \\
\hline Planilha de atividades & 1 & $3,0 \%$ \\
\hline Plano de aula disponível & 1 & $3,0 \%$ \\
\hline
\end{tabular}

Tabela 1- Número de objetos de aprendizagem utilizados: total e média de uso nas 33 aulas virtuais 
Conforme demonstram os dados retirados das matrizes, os recursos que apareceram com maior frequência de utilização foram: Vídeo (218,2\%), slides em powerpoint ou pdf $(133,3 \%)$, fórum $(109,1 \%)$, artigo cientifico $(93,9 \%)$, avaliação da aula virtual $(78,8 \%)$, envio de tarefa online $(72,7 \%)$ e referências bibliográficas $(69,7 \%)$.

O objeto de aprendizagem construído e utilizado como recurso pedagógico interativo engloba imagens, textos, áudios, vídeos, exercícios e páginas da web (ALMEIDA, 2013).

Os objetos de aprendizagem (...) possibilitam uma facilidade no processo de ensino à medida que estendem as percepções dos cinco sentidos, representando mais concretamente o real estado das coisas. Esses novos recursos fazem com que o conhecimento passe a ser construído buscando-se a informação e explorando-se um dado como se de fato ele existisse, fazendo-o concreto e autêntico com relação e utilidade no mundo real, o que pode proporcionar mais motivação ao estudante (PRADO et al, 2011, pág. 86).

A elaboração e construção das ferramentas necessita de grande dedicação de tempo do licenciando e articulação para a realidade do ambiente virtual.

Para desenvolver a educação a distância com suporte em ambientes digitais e interativos de aprendizagem torna-se necessária a preparação de profissionais que possam implementar recursos tecnológicos (software) condizentes com as necessidades educacionais, o que implica estruturar equipes interdisciplinares constituídas por educadores, profissionais de design, programação e desenvolvimento de ambientes computacionais para EaD, com competência na criação, gerenciamento e uso desses ambientes (ALMEIDA, 2003, pág.335).

A rota de aprendizagem também surge como item expressivo. A rota de aprendizagem é uma ferramenta utilizada para que apresente cada atividade a ser realizada e para que se possa sugerir o caminho que o aluno possa percorrer na aula virtual. A finalidade é 
estruturar o caminho a ser trilhado pelo estudante no decorrer da aula estabelecendo uma comunicação tridimensional entre aluno/professor/conhecimento (PRADO et al, 2011).

Em análise quantitativa, a rota de aprendizagem foi utilizada em 30 aulas (90,9\%). Dentre as hipóteses levantadas para essa alta porcentagem de utilização podemos citar:

1. Era um item obrigatório informado aos alunos durante o início do planejamento da atividade.

2. Reflete uma necessidade dos licenciandos, pois como a aluna do Programa Aperfeiçoamento do Ensino era responsável pela inserção do conteúdo na plataforma virtual, tornou-se uma estratégia de orientação para que o conteúdo ficasse como planejado.

3. A rota de aprendizagem é presente nas aulas virtuais desenvolvidas pelos docentes da disciplina ao longo do semestre, com o qual os alunos desenvolveram certa similaridade, e portanto tornou-se um modelo ao licenciandos.

O amplo domínio do manejo da internet, de encontrar recursos audiovisuais, de criar apresentações concretiza-se através da apresentação concisa do conteúdo articulado com ferramentas como o fórum, chat e envio de tarefas online.

\footnotetext{
Ensinar em ambientes digitais e interativos de aprendizagem significa: organizar situações de aprendizagem, planejar e propor atividades; disponibilizar materiais de apoio com o uso de múltiplas mídias e linguagens; ter um professor que atue como mediador e orientador do aluno, procurando identificar suas representações de pensamento; fornecer informações relevantes, incentivar a busca de distintas fontes de informações e a realização de experimentações; provocar a reflexão sobre processos e produtos; favorecer a formalização de conceitos; propiciar a interaprendizagem e a aprendizagem significativa do aluno (ALMEIDA, 2003, pág. 334).
} 
Em plena era de surpreendentes avanços tecnológicos, os futuros docentes demonstraram fluência digital ao lidar com as ferramentas necessárias para produzir o conteúdo digital.

A seguir, os itens mais utilizados serão descritos individualmente.

\subsubsection{Vídeos}

Utilizado 72 vezes dentro das 33 aulas virtuais, com uma média de uso de $218,2 \%$, foi o objeto de aprendizagem mais selecionado pelos licenciandos.

Recursos audiovisuais evocam a imaginação, e esta se liga intimamente à afetividade, fazendo com que estudantes jovens e adultos respondam sensivelmente a essa linguagem (Moran, 2000).

O vídeo é um recurso presente no dia a dia do estudante e em especial do licenciando, pois é trabalhado em diversas aulas virtuais do curso de licenciatura e apresenta significativo potencial para instigar a reflexão e o debate.

Considerando que os estudantes têm diferentes estilos de aprendizagem, o uso do vídeo em educação respeita os múltiplos estilos de aprendizagem e de inteligência (Mattar, 2009). Respeita também a individualidade e os diferentes ritmos de aprendizagem, pois tem a possibilidade de ser assistido diversas vezes e no momento desejado.

Uma dificuldade encontrada na análise dos vídeos foi em visualizar sua articulação com o conteúdo, pois muitas vezes os vídeos escolhidos não agregaram informações ou propuseram novas reflexões, mas sim repetiram informações já contidas nos slides da aula ou nos textos disponíveis. Percebe-se que em algumas aulas o enfoque fugiu do potencial do recurso audiovisual na aprendizagem, situando-se no enfoque conteudista. 
Outros aspectos como qualidade do vídeo, linguagem, idioma e tempo de duração não foram considerados por alguns licenciandos na escolha do material.

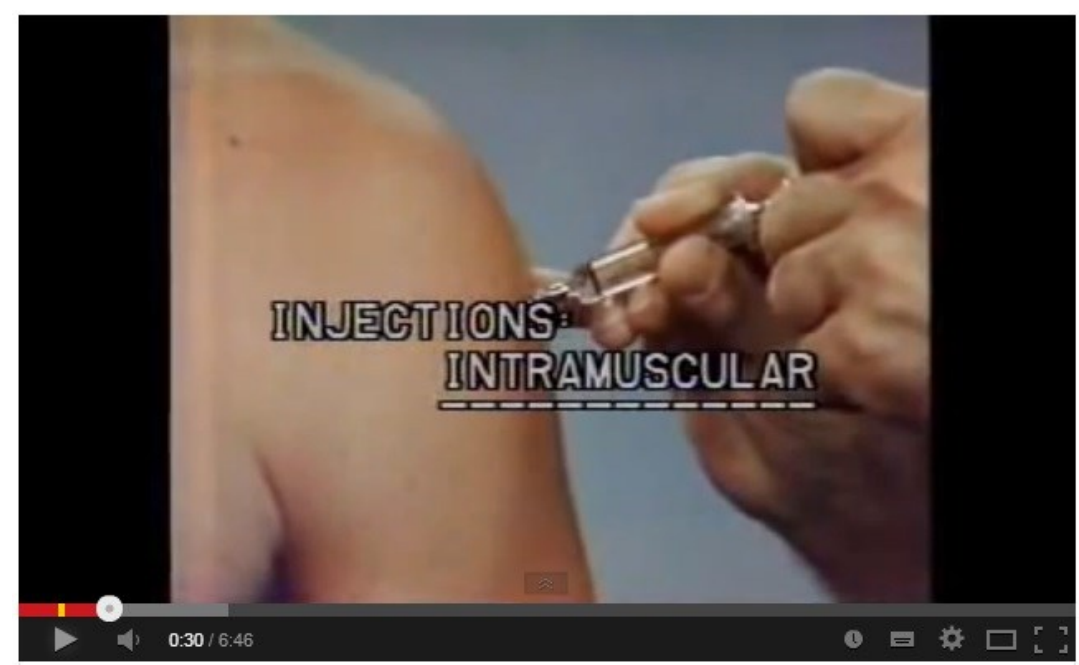

Intramuscular Injection " Deltoid, Gluteal \& Vastus Lateralis Shots "

Figura 12: Tela do vídeo de demonstração de procedimento em inglês, aula virtual 3. (Fonte: Youtube, 2014)

A aula virtual 3 é destacada nesse aspecto para elucidar a discussão devido à linguagem do vídeo selecionado pelo licenciando, que está em inglês. Embora a escolha pelo vídeo como objeto de aprendizagem em uma aula de técnica e demonstração de procedimento seja correta devido ao potencial visual, o idioma deve ser levado em consideração e somente utilizado em língua estrangeira se for pertinente ao público alvo da aula virtual.

Em contraposição, a aula virtual 6, que aborda a temática da visibilidade social da enfermagem e marketing profissional, iniciou corretamente a aula com um vídeo de um programa de televisão para incitar a discussão no chat proposto em seguida. O vídeo selecionado tem duração de seis minutos, em linguagem adequada, boa qualidade de imagem e potencializa a discussão dos alunos no chat. 


\subsubsection{Slides}

A apresentação de slides é um recurso amplamente utilizado no âmbito acadêmico presencial e na realidade da universidade na qual os licenciandos estão inseridos.

A média de utilização do recurso de apresentação de slides foi de $133,3 \%$. Os alunos construíram, no total, 44 apresentações em PowerPoint ou PDF.

Segundo Prado et al (2011) a elaboração de slides deve considerar a utilização de cores (plano de fundo), favorecendo a leiturabilidade e legibilidade; o pensamento visual: transformação de conceitos em imagens; de fotos ou imagens que representem conceitos; de metáforas; disposição das imagens nos slides de forma a criar um dinamismo na apresentação e vinculação da imagem a algum ponto do texto.

Os licenciandos demonstraram habilidade e discernimento através da construção de apresentações concisas, com conteúdo legível, formatação visualmente agradável e lógica na sequência de apresentação dos conceitos.

\subsubsection{Fórum Virtual}

Dentro das 33 aulas virtuais, foram propostos 36 fóruns $(109,1 \%)$. Em comparação entre as matrizes, os fóruns foram utilizados tanto na perspectiva de mobilização inicial do estudante para o conhecimento quanto na perspectiva de trabalhar a síntese do que foi aprendido.

Nas aulas propostas pelos licenciandos, o fórum foi uma atividade útil no desenvolvimento do processo de ensinoaprendizagem. Os fóruns propostos tinham questões norteadoras, que instigavam a discussão, apoiadas na mediação do docente, e 
portanto, sendo considerada uma ferramenta de crescimento e amadurecimento acadêmico.

O fórum virtual promove a interação social, visto que é uma das principais ferramentas desencadeadoras do aprendizado coletivo. Estimula ainda a cooperação e possibilita uma reelaboração do conhecimento por meio do processo de mediação. Constitui-se em um espaço privilegiado de aprendizagem e construção do conhecimento para que os participantes possam interagir com os demais. É o momento em que o participante supera as etapas anteriores de apropriação e análise do objeto do conhecimento e quando ocorre a sistematização, expressa a respeito do objeto apreendido, a consolidação dos conceitos (FARIA, 2010).

Em pesquisa realizada por Pereira e Resende (2013), o fórum é a ferramenta mais apreciada pelos professores pesquisados, porque é prático para o aluno tirar dúvidas; permite a interação entre os envolvidos; é lugar legítimo e democrático para o debate; espaço em que o professor avalia a organização do ensino realizada por ele para introduzir outros recursos mediadores.

Cabe ao professor saber lidar com a heterogeneidade das pessoas, saberes e experiências, diferentes ritmos, valores e atitudes, para que ocorram as interações na prática escolar, considerando sempre o sujeito ativo e interativo nesse complexo processo (PRADO, 2013).

Corroborando com o que preconiza a literatura, o fórum virtual foi uma ferramenta importante de interação social presente nas aulas virtuais pois foi sinalizada como principal forma de contato entre o docente e o aluno. 


\subsubsection{Referências Bibliográficas}

As referências bibliográficas das aulas virtuais eram atualizadas e pertinentes à temática proposta. Das 33 aulas virtuais, $23(69,7 \%)$ tinham as referências disponíveis para consulta.

Em ambiente virtual de aprendizagem, onde o aluno está conectado à internet, a disponibilização de referências bibliográficas facilita a busca por ampliar o conhecimento em determinada fonte de interesse.

\subsubsection{Glossário e Webquest: Potencial} subaproveitado

A ferramenta glossário e a ferramenta de pesquisa online, ou também denominada Webquest, são exemplos de ferramentas utilizadas em algumas aulas virtuais (embora em pequena quantidade) que merecem destaque devido ao grande potencial no ambiente virtual.

O uso do glossário é útil para o compartilhamento de palavras cujo significado seja desconhecido ou ressignifique para criação de significados compartilhados, que facilitem o diálogo. (Santos, 2006). 
A

AGENTE ETIOLÓGICO

É um microrganismo ou seu produto (toxina) ou substância capaz de produzir uma infecção ou um agravo à saúde.

Caso Autóctone

É o caso de doença que teve origem dentro dos limites de lugar em referência ou sobre investigação.

CASO IMPORTADO

Doente que adquiriu a doença em outra região de onde emigra ou onde esteve ocasionalmente.

COMUNICANTE

É a pessoa ou animal que teve contato com pessoa ou animal infectado ou com ambiente contaminado, de forma a ter oportunidade de adquirir o agente etiológico de uma doenca

Figura 13: Glossário criado e preenchido para aula virtual 17.

Dentro da aula virtual 17, o licenciando elaborou o glossário, propôs 26 termos iniciais e convidou os alunos a participarem da atividade contribuindo com mais palavras.

Em relação à proposição da realização de pesquisa online, que também pode ser denominada Webquest, ocorreu em 9 aulas $(27,3 \%)$.

O conceito de Webquest foi desenvolvido em 1995 por Bernie Dodge, na Califórnia, EUA, como uma proposta metodológica para direcionar o bom uso da internet para informação, pesquisa e desenvolvimento de atividades que são orientadas por um professor, requerem uma elevação na forma de pensar, incluem senso crítico, síntese, análise, resolução de problemas e criatividade (Webquest, 2014). 
Embora a pesquisa online proposta pelos licenciandos não caracterize inteiramente uma Webquest, a iniciativa de propor uma pesquisa online, ampliando as possibilidades dentro do ambiente virtual, é muito interessante e condizente com o ensino reflexivo.

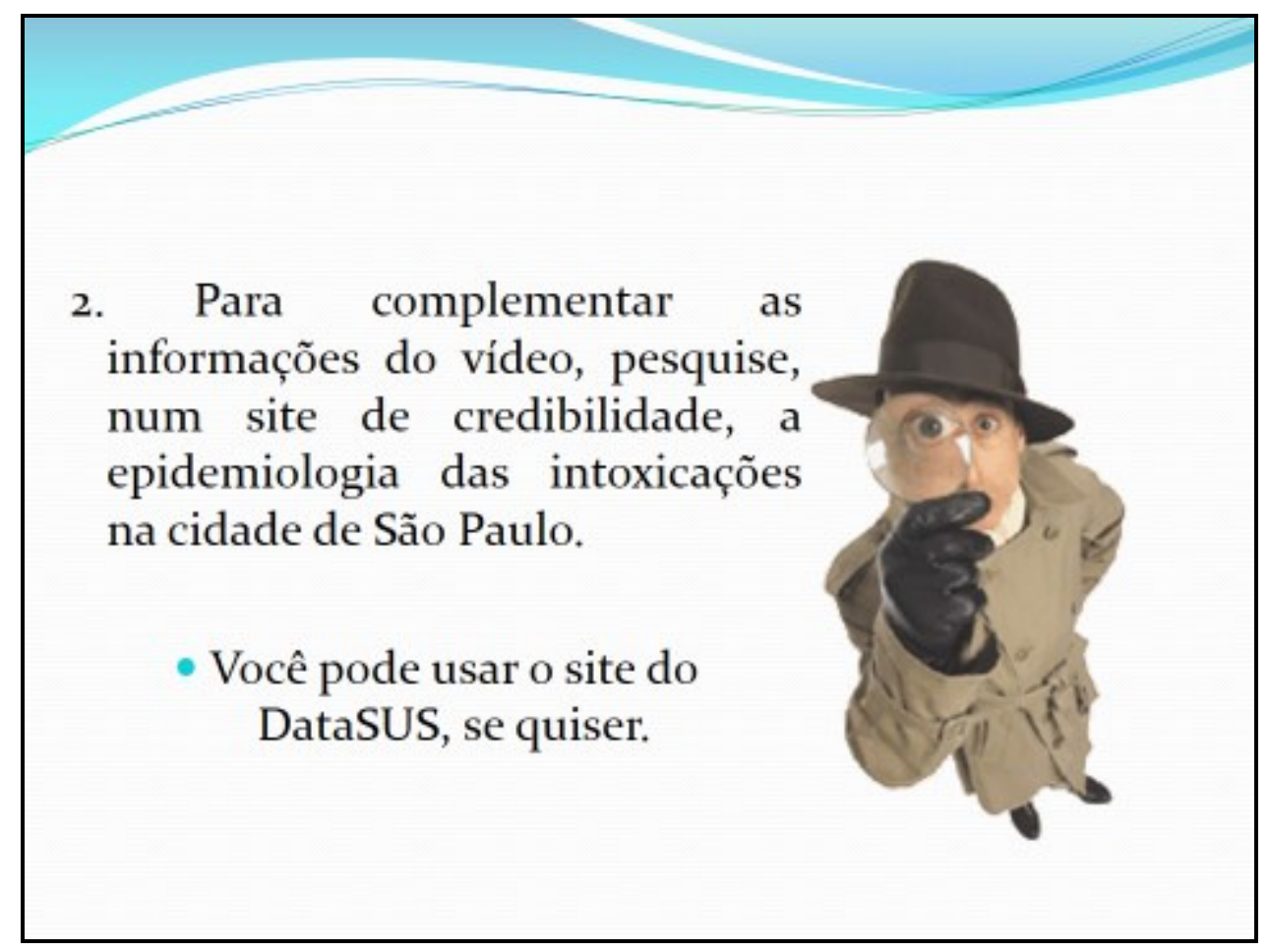

Figura 14: Tela da aula virtual 1, proposição de pesquisa online.

\subsubsection{Plano de aula: Utilização incipiente}

A preocupação em torno da formação do licenciando, para uma atuação competente em docência, evidencia-se quando este mostra dificuldades em fazer uso de recursos que o auxiliem a organizar e planejar uma atividade educativa.

Dentre todas as aulas virtuais, somente uma apresentou o plano de aula disponível $(3,0 \%)$ demostrando uma escassa utilização deste importante recurso.

O plano de aula tem como finalidade assegurar um ensino de qualidade, evitar a improvisação e a rotina pela organização e coordenação do trabalho docente; prever objetivos, conteúdos e métodos com base nas exigências da realidade social, do nível de preparo e das condições socioeconômicas 
e culturais dos educandos; garantir economia de tempo e energia; promover a eficiência do ensino (PRADO, 2013, p. 105)

Sua importância se reforça à medida que é um instrumento valioso ao licenciando, ainda inexperiente na docência e em especial no ensino online.

A atividade docente precisa ser organizada e planejada a fim de atingir os objetivos propostos para a construção do saber. $O$ plano de aula não é uma ferramenta pedagógica isolada, deve ser compreendida como parte integrante do universo dos instrumentais didático-pedagógicos (OLIVEIRA, 2011).

Portanto, planejar a atividade educativa impacta na qualidade de seu resultado final.

O conteúdo apresentado nas aulas foi muito criativo. Surgiram aulas virtuais surpreendentes, de alta qualidade e muito bem trabalhados dentro das perspectivas andragógicas e dialéticas, por exemplo.

A variedade dos temas reflete a amplitude da atuação do licenciando de enfermagem frente à educação profissional técnica de nível médio em enfermagem.

O banco de dados das aulas produzidas é um excelente material para estudantes de enfermagem. 


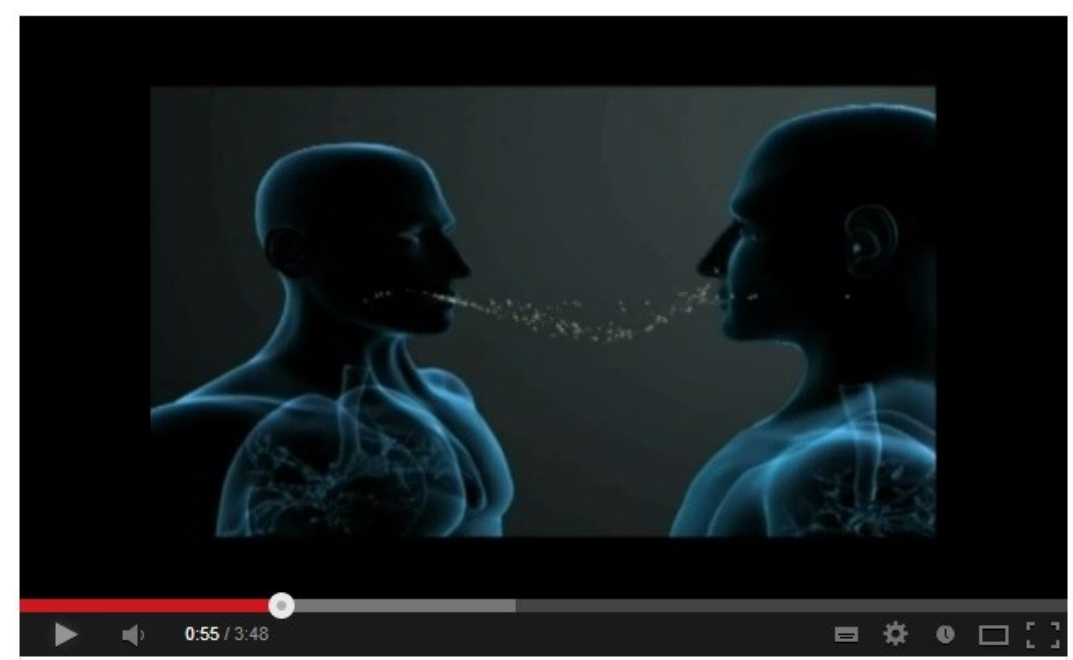

Figura 15: Tela de vídeo selecionado no Youtube para a aula virtual 6 sobre a temática Hanseníase.

Os licenciandos comprovaram que não somente conseguem selecionar bom conteúdo, mas também conseguem produzir conteúdo online. Não foram observadas dificuldades técnicas na criação das aulas, comprovando que a fluência digital observada anteriormente é pertinente. Os futuros docentes demonstraram ampla capacidade de buscar conteúdo online, visualizar vídeos, carregar arquivos, disponibilizar informações.

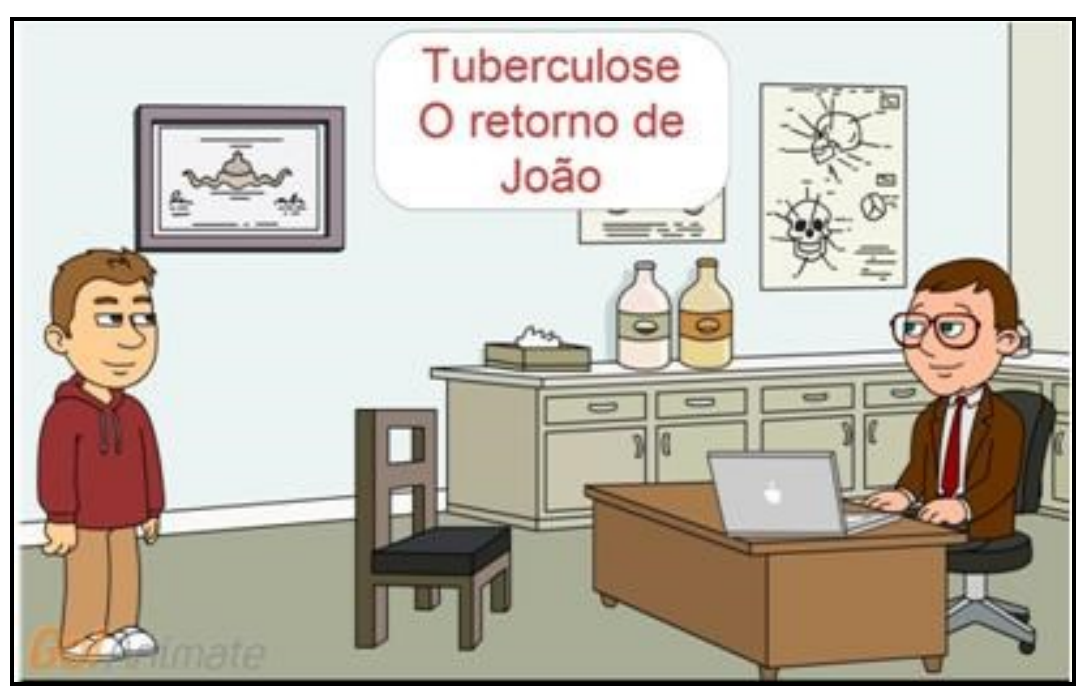

Figura 16: Ilustração do vídeo animado produzido pelo licenciando na aula virtual 17 
Fica claro, através das ferramentas utilizadas, que os alunos conhecem as facilidades do ambiente virtual MOODLE, familiaridade esta adquirida quando eles realizaram anteriormente aulas virtuais do curso. Por exemplo, sabem quando utilizar a ferramenta fórum e quando utilizar o chat e adequam a aula com a necessidade de ferramentas síncronas ou assíncronas.

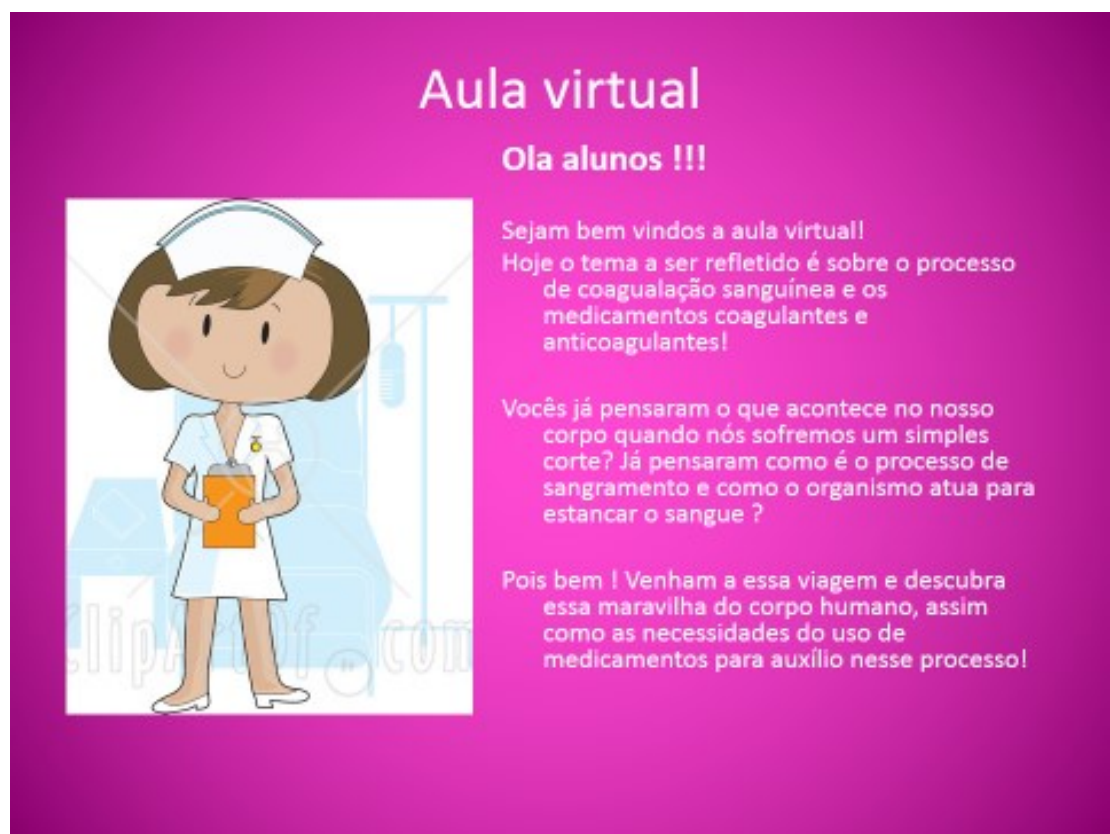

Figura 17: Tela inicial da aula virtual número 13.

A criação de personagens para serem tutores virtuais, a atribuição de nomes e caracterização ao personagem de excelente qualidade demonstram o interesse do licenciando em criar um vínculo com o aluno para qual propõe a aula, estabelecendo um elo mais forte e atraente. 


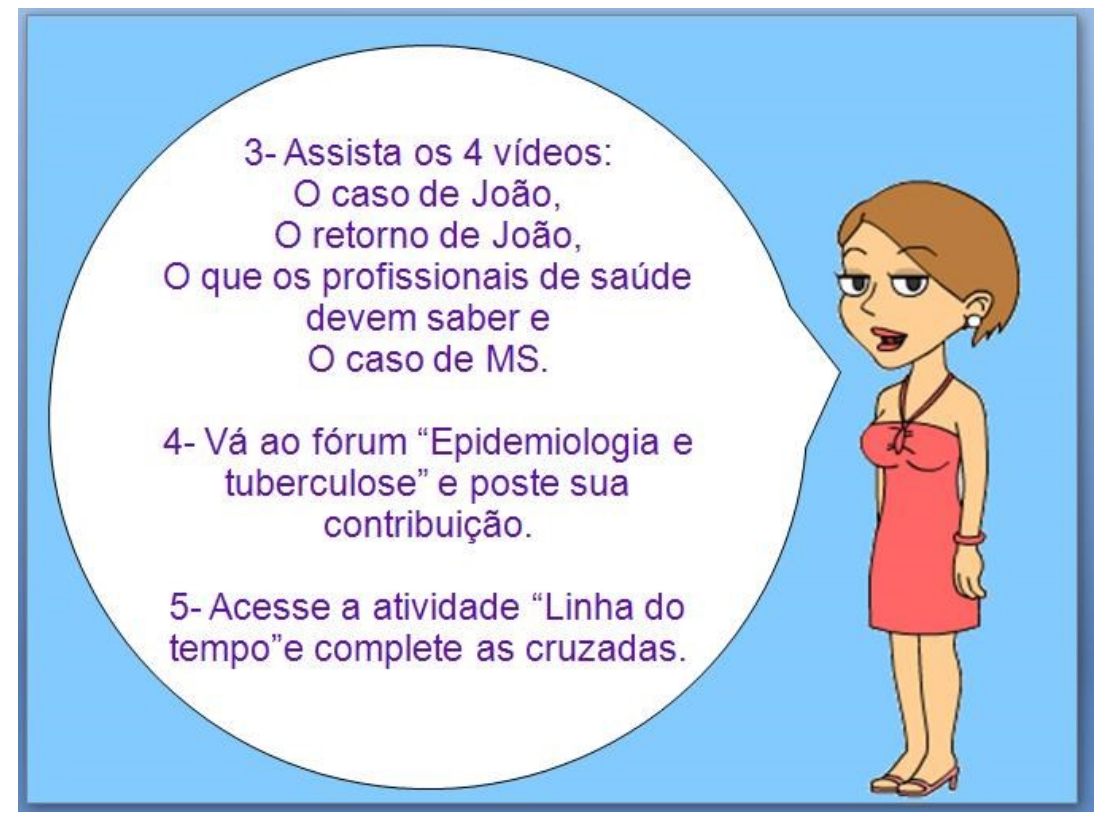

Figura 18: Tutora virtual criada para auxiliar na explicação da rota de aprendizagem.

A busca pelo vínculo com o educando é recorrente na aula dos licenciandos. Seja por meio da criação de personagens como tutores virtuais, seja por meio da linguagem utilizada.

A facilidade demonstrada em criar proximidade com o público através do uso da linguagem é admirável. Os licenciados utilizaram expressões como a tarefa intitulada "Agora é sua vez!". Diferentes títulos criativos foram atribuídos aos fóruns:

Por que devo?

Fala que eu te escuto

O que eu vejo?

$\mathrm{O}$ que sei e o que quero saber.

\subsection{AVALIAÇÃO}

O item avaliação exemplificou o desafio de realiza-la em ambiente virtual através da dificuldade apresentada pelos 
licenciandos em propor estratégias e/ou instrumentos para a avaliação do conteúdo aprendido.

A avaliação, independente se no ambiente virtual ou no ambiente presencial, continua sendo uma grande dificuldade do docente.

O que ocorre entre os indivíduos de um curso na
cibercultura não pode ser comparado com as
avaliações tradicionais, nas quais critérios são
fixados rigidamente de forma unidirecional pela
escola. Ao contrário, a avaliação deve acompanhar
a dinamicidade da rede que, por ser
descentralizada e incontrolável, permite trocas de
igual para igual. Podemos dizer, assim, que
surgem, portanto, com a comunicação
informatizada, novos modelos cibernéticos de
avaliação cujas conexões favorecem controles
individuais e coletivos da construção de
conhecimentos (PRADO, 2013, pág. 228).

A presença de critérios de avaliação em 22 aulas (66,7\%), indica a preocupação do licenciando em fornecer informações sobre como mensurar o desempenho do aluno. 


\begin{tabular}{|c|c|}
\hline \multicolumn{2}{|r|}{ Avaliação } \\
\hline \multicolumn{2}{|c|}{ Você será avaliado de acordo segundo os critérios a seguir: } \\
\hline \multicolumn{2}{|c|}{ Atividade 1: Fórum "Epidemiologia e tuberculose" (Valor: $0-3,5$ ) } \\
\hline Pontuação & Critérios \\
\hline 1,0 & Contribuiu respondendo e justificando apenas 1 item. \\
\hline 2,0 & Contribuiu respondendo e justificando 2 itens. \\
\hline 3,0 & Contribuiu respondendo e justificando 3 itens. \\
\hline 3,5 & Contribuiu respondendo e justificando os 4 itens. \\
\hline \multicolumn{2}{|c|}{ Atividade 2: Linha do Tempo-Cruzadas (Valor: $0-1,5$ ) } \\
\hline Pontuação & Critérios \\
\hline 1,5 & Respondeu corretamente as cruzadas. \\
\hline \multicolumn{2}{|c|}{ Atividade 3: Desafio da UBSXXXI de outubro (Valor: $0-5,0$ ) } \\
\hline Pontuação & Critérios \\
\hline 1,0 & Apontou apenas 2 estratégia de controle e prevenção da dengue. \\
\hline 2,0 & Apontou 3 estratégias de de controle e prevenção da dengue. \\
\hline 3,0 & Apontou 4 estratégias de de controle e prevenção da dengue. \\
\hline 4,0 & $\begin{array}{l}\text { Apontou } 5 \text { estratégias de de controle e prevenção da dengue, } \\
\text { criando meios para divulgar à comunidade local. }\end{array}$ \\
\hline 5,0 & $\begin{array}{l}\text { Apontou } 6 \text { estratégias de de controle e prevenção da dengue, } \\
\text { criando meios para divulgar à comunidade local. }\end{array}$ \\
\hline
\end{tabular}

Figura 19: Critérios de avaliação de aula virtual 17.

A aula 17 surge como exemplo da capacidade do licenciando em propor modelos de avaliação. Os critérios foram aplicados através do fórum, palavras-cruzadas e situação problema.

Dentro da perspectiva de avaliação em ambiente virtuais, existem diferentes aspectos a serem analisados. Alguns licenciandos sugeriram a autoavaliação do aluno, outros a avaliação do design instrucional da própria aula virtual e a maioria se dedicou a tentar mensurar o desempenho do aluno frente ao conteúdo apresentado. Com a intenção de acompanhar o processo de aprendizagem dos estudantes, algumas formas de avaliação foram propostas como resumo de leituras e submissão de tarefas.

A proposta para a avaliação da própria aula virtual, foi feita pelos licenciandos em 26 unidades (78,8\%). Essa elevada taxa de 
utilização reafirma a importância de uma avaliação contínua como estratégia para a melhoria do design instrucional da aula.

(...) os alunos e suas avaliações não devem ser os únicos objetos da avaliação escolar se a concepção que se tem de avaliação atender tanto a função formativa quanto somativa, oferecendo informações relevantes para o planejamento ou aprimoramento do design instrucional contextualizado. Do mesmo modo, os resultados ou impactos não devem ser o único fator a ser examinado durante a avaliação de um programa, projeto ou qualquer outro objeto de avaliação dentro da educação. (PICONEZ, s.d, pág. 17)

\subsection{POTENCIALIDADES E FRAGILIDADES DA FORMAÇÃO DOCENTE}

Ao buscar responder o objetivo desta pesquisa, outros aspectos da formação docente em enfermagem tornaram-se evidentes e geraram inquietação: as potencialidades e também as lacunas na formação do licenciando.

As potencialidades apresentadas pelos licenciandos no decorrer da análise das aulas virtuais foram demonstradas através da habilidade no uso da tecnologia, a criatividade na proposição de materiais educacionais inovadores e o discernimento no uso de diferentes ferramentas que permitiram interação entre os sujeitos.

Dessa maneira, a competência tecnológica demonstrou agregar valor significante à qualidade da formação docente do enfermeiro.

Atualmente, para as organizações de saúde os profissionais devem ser cada vez mais qualificados, dinâmicos e atualizados. O desenvolvimento da competência tecnológica pode minimizar distâncias entre o ensino e o trabalho, pela possibilidade de se investir na formação e na educação permanente destes enfermeiros. (KOBAYASHI; LEITE, 2010) 
Entretanto, o projeto também evidenciou as lacunas da formação docente. Através da análise dos dados encontrados no item formulação de objetivos, dificuldade no ajuste a carga horária, critérios de escolha de ferramentas para auxiliar na avaliação da atividade educativa.

A preocupação se faz presente à medida que a análise demonstrou a ausência de instrumentos importantes da prática docente. A deficiência em propor objetivos educacionais, um requisito primordial do docente, atingiu a totalidade dos licenciandos. Assim como a dificuldade em ajustar a quantidade de conteúdo à carga horária pré-determinada e o uso incipiente do plano de aula.

Fica evidente que essas fragilidades permeiam o ensino em saúde como um todo e não somente na vertente da tecnologia educacional. 
6 CONCLUSÕES 


\section{CONCLUSÕES}

Tornando a abordagem mais ampla, os licenciandos foram estimulados a, através da atividade prática de produzir uma aula virtual, resgatar conceitos pedagógicos e também experiências educativas. Portanto, a construção de cada aula virtual por parte do licenciando, necessariamente, permitiu o exercício da competência tecnológica do futuro docente de enfermagem, bem como sua criatividade e capacidade de inovação.

O uso do design instrucional como referencial teórico possibilitou a construção das matrizes o que foi um ponto determinante para visualizar a construção dos licenciandos em uma esfera mais ampla.

A matriz de design instrucional funcionou como guia no caminho a ser percorrido para a compreensão da atividade educativa proposta, levantando potencialidades e dificuldades, sendo essencial para o alcance do objetivo proposto nesta pesquisa.

A ação pedagógica no ambiente virtual mostra-se complexa e por meio dos pontos evidenciados nesta pesquisa, respondo ao meu questionamento inicial afirmando que o licenciando em enfermagem deste estudo foi capaz de, através da utilização de conhecimentos prévios construídos no curso, produzir uma aula virtual criativa, adequada ao AVA e à educação profissional técnica de nível médio em enfermagem.

Através dos resultados obtidos evidencia-se que o conteúdo produzido nessa disciplina é de uma diversidade e riqueza inigualável por se tratar de material educacional produzido por educadores em formação e embasado na tecnologia.

Considero que a experiência da construção das aulas virtuais pelos 33 licenciandos que cursaram essa disciplina será de grande valia para a sua prática profissional e que independente de suas 
concepções pedagógicas ou áreas de interesse dentro do ensino em enfermagem, terão a consciência de que o uso de tecnologias no ensino é uma realidade sobre a qual eles tem condições de manejar e implementar em sua prática profissional como docente. 
7 CONSIDERAÇÕES FINAIS 


\section{CONSIDERAÇÕES FINAIS}

A permanente reflexão da prática pedagógica aliada à busca pelo aperfeiçoamento no uso de tecnologias no ensino em enfermagem fortalece a formação de qualidade do futuro docente de enfermagem, com a mente aberta a novos desafios, disposto e preparado para lidar com as dificuldades do cenário atual do ensino em enfermagem.

É necessário inovar ao instrumentalizar docentes no uso de tecnologias, para que estas efetivamente impactem na qualidade do ensino e da aprendizagem em enfermagem.

Como continuidade desta pesquisa, é possível vislumbrar um momento de grande desafio onde as aulas virtuais seriam implementadas na educação profissional técnica de nível médio em enfermagem. Os licenciandos então estariam sujeitos ao processo de mediar, mobilizar e avaliar o desempenho dos alunos, bem como a própria aula virtual produzida no AVA, todas as fases do design instrucional se fariam presentes na experiência da licenciatura. 
“Ensinar não é transferir conhecimento, mas criar as possibilidades para a sua própria produção ou a sua construção." (Paulo Freire) 
REFERÊNCIAS BIBLIOGRÁFICAS 


\section{REFERÊNCIAS BIBLIOGRÁFICAS}

ALMEIDA, DM. Construção e avaliação de aulas virtuais na formação de professores de enfermagem. 2013. 133p. Dissertação (Mestrado em Enfermagem) - Escola de Enfermagem, Universidade de São Paulo, São Paulo, 2013.

ALMEIDA, MEB. Educação a distância na internet: abordagens e contribuições dos ambientes digitais de aprendizagem. Educação e Pesquisa, São Paulo, v.29, n.2, dez. $2003 . \quad$ Disponível em http://www.scielo.br/pdf/ep/v29n2/a10v29n2.pdf. Último acesso em 06/11/2012.

ALVES, L; BARROS, D; OKADA, A. (Org.) MOODLE: Estratégias Pedagógicas e Estudos de Caso. Salvador: EDUNEB, 2009.

ANASTASIOU, LGC. Saberes pedagógicos e saberes científicos: Anotações acerca da formação inicial do licenciado e do bacharel. In: PRADO,C; PERES, HHC; LETE, MMJ (Org). Tecnologia da Informação e da comunicação em enfermagem. São Paulo: Editora Atheneu, 2011.

APPOLINÁRIO, F. Metodologia da ciência: filosofia e prática de pesquisa. São Paulo: Pioneira, 2006.

BATISTA, $\mathrm{N}$ et al. O enfoque problematizador na formação de profissionais da saúde. Rev. Saúde Pública, São Paulo, v. 39, n. 2, Abril 2005.2 Disponível em <http://www.scielo.br/scielo.php?script=sci_arttext\&pid=S0034$89102005000200014 \&$ Ing=en\&nrm=iso>. Último acesso em $17 \mathrm{fev}$ 2013.

BLOOM, BS. Taxonomia dos objetivos educacionais: domínio cognitivo. Porto Alegre: Globo, 1973.

COGO, ANP; SILVEIRA, DT; CATALAN, VM. Objetos de aprendizagem digitais como ferramenta de apoio na educação em enfermagem. [resumo]. In: Anais $X$ Congresso Brasileiro de Informática em Saúde. Florianópolis; 2006; p. 368-9.

COREN - CONSELHO REGIONAL DE ENFERMAGEM DE SÃO PAULO. Licenciatura plena é exigida para docentes de cursos técnicos de enfermagem. São Paulo: Janeiro, 2008. Acesso disponível em: http://coren-sp.gov.br/node/32313. Último acesso em fev., 2014. 
COSTA, PB et al. Fluência digital e uso de ambientes virtuais: caracterização de alunos de enfermagem. Rev. esc. enferm. USP [online]. 2011, vol.45, n.spe, pp. 1589-1594.

DEWEY, J. Experience and Education. New York: The Macmillan company, 1938.

EEUSP - Escola de Enfermagem da USP. Projeto PolíticoPedagógico Licenciatura em Enfermagem. Março, 2013. Acesso disponível

em

http://www.ee.usp.br/ensino/graduacao/Projeto\%20Politico\%20Peda g\%C3\%B3gico/Projeto_Pol\%C3\%ADtico_Pedagogico_do_Curso_de _Licenciatura_em_Enfermagem.PDF.

FACHIN, O. Fundamentos de Metodologia. $5^{a}$ Ed. [ver]. São Paulo: Saraiva, 2006.

FARIA, NGF. Fotografia digital de feridas: desenvolvimento e avaliação de curso online para enfermeiros. Dissertação (Mestrado). São Paulo: Escola de Enfermagem da Universidade de São Paulo; 2010.

FERRAZ, APCM; BELHOT, RV. Taxonomia de Bloom: revisão teórica e apresentação das adequações do instrumento para definição de objetivos instrucionais. Gest. Prod., São Carlos, v. 17, n. 2, $2010 . \quad$ Disponível em <http://www.scielo.br/scielo.php?script=sci_arttext\&pid=S0104$530 X 2010000200015 \& \operatorname{lng}=e n \& n r m=i s o>$. Último acesso em 18 Nov. 2013.

FILATRO, AC. Design instrucional contextualizado: educação e tecnologia. São Paulo: Ed. Senac, 2004.

Person Education do Brasil, 2008.

Design Instrucional na prática. São Paulo:

FILATRO, AC; PICONEZ, SCB. Design instrucional contextualizado. XI Congresso Internacional de Educação a Distância, Salvador, 2004.

FREIRE, P. Pedagogia do oprimido. 17Ed. Rio de Janeiro: $\mathrm{Paz}$ e Terra. Acesso disponível em http://portal.mda.gov.br/portal/saf/arquivos/view/ater/livros/Pedagogia _do_Oprimido.pdf. Último acesso em 27/10/2012.

HAIDT, RCC. Curso de didática geral. São Paulo: Ed. Ática, $7^{\circ} \mathrm{Ed}, 2002$.

HEIMANN, C. Capacitação pedagógica de docentes de enfermagem: desenvolvimento e avaliação de um curso à distância. 
2012. 157f. Dissertação (Mestrado em Enfermagem) - Escola de Enfermagem, Universidade de São Paulo, São Paulo, 2012.

JOU, GI; SPERB, TM. A metacognição como estratégia reguladora da aprendizagem. Psicologia Reflexão Crítica, 19, 2, 177 185, 2006.

KOBAYASHI, RM; MARTINS, CP. Tecnologia da informação e da comunicação em serviço: competências dos enfermeiros. In: PRADO,C; PERES, HHC; LETE, MMJ (Org). Tecnologia da Informação e da comunicação em enfermagem. São Paulo: Editora Atheneu, 2011.Pag. 24.

KOBAYASHI, RM; LEITE, MMJ. Desenvolvendo competências profissionais dos enfermeiros em serviço. Revista Brasileira de Enfermagem, Brasília, v. 63, n. 2, Abril, 2010. Disponível em <http://www.scielo.br/scielo.php?script=sci_arttext\&pid=S003471672010000200012\&lng=en\&nrm=iso>. Último acesso em 10/06/2013.

KRATOCHWILL, S; SILVA, M. Avaliação da aprendizagem on-line: contribuições especificas da interface fórum. Rev. Diálogo Educ., Curitiba, v. 8, n. 24, p. 445-458, maio/ago, 2008.

LIBÂNEO, JC. Adeus professor, adeus professora? Novas exigências educacionais e profissão docente. 6 ed. São Paulo: Cortez, 2002. (Coleção questões da nossa época, v. 67).

MAISSIAT, GS; CARRENO, I. Enfermeiros docentes do ensino técnico em enfermagem: Uma revisão integrativa. Revista Destaques Acadêmicos: CCBS/UNIVATES, ANO 2, N. 3, 2010.

MATTAR, J. Youtube na educação: o uso de vídeos em Ead. In: Anais do $15^{\circ}$ Congresso Internacional Associação Brasileira de Educação a Distância; 2009 set. 27-30; Fortaleza [internet]. Fortaleza: ABED; 2009. [citado 2009 nov. 19]. Disponível em: http://www.abed.org.br/congresso2009/CD/trabalhos/246200919073 3.pdf.

MOODLE. Estatísticas do site. Acesso em https://moodle.org/stats. Último acesso em 27/10/2012.

MORAN, JM. Ensino e aprendizagem inovadores com tecnologias audiovisuais e telemáticas. In: Moran JM, Maseto MT, Behrens MA. Novas tecnologias e mediação pedagógica. Campinas, SP: Papirus; 2000. p. 11-65.

MORAN, JM. Contribuições para uma pedagogia da educação online. In: SILVA, M. (Org). Educação online. São Paulo: Loyola. 2003. Pág. 39-50. 
NEVES, CMC. Critérios de qualidade para a educação à distância. Tec Educ 1998; 26 (141): 13-7.

OLIVEIRA, MC. Plano de aula: ferramenta pedagógica da prática docente. Pergaminho. Patos de Minas: UNIPAM, (2): 121129, nov. 2011.

PALLOFF, RM; PRATT, K. O aluno virtual: um guia para trabalhar com estudantes on-line. Trad. Vinícius Figueira. Porto Alegre: Artmed, 2004.

PARRA Filho, D; SANTOS, JA. Metodologia cientifica. São Paulo: Futura; 1998.

PENA, GAC. Formação docente e aprendizagem da docência: um olhar sobre a educação profissional. Viçosa: Educação em Perspectiva, v. 2, n. 1, p. 98-118, jan./jun. 2011.

PEREIRA, DG; RESENDE, MR. Percepção dos professores sobre a mediação no curso de licenciatura em matemática à distância. Revista Encontro de Pesquisa em Educação. v. 1, n. 1, p. 65-79, outubro. 2013.

PERES, HHC; LEITE, MMJ . Software educacional: objetivos educacionais. Versão II [CD-ROM]. São Paulo: EEUSP; 2000.

PERRENOUD, P. Práticas pedagógicas, profissão docente e formação: perspectivas sociológicas. Lisboa: Dom Quixote, 1993.

Construir as competências desde a escola. Tradução Bruno Magne. Porto Alegre: Artes Médicas sul, 1999.

PERRENOUD, P; THURLER, MG; MACHADO, NJ; ALLESSANDRINI, CD. As competências para ensinar no século XXI: A formação dos professores e o desafio da avaliação.trad. Cláudia Schilling e Fátima Murad - Porto Alegre: Artmed Editora, 2002.

PICONEZ, SCB. A avaliação como prática pedagógica de aprendizagem permanente. Faculdade de Educação - Universidade de São Paulo, s.d.

PICONEZ, SCB; FILATRO, AC. O desenvolvimento profissional da docência na formação de professores face a utilização das tecnologias. Educação Temática Digital, Campinas, v.10, n.2, p.394-427, jun. 2009.

POLIT, DF; HUNGLER, BP. Fundamentos de pesquisa em enfermagem. $3^{\mathrm{a}}$ ed. Porto Alegre: Artes Médicas; 1995.

PRADO, C. Tecnologias digitais no curso de licenciatura em enfermagem: uma inovação no processo ensino-aprendizagem. São 
Paulo, 2013. Tese (Livre-docência) - Escola de Enfermagem de São Paulo. Universidade de São Paulo.

PRADO, C. (org.) Práticas pedagógicas em enfermagem: processo de reconstrução permanente. $1^{\text {a }}$ ed. São Caetano do Sul: Difusão Editora, 2013.

PRADO,C; PERES, HHC; LEITE, MMJ (Org). Tecnologia da Informação e da comunicação em enfermagem. São Paulo: Editora Atheneu, 2011.

PRADO, C; VAZ, DR; ALMEIDA, DM. Teoria da aprendizagem significativa: elaboração e avaliação de aula virtual na plataforma Moodle. Rev. bras. enferm., Brasília , v. 64, n. 6, Dez. 2011 . Disponível em <http://www.scielo.br/scielo.php?script=sci_arttext\&pid=S0034$71672011000600019 \&$ Ing=en\&nrm=iso>. Último acesso em 06 Fev. 2014.

PULINO FILHO, AR. Introdução ao Moodle (1.6.5+). Creative Commons, 2007. Acesso disponível em http://portal.virtual.ufpb.br/biblioteca-

virtual/files/pub_1291078165.pdf. Último acesso em 27/10/2012.

RODRIGUES, RCV. Ambiente virtual de aprendizagem em reanimação cardiorrespiratória em neonatologia. São Paulo, 2008. Dissertação (Mestrado) - Escola de Enfermagem de São Paulo. Universidade de São Paulo.

RODRIGUES, RCV; PERES, HHC. Panorama brasileiro do ensino de Enfermagem On-line. Rev Esc Enferm USP; 42(2): 298304, jun. 2008.

SANTOS, EO. Articulação de saberes na EAD online: por uma rede interdisciplinar e interativa de conhecimentos em ambientes virtuais de aprendizagem. In: Silva $\mathrm{M}$, organizador. Educação online. $2^{a}$ ed. São Paulo: Loyola; 2006. p. 219-32.

SÃO PAULO (Estado). Secretaria da Saúde. Curso técnico de nível médio em enfermagem: módulo de habilitação: guia metodológico de apoio ao docente. São Paulo, 2009.

SILVA, EL; MENEZES, EM. Metodologia da Pesquisa e Elaboração de Dissertação. 3ª Ed. UFSC, 2001.

SILVA, M. (Org). Educação online. São Paulo: Loyola. 2003.

SOLIGO, R. Dez importantes questões a considerar: Variáveis que interferem nos resultados do trabalho pedagógico. Revista Nova escola, n. 256, Outubro, 2012. Acesso disponível em 
http://revistaescola.abril.com.br/pdf/dez-importantes-questoesrosaura-soligo.pdf. Último acesso em 04 fevereiro de 2014.

TANAKA, RY et al. Objeto educacional digital: avaliação da ferramenta para prática de ensino em enfermagem. Acta paul. enferm. [online]. 2010, vol.23, n.5, pp. 603-607.

TORREZZAN, CAW. Design pedagógico: um olhar na construção de materiais educacionais digitais. Porto Alegre (dissertação de mestrado em educação), UFRGS, 2009.

VALENTE, GSC. A reflexividade na prática docente da graduação em enfermagem: nexos com a formação permante do enfermeiro professor. Rio de janeiro (tese de doutorado em enfermagem), UFRJ, 2009.

VALENTE, GSC; VIANA, LO. A formação do enfermeiro para o ensino de nível médio em enfermagem: Uma questão de competência. Revista Eletrônica Enfermeria Global, n. 9, nov. 2006.

VASCONCELLOS, CS. Metodologia Dialética em Sala de Aula. In: Revista de Educação AEC. Brasília: abril de 1992 (n. 83).

Construção do conhecimento em sala de aula. $17^{\text {a }}$ Ed. São Paulo: Libertad, 2005.

Webquest.org [internet]. San Diego State University. Dodge B. What is a WebQuest? Último acesso em 09 jan 2014. Disponível em: http://webquest.org/index.php.

WILEY, D. A. Conecting learning objects to instructional theory: A definition, a methaphor and a taxonomy. The Instructional Use of Learning Objets. Wiley, D. (Ed.) 2001. Disponível em: www.reusabilility.org/read/chapters/wiley.doc. 2001. Acesso em 30/01/2014.

ZANOTTO, MAC; ROSE, TMS. Problematizar a própria realidade: análise de uma perspectiva de formação contínua. Educação e Pesquisa, São Paulo, v.29, n.1, 45-54, jan./jun. 2003. 
APÊNDICES 


\title{
APÊNDICE A \\ ORIENTAÇÕES PARA A ELABORAÇÃO DA AULA VIRTUAL \\ ELABORAÇÃO DAS AULAS VIRTUAIS
}

\begin{abstract}
$2^{\circ}$. SEMESTRE - 2012
As transformações que se fazem presente nos diversos campos da sociedade, em conjunto com o desenvolvimento tecnológico exigem da escola e do professor novas posturas e a necessidade da incorporação dos avanços tecnológicos nas áreas de comunicação e informação à prática educativa. $O$ domínio das linguagens utilizadas pelas tecnologias pode levar o docente, juntamente com os alunos, a descobrir novas formas de aprender e ensinar, a partir de um processo colaborativo.
\end{abstract}

Em seu livro - 10 novas competências para ensinar - Perrenoud aponta como uma das competências necessárias para ensinar na atualidade a utilização das novas tecnologias expressa através da utilização de editores de texto, a exploração das potencialidades didáticas dos programas em relação aos objetivos do ensino, a comunicação à distância por meio da telemática e a utilização das ferramentas multimídia no ensino.

Pesquisas demonstram que professores não preparados para o uso das tecnologias em sua formação acadêmica se sentem desencorajados a utilizá-las em suas aulas e àqueles que tiveram esse preparo têm maior facilidade de incorporá-las a sua prática docente.

Assim, o planejamento e desenvolvimento da aula virtual busca o desenvolvimento dessa competência tecnológica e visa à formação do futuro enfermeiro e docente de enfermagem, de forma crítica e 
reflexiva, tendo como um dos componentes de seu perfil a perspectiva de buscar e utilizar novos conhecimentos e recursos tecnológicos no desenvolvimento de sua prática profissional.

Para realizar essa atividade você precisará:

- Escolher uma das aulas ministradas por você no Curso de Licenciatura.

- Construir, a partir desse conteúdo teórico, sua aula virtual.

- Organizar a aula através de uma rota de aprendizagem.

- Como requisitos mínimos a aula deverá conter: objetivos, critérios de avaliação, um objeto virtual de aprendizagem, uma ou mais atividades para nota e bibliografia de apoio.

- Enviar a rota de aprendizagem, os arquivos, objetos de aprendizagem e links para Vanessa (vanessa.lopes.munhoz@usp.br) até o dia 22 de Outubro.

- A aula será disponibilizada no Moodle pela Vanessa.

- Apresentar a estrutura da aula no dia 01 de Novembro.

Obs: Para que você possa escolher ferramentas do Moodle para utilizar na aula disponibilizamos um tutorial sobre o mesmo explicando as ferramentas disponíveis.

Qualquer dúvida entre em contato com Denise ou Vanessa.

Bom trabalho!!!! 


\section{APÊNDICE B}

\section{CRITÉRIOS DE AVALIAÇÃO DA AULA VIRTUAL}

\section{*CRITÉRIOS DE AVALIAÇÃo DA AULA VIRTUAL PARA A NOTA DO ALUNO NA DISCIPLINA ENO336}

Público-alvo da aula virtual: Estudantes de educação profissional técnica de nível médio.

Duração da aula: 4 horas

Aluno:

\begin{tabular}{|c|c|}
\hline INDICADORES & $\begin{array}{l}\text { NOTA } \\
\text { (até } 1,0 \text { cada } \\
\text { item) }\end{array}$ \\
\hline 1. Objetivos: claros e podem ser alcançados? & \\
\hline $\begin{array}{l}\text { 2. Conteúdos: adequados quanti e qualitativamente para o público- } \\
\text { alvo? }\end{array}$ & \\
\hline 3. Estratégias de ensino: eficazes para a apreensão dos conteúdos? & \\
\hline $\begin{array}{l}\text { 4. Atividades de aprendizagem: favorecem o alcance dos objetivos da } \\
\text { aula? }\end{array}$ & \\
\hline $\begin{array}{l}\text { 5. Equilíbrio entre atividades individuais e coletivas: as atividades } \\
\text { propostas contribuem para o aprendizado individual e coletivo? }\end{array}$ & \\
\hline $\begin{array}{l}\text { 6. Pertinência das referências bibliográficas: coerentes com o } \\
\text { conteúdo e atualizadas? }\end{array}$ & \\
\hline $\begin{array}{l}\text { 7. Carga horária da aula em relação às atividades propostas: } \mathrm{A} \text { CH } \\
\text { estipulada para cumprimento das atividades e estudo está } \\
\text { adequada? }\end{array}$ & \\
\hline $\begin{array}{l}\text { 8. Qualidade dos recursos audiovisuais: São de boa qualidade } \\
\text { técnica os recursos no ambiente (figuras, fotos, animação, som e } \\
\text { links)? }\end{array}$ & \\
\hline $\begin{array}{l}\text { 9. Interatividade do ambiente: A aula possibilita a interatividade do } \\
\text { aluno com outros alunos e com o professor? }\end{array}$ & \\
\hline $\begin{array}{l}\text { 10. Avaliação da aprendizagem: Os critérios da avaliação estão bem } \\
\text { distribuídos? }\end{array}$ & \\
\hline TOTAL & \\
\hline
\end{tabular}


ANEXO 


\section{ANEXO A \\ PARECER CONSUBSTANCIADO DO CEP}

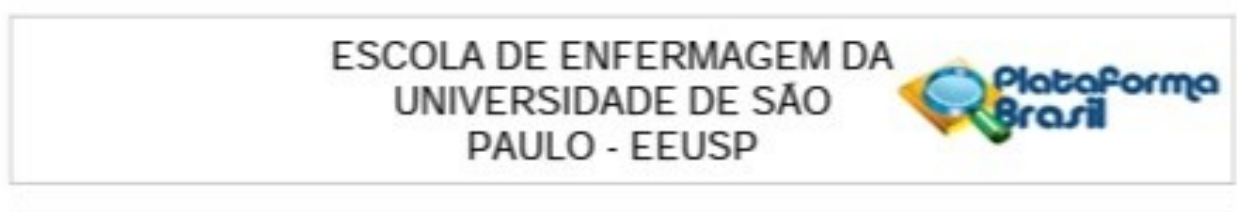

\section{PARECER CONSUBSTANCIADO DO CEP}

\section{DADOS DO PROJETO DE PESQUISA}

Titulo da Pesquisa: AVALIAÇAO DE AULAS VIRTUAIS NO CURSO DE LICENCIATURA EM ENFERMAGEM: OS ESTUDANTES COMO AUTORES

Pesquisador: Vanessa Lopes Munhoz Afonso

Area Tematica:

Versao: 1

CAAE: 18557713.8 .0000 .5392

Instituiçao Proponente: Escola de Enfermagem da Universidade de Sao Paulo - EEUSP

Patrocinador Principal: Financiamento Proprio

\section{DADOS DO PARECER}

Numero do Parecer: 403.389

Data da Relatoria: 17/09/2013

\section{Apresentaçao do Projeto:}

A educaçáo tem vivenciado um momento historico de transiçao, devido a mudanças sociais e novas descobertas tecnologicas que acontecem a todo instante nas diferentes areas de conhecimento. Essas transformaçoes refletem diretamente nos processos de trabalho, exigindo o desenvolvimento de habilidades metacognitivas e de competencias para aprender cooperativamente, apoiadas em conteudos contextualizados e na experiencia individual. Os atuais metodos de ensino valorizam a troca de informaçoes entre aluno e professor ao inves da transmissao unidirecional de informaçào. Baseado no percurso educacional que e escolhido, as propostas educacionais interferem diretamente na motivaçao do sujeito ao se mobilizar para o aprendizado e na disponibilidade que ele demonstrara a experiencias futuras. Experiencias positivas e interativas tem uma maior capacidade de instituir condiçoes e estimular competencias para experiencias futuras.

Refletindo a respeito da pratica docente, o educador nao tem que estar somente atento ao principio geral de que as condiçoes do meio modelam o aprendizado do aluno, mas tambern reconhecer que nas situaçoes concretas, as circunstancias conduzem a experiencias que produzem o conhecimento. Notamos entao a pratica reflexiva como postura fundamental para quem tem a missao de ensinar. A educaçao online, compreendida dentro da educaçao a distancia (EaD), se

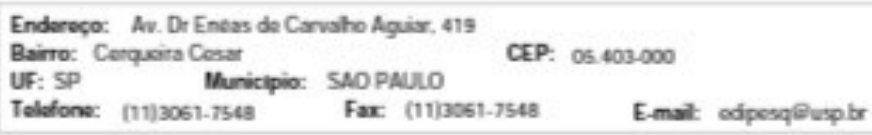




\section{ESCOLA DE ENFERMAGEM DA UNIVERSIDADE DE SAO PAULO - EEUSP}

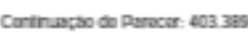

descortina como um passo alem. Emergem grandes incentivos ao uso da interatividade da internet na aprendizagem e tornam-se obsoletos modelos de transmissao de conhecimento unidirecionais. Frente a essas novas demandas, a utilizaçao das tecnologias como instrumento no processo ensino e aprendizado vem ao encontro desses novos paradigmas e surge de maneira expressiva nas instituiçoes de ensino superior.O artigo 80 das disposiçoes gerais da Lei de Diretrizes e Bases da Educaçao (LBD), n9394/96 refere-se a educaçao a distancia estabelecendo que o poder publico incentivara o desenvolvimento e a veiculaçao de programas de ensino a distancia, em todos os niveis e modalidades de ensino, e de educaçao continuada. Com a intençao de suprir algumas limitaçoes como o pouco dinamismo das interaçoes em classe e o incentivo a construçao do conhecimento individual e coletivo entre esses sujeitos, muitos cursos de graduaçao tem adotado o ambiente virtual de aprendizagem (AVA).

O uso de tecnologias na mais variadas areas do ensino em enfermagem demonstra potencial, desde recursos voltados ao ensino para a pratica assistencial, caracterizaçao dos discentes e dos ambientes virtuais utilizados bem como a busca por um ensino online de qualidade atraves do uso de diversas ferramentas.

Seus resultados comprovam que $100 \%$ dos pesquisados afirmaram algum conhecimento em informatica, sendo $26,51 \%$ em nivel intermediario. $100 \%$ dos licenciandos utilizam a internet e possuem e-mail, a grande maioria (92\%) informa utilizar diariamente tendo como principais locais de acesso a propria residencia (85\%) e a universidade (21\%).

Quanto aos aspectos de habilidade no uso de AVA e no interesse, 64,7\% utilizam frequentemente o Moodle (Modular Object-Oriented Dynamic Learning Environment) e 88,2\% gostariam de utiliza-ło durante sua formaçao. Citaram o armazenamento de conteudo das aulas, a otimizaçao do tempo, flexibilidade de acesso, e outros meios e ferramentas no processo ensino aprendizagem, saindo da monotonia do modelo tradicional.

A elevada porcentagem de utilizaçao do Moodle reflete a divulgaçao e o acesso a plataforma pela Universidade de Sao Paulo, cada vez mais presente no cotidiano dos docentes. Atualmente o Moodle e bastante conhecido entre estudantes e docentes. Teve um crescimento exponencial contando hoje com cerca de 62 milhoes de usuarios e presente em mais de 200 palses. (Site MOODLE, 2012).

Essa proposta privilegia a formaçao do docente em enfermagem de forma critica e reflexiva, tendo como um dos componentes de seu perfil a perspectiva de buscar e utilizar novos conhecimentos para o desenvolvimento da pratica profissional, especialmente no uso de tecnologias.

Dessa discussao emergem os seguintes questionamentos: $O$ licenciando e capaz de desvelar seus

Endereç: Av. Dr Entas de Canvaho Aguiar, 419
Bairro: Cenquara Cesar
UF: SP
Itunicipio: SAO PAULO

Teldone: (11)3061-75es Fax (11)3061-7548 E-msil odpesqliusple 


\section{ESCOLA DE ENFERMAGEM DA \\ UNIVERSIDADE DE SAO \\ PAULO - EEUSP}

Curthacaso de Derscar: 603399

conhecimentos e articula-los em uma aula virtual? Essa geraçao de alunos digitais e capaz de inovar na construçao de uma aula?

\section{Objetivo da Pesquisa:}

Descrever e avaliar aulas virtuais construldas por licenciandos de enfermagem.

\section{Avaliaçao dos Riscos e Beneficios:}

Riscos - nenhum

Beneficios - compreender a capacidade do aluno aprender em aulas virtuais

\section{Comentarios e Consideraçoes sobre a Pesquisa:}

Trata-se de uma pesquisa exploratorio-descritiva, do tipo documental e na perspectiva quantitativa.

O estudo sera desenvolvido na Escola de Enfermagem da Universidade de Sao Paulo (EEUSP), no curso de Licenciatura em Enfermagem, disciplina Seminarios de Educaçao: Vivenciando o Processo de Educaçao na Enfermagem (ENO 336), oferecida pelo Departamento de Orientaçao Profissional.

Possui carga horaria total de 30 horas e e realizada semestralmente, ocorre concomitante com a ultima disciplina do curso de licenciatura, ENO 436 ¿ Metodologia do Ensino em Enfermagem II.

Para confrontar os objetivos pretendidos e os alcançados, as aulas virtuais serao analisadas segundo o modelo do Design Instrucional Contextualizado (DIC).

$\mathrm{O}$ design de unidades de aprendizagem e utilizado neste projeto atraves da construçao de matrizes para cada aula virtual do licenciando, portanto, serao construldas 33 matrizes individuais. Por meio da matriz teremos uma visao panoramica de cada unidade de aprendizagem, bem como de suas potencialidades ou fragilidades.

Para que 0 aluno da licenciatura da EEUSP seja bem sucedido na construçao da aula virtual, espera-se que ele utilize conhecimentos previos construidos ao longo do curso, seja capaz de organizar e planejar o conteudo de forma criativa, adequar o tema da aula para o poblico alvo e propor atividades que tornem possivel o acompanhamento do desempenho do aluno no ambiente virtual.

\section{Consideraçoes sobre os Termos de apresentaçao obrigatoria:}

As autoras solicitam dispensa de TCLE e afirmam que trata-se de uma pesquisa documental e que os dados, obtidos da plataforma Moodle, realizados pelos alunos de licenciatura sao passiveis de serem utilizados pois os alunos recebem esta informaçao no inicio da disciplina.

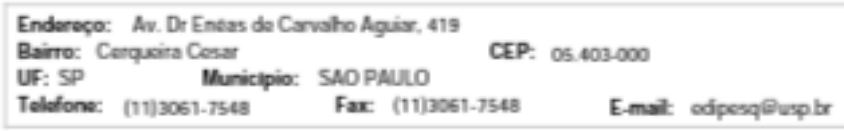




\section{ESCOLA DE ENFERMAGEM DA UNIVERSIDADE DE SAO \\ PAULO - EEUSP}

Cortinapas do Rersers: 403365

As autoras mostram-se muito cuidadosas no projeto e com os sujeitos de pesquisa dizendo que manterao o anonimato dos alunos e se necessario transcrever alguma informaçáo destes mudarao os nomes por letras e numeraçao.

\section{Recomendaçoes:}

O fato de se avisar os alunos que os dados da aula virtual podem ser utilizadas para pesquisa náo garante os aspectos eticos necessarios para a sua realizaçao, pois os estudantes podem se sentir sem liberdade para escreverem o que desejam, mesmo no ambiente virtual.

E desejavel que o TCLE seja aplicado aos estudantes. Em caso contrario, a utilizaçao das informaçoes devera ser autorizada pela Comissao de Graduaçao da Instituiçao de Ensino Superior.

Conclusoes ou Pendencias e Lista de Inadequaçoes:

O projeto nao apresenta obices eticos.

Situaçao do Parecer:

Aprovado

Necessita Apreciaçao da CONEP:

Nao

Consideraçoes Finais a criterio do CEP.

Este CEP informa a necessidade de registro dos resultados da pesquisa na Plataforma Brasil.

SAO PAULO, 23 de Setembro de 2013

Assinador por:
Celia Maria Sivalli Campos

(Coordenador)

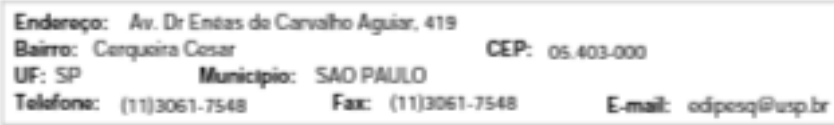

